UNIVERSIDADE DE SÃO PAULO

FACULDADE DE EDUCAÇÃO

THIAGO ALVES DE OLIVEIRA

\title{
A EDUCAÇÃO INTEGRAL NO SÉCULO XXI - DO PROGRAMA MAIS EDUCAÇÃO AO PROGRAMA NOVO MAIS EDUCAÇÃO
}




\section{A EDUCAÇÃO INTEGRAL NO SÉCULO XXI - DO PROGRAMA MAIS EDUCAÇÃO AO PROGRAMA NOVO MAIS EDUCAÇÃO}

Dissertação apresentada à Faculdade de Educação da Universidade de São Paulo para obtenção do título de mestre em educação

Área do conhecimento: Educação e Psicologia

Orientador: Profa. Dra. Sandra Maria Sawaya

São Paulo 
Autorizo a reprodução e divulgação total ou parcial deste trabalho, por qualquer meio convencional ou eletrônico, para fins de estudo e pesquisa, desde que citada a fonte.

Catalogação da Publicação

Ficha elaborada pelo Sistema de Geração Automática a partir de dados fornecidos pelo(a) autor(a) Bibliotecária da FE/USP: Nicolly Soares Leite - CRB-8/8204

Oliveira, Thiago Alves de

$$
\text { Educação Integral no século XXI - Do Programa }
$$

Mais Educação ao Programa Novo Mais Educação / Thiago

Alves de Oliveira; orientadora Sandra Maria Sawaya.

-- São Paulo, 2019.

$123 \mathrm{p}$.

Dissertação (Mestrado - Programa de Pós-Graduação Educação, Linguagem e Psicologia) -- Faculdade de Educação, Universidade de São Paulo, 2019.

1. Educação Integral. 2. Programa Mais Educação. 3. Programa Novo Mais Educação. 4. Organismos Internacionais. 5. Neoliberalismo. I. Sawaya, Sandra Maria, orient. II. Título. 
Nome: Thiago Alves de Oliveira

Título: Educação Integral no século XXI- Do programa Mais Educação ao Programa Novo Mais educação.

Dissertação apresentada à Faculdade de Educação da Universidade de São Paulo para obtenção do título de mestre em educação

Área do conhecimento: Psicologia e Educação

Aprovado em:

Banca Examinadora

Banca Examinadora

Prof. Dr.

Instituição

Assinatura

Prof. Dr.

Instituição Assinatura

Prof. Dr.

Instituição Assinatura 


\section{AGRADECIMENTOS}

Agradeço a minha orientadora Sandra Sawaya por sua disponibilidade, paciência e rigor. Agradeço por acreditar neste trabalho. Muito obrigado!

Agradeço aos professores Ellie Ghanen e Sonia Kruppa que em minha qualificação, com um olhar acurado, trouxeram valiosas contribuições.

Agradeço as professoras Marilene Proença a Jaqueline Kalmus que aceitaram prontamente a compor minha banca de defesa.

Agradeço aos companheiros do grupo de estudo, Fábio Jesus, Marina, Hanna, Luísa, Edna e Karina por me propiciarem ricos momentos de crescimento intelectual.

Agradeço meu companheiro, Guilherme Rios, por estar comigo toda essa empreitada, me motivando e pela paciência.

Agradeço aos meus pais Irene e Milton, que mesmo com pouca escolarização, sempre me ensinaram o valor da educação.

Agradeço aos meus irmãos Márcia e Márcio por serem mais que família, serem amigos.

Agradeço a Andreia Habyak e Andressa Habyak por serem mais que amigas, serem família.

Agradeço a Lívia Podda pela amizade e a ajuda na revisão deste trabalho.

Agradeço aos meus colegas de trabalho da EMEF Vicentina Ribeiro Luz, em especial à Maria Helena Correa Matei e Natália Lisboa, por compartilharem comigo as angústias e ansiedades da escola pública e da vida acadêmica.

Agradeço aos meus alunos que me fazem acreditar que mesmo diante de muitas adversidades a educação é possível.

Agradeço à faculdade de educação da USP. 
A árvore que não dá frutos é xingada de estéril. Quem examina o solo? O galho que quebra é xingado de podre, mas não havia neve sobre ele?

Do rio que tudo arrasta se diz que é violento, ninguém diz violentas as margens que o cerceiam

\section{Bertold Brecht}




\section{RESUMO}

\section{Oliveira, Thiago Alves de. A educação Integral no século XXI- Do Programa Mais}

Educação ao Programa Novo Mais Educação. 2019. 123f. Dissertação (Mestrado em

Educação) - Faculdade de Educação, Universidade de São Paulo, 2019.

Esta dissertação tem por objetivo apresentar resultados e conclusões da pesquisa intitulada: A Educação Integral no século XXI - Do Programa Mais Educação ao Programa Novo Mais Educação. A pesquisa constitui-se de um estudo descritivo analítico e desenvolveuse a partir da análise documental da legislação brasileira e outros textos que subsidiaram o Programa Mais Educação Federal e o Programa Novo Mais Educação Federal como políticas públicas. Nosso objetivo tentou compreender as propostas de educação integral apregoadas nos textos oficiais. Além disso, procuramos investigar o diálogo e/ou a resistência desses programas às concepções de educação disseminadas pelos reformadores da educação: Organismos Internacionais e empresariado. Este trabalho compreende o Programa Mais Educação como uma política pública contraditória, fruto do momento histórico e político que se desencadeou com os governos petistas (2002-2016). O período foi marcado por uma tentativa de conciliação entre os interesses das classes trabalhadoras e as aspirações da burguesia nacional e do grande capital. Diante do exposto, o programa apresentava uma real proposta de educação integral como formação de um ser em sua integralidade em seus diversos aspectos como humano e, ao mesmo tempo, conciliava-se com os interesses e consensos disseminados pelos reformadores neoliberais da educação.

Palavras-chave: Educação Integral; Programa Mais Educação; Programa Novo Mais Educação; Organismos Internacionais; Neoliberalismo. 


\begin{abstract}
Oliveira, Thiago Alves de. A educação Integral no século XXI- Do Programa Mais

Educação ao Programa Novo Mais Educação. 2019. 123f. Dissertação (Mestrado em

Educação) - Faculdade de Educação, Universidade de São Paulo, 2019.

This thesis aims to present results and conclusions regarding the research entitled: $A$ Educação Integral no século XXI - Do Programa Mais Educação ao Programa Novo Mais Educação. The research constitutes of an analitical and descriptive study, and has developed from the documentary analyis from the brazilian legislation and other texts that have assisted the Programa Mais Educação Federal e o Programa Novo Mais Educação Federal as public policy. Our objective tried to understand the integral education proposals proclaimed in the oficial texts. Besides this, we tried to investigate the dialog and/or the resistence from these programs through the education conceptions widespread by education reformers: International Organisms and business community. This research understands the Programa Mais Educação as a contraditory public policy, product from a political and historical moment wich came from left wing governments (PT party) (2002-2016). This period was marked by an attemptive of conciliation between the working classes and the aspirations of the middle class and from the big business. Based on the above, the program presented a real proposal of integral education as formation of a being in its totality and aspects as human and, at the same time, harmonized with interests and consences widespread by neoliberals education reformers.
\end{abstract}

Key Words: Integral Education; Programa Mais Educação; Programa Novo Mais Educação; International Organisms; Neoliberalism. 


\section{Sumário}

1 INTRODUÇÃO

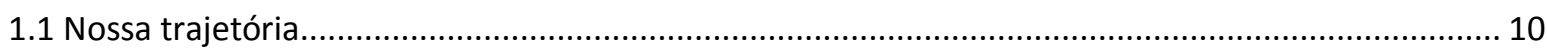

1.2 Um primeiro olhar para a educação no Brasil ..................................................................... 12

1.3 Educação integral, Educação em tempo integral e Educação integrada........................................ 15

2 O MAIS EDUCAÇÃO COMO PROBLEMA DE PESQUISA ............................. 21

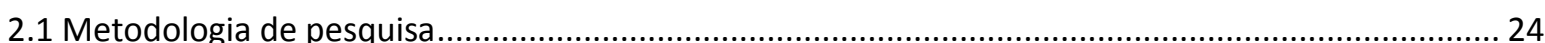

\section{A EDUCAÇÃO INTEGRAL NO SÉCULO XX: UM PASSEIO PELA HISTÓRIA}

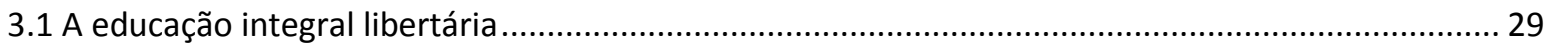

3.2 A educação integral conservadora- A década de 30 e a Ação Integralista Brasileira....................... 32

3.3 A educação integral e a constituição da república liberal .......................................................... 34

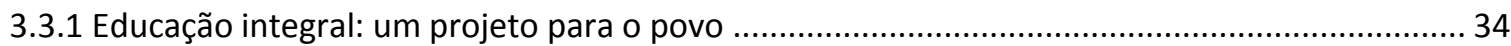

3.3.2 A escola nova e o surgimento de um modelo de Educação Integral ........................................39

3.3.3 Os centros educacionais carneiro ribeiro: uma experiência grandiosa para poucos ................. 44

3.3.4 Os centros Integrados de Educação Pública (CIEPS) ........................................................ 47

\section{A EDUCAÇÃO E SEUS REFORMADORES: A ERA DO NEOLIBERALISMO E SEUS DESDOBRAMENTOS PARA A EDUCAÇÃO

4.1 A reorganização do capitalismo

4.2 Os organismos internacionais e a educação: um projeto para as competências e para a "solução" da pobreza

4.3 As pedagogias do aprender a aprender e da educação ao longo da vida para a formação do neossujeito

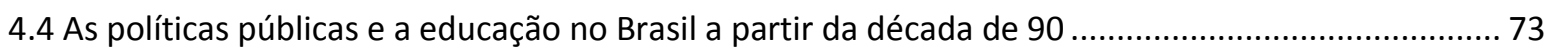

4.5 Os governos petistas e o empresariado nas políticas em educação ................................................ 78

4.5.1 A ação do empresariado na educação brasileira e a formulação do PDE. 82

5 O PROGRAMA MAIS EDUCAÇÃO E NOSSAS ANÁLISES 88

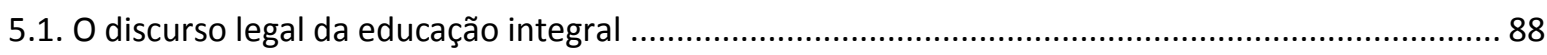

5.2 Conceitos e fundamentações do Programa Mais Educação....................................................... 92

5.3 Gestão e financiamento do Programa Mais Educação ........................................................ 95

5.4 os reformadores e o Programa Novo Mais Educação.............................................................. 102

6 REFERÊNCIAS BIBLIOGRÁFICAS ...................................................................... 115 


\section{INTRODUÇÃO}

\subsection{Nossa trajetória}

Nossa trajetória de pesquisa tem início na graduação. Ao cursar a disciplina de psicologia da educação, na FEUSP, fomos tomados por um encantamento e, ao mesmo tempo, por um sentimento de indignação perante as questões educacionais, principalmente aquelas que envolvem diretamente as classes desfavorecidas. O encantamento suscitado é no sentido de enxergar a possibilidade de se apropriar e compartilhar de um entendimento crítico acerca dos problemas escolares e das políticas públicas em educação. A indignação, por sua vez, é com base na forma como as questões educacionais são entendidas por certas correntes dominantes, nas quais os indivíduos, na maioria das vezes professores e alunos, são culpabilizados pelos resultados insatisfatórios que acometem o ensino brasileiro.

Em 2012, realizamos um trabalho de iniciação científica intitulado Os conselhos de classe: entre a contradição e a superação, no qual houve um primeiro contato com a pesquisa e identificamos a possibilidade de poder refletir sobre as práticas escolares e as políticas públicas em educação. O trabalho foi de extrema importância para nossa formação intelectual e despertou o desejo de participar ativamente na escola, não apenas como pesquisador, mas como professor.

Em 2013, ocorreu o ingresso como professor de história na rede municipal de ensino, em uma escola de periferia da Zona Leste de São Paulo. Inseridos no contexto escolar, pudemos acurar nossas reflexões e vivenciar as contradições que permeiam uma escola de periferia. A tentativa de garantir uma educação de qualidade às crianças e jovens de baixa renda, em meio às dificuldades da prática e da carreira (como: a indisciplina, o fracasso escolar, os rituais burocráticos, a desvalorização e adoecimento docente, as políticas autoritárias e o descaso do poder público) fazem da educação um desafio idílico. Por outro lado, o compromisso com a escolarização desses jovens faz da tarefa docente um compromisso político e social, de importante contribuição para o desenvolvimento dos discentes como cidadãos de direito, como seres pensantes, questionadores e atuantes em sua realidade. Nada mais motivador para um professor do que acompanhar o aprendizado de um educando. A tarefa docente é desafiadora e recompensadora.

Em 2013, a escola, na qual atuamos desde então, começou um processo de implementação do Programa Mais Educação Federal (PME), política indutora do ensino em 
tempo integral em todo país. Participamos diretamente desse processo e pudemos partilhar das expectativas do grupo em relação à efetivação e desenvolvimento dessa empreitada. Ficou evidente um não completo entendimento, por parte do grupo de professores e gestores da unidade, sobre o que seria um projeto de educação integral por meio do PME. Havia um desconhecimento sobre o que era essa política, o que almejava e com quais intenções.

As expectativas não eram homogêneas em relação à implementação de um projeto de educação integral. Elas perpassavam por muitas justificativas, tais como: as projeções de melhora de "atitude" na sala de aula; a melhoria nos índices do IDEB; a tentativa de resgatar as crianças da rua; o emprenho em propiciar momentos de recreação e lazer; o intento de trazer uma formação mais completa em múltiplas áreas do conhecimento e a disposição em ter maior tempo para desenvolver o PPP da escola. Não havia também um consenso sobre a finalidade do aumento da jornada escolar. Sendo assim, desde então, pudemos observar de perto as dificuldades e desafios na adoção de um projeto de educação integral que ultrapassasse uma visão meramente instrumentalista e assistencialista e que estivesse a serviço da qualidade do ensino e da transformação social.

As atividades do PME se iniciaram apenas dois anos depois, em 2015, com descontinuidades e uma série de entraves burocráticos que impossibilitaram uma experiência sólida. A principal dificuldade prática era encontrar professores ou oficineiros que estivessem disponíveis para realizar atividades nos horários do programa. Aos professores da prefeitura de São Paulo que querem desenvolver projetos pelo PME é pago um valor de JEX (jornada especial de hora-aula excedente), porém a maioria com suas jornadas duplas não detêm de tempo livre ou não desejam ficar mais tempo na escola. No caso dos oficineiros, é pago uma quantia de R\$ 80 (oitenta) reais por mês mediante a assinatura de um termo de trabalho voluntário, o que faz com que o número de interessados seja quase nulo ou, em alguns casos, que o trabalho na escola seja interpretado como "bico", o que gera uma rotatividade imensa de envolvidos.

Nessas condições, um efetivo projeto de educação integral ainda não se consolidou na escola em questão e, para não cair na tentação de procurar culpados (sejam os professores, a gestão ou a comunidade "pouco engajada"), surgiu-nos a vontade de tomar o PME como objeto de estudo. Por se tratar de uma política indutora e de cunho nacional, sabemos que o PME pode ter encontrado muitos outros desfechos. A despeito das expectativas iniciais das quais também compartilhamos e diante dos entraves desse contexto específico, surgiram questionamentos para compreender melhor o PME como política pública nacional de educação integral e seu real 
compromisso com a educação popular, mediante os contextos histórico, social e econômico atuais.

É importante ressaltar que, no ano de 2016, o PME foi completamente reformulado, reestruturado e batizado de Programa Novo Mais Educação, o que nos trouxe novos desafios para tentar compreender os sentidos e propósitos que permearam essas mudanças.

Nosso interesse pelo tema de pesquisa surge a partir das questões elencadas acima, desencadeadas na escola, e dos questionamentos levantados pelo grupo de estudos em psicologia da educação, que participamos desde 2012 na FEUSP - sob a orientação da professora Sandra Sawaya. Surgiu-nos a possibilidade de refletir, entender e questionar os problemas escolares e as políticas públicas em educação por meio de um olhar compromissado com a melhoria da educação das classes populares. A escolha definitiva do tema de pesquisa surgiu em uma de nossas reuniões do grupo de estudos, o que veio a satisfazer o desejo de poder olhar mais de perto, com compromisso e cuidado, uma política pública de educação que dialogasse com nossa prática docente.

\subsection{Um primeiro olhar para a educação no Brasil}

O Brasil chega ao século XXI com resultados insatisfatórios nos processos de escolarização. Apesar dos progressos rumo à universalização do Ensino Fundamental, tornouse de domínio público a baixa qualidade do ensino. Consequentemente, surgem clamores, pelos diversos atores da sociedade, por melhorias da educação, o que também gera um campo de disputas a respeito do que se consistiria como uma educação de qualidade.

Até período recente, o número de crianças fora das escolas atingia percentuais inaceitáveis. Nos anos oitenta, a não frequência de discentes (entre 7 e 14 anos) nas escolas, aproximava-se dos 7,6 milhões, o que correspondia a 33\% das crianças e adolescentes em idade escolar. Em 1996, a não frequência nessa faixa etária era de 3,2 milhões, isto é, de 6,6 a 7,1\% das crianças entre 9 e 11 anos; 10,8 \% das crianças de 7 anos e 16,9\% dos adolescentes de 14 anos (FERRARO, 2004). Atualmente, segundo dados do MEC, 97,4\% das crianças e adolescentes entre 6 e 14 anos estão matriculadas no Ensino Fundamental. Entretanto, apenas $76 \%$ terminam o Ensino Fundamental com 16 anos ou menos.

A exclusão da escola, medida pela estatística de não frequência dos alunos em idade escolar regular, foi acompanhada da exclusão na escola que é caracterizada pelas sucessivas reprovações e repetências que levam a defasagens de idade e série, consequentemente seguidas 
de evasão. No ano de 1972, de cada mil crianças que se matricularam na primeira série, 526 prosseguiram na segunda série no ano seguinte e apenas 180 conseguiram terminar a oitava série (ROMANELLI, 1978). Em 1996, a defasagem idade/série representava 5,2\% do total de crianças de 8 anos e atingia 45,9\% aos 14 anos. (FERRARO, 2004).

Nos últimos anos, após a Lei de Diretrizes e Bases da Educação (n. 9.394/96), houve uma intensa mobilização contra os mecanismos de reprovação e repetência. A possibilidade de adoção de mecanismos como os ciclos, a progressão continuada, a aceleração de estudos, a recuperação paralela e a reclassificação foram adotadas em muitos sistemas de ensino, o que contribuiu para melhorar o fluxo idade/série. Segundo dados do INEP, em 2015, 3\% das crianças do $1^{\circ}$ ano e $23 \%$ dos adolescentes do $9^{\circ}$ ano encontravam-se em situação de defasagem com relação à idade/série. De cada 100 alunos de todo o Ensino Fundamental, 13 estavam com dois anos ou mais de atraso escolar. Apesar dos desafios remanescentes para a universalização do Ensino Fundamental e para a eliminação da defasagem de idade/série, uma grande parcela da população, que antes estava excluída da escola, agora passa anos dentro das instituições de ensino.

Pierre Bourdieu, ao analisar o contexto educacional francês aponta que, a partir da entrada massiva das classes populares nas escolas, a exclusão do sistema escolar por mecanismos de seleção, baseados no dom e no mérito, é substituída por outra dentro da própria escola, gerando os "excluídos do interior". O autor declara que a escola sempre exclui, "mas agora de maneira contínua [...] e mantém no seu seio aqueles que exclui” (BOURDIEU, 1998, p.224). Tratava-se de um ensino aberto a todos, mas reservado a uma parcela privilegiada da população.

O processo de eliminação foi diluído no tempo e a exclusão escancarada dá lugar a uma "eliminação branda", em que o período de escolarização é estendido, o que faz com que o indivíduo tenha tempo para dissimular para si mesmo a ilusão de uma escola democrática e para todos. A conclusão é que a escola "consegue a façanha de reunir as aparências da 'democratização' e a realidade da reprodução, que se realiza num grau superior de dissimulação, e por isso com um efeito maior de legitimação social” (BOURDIEU, 1998, p.223).

Maria Helena Patto, a partir da análise de Bourdieu, aponta que no Brasil, para além da exclusão brutal, não acesso e evasão, instauraram-se práticas de exclusão brandas, isto é, substitui-se a "eliminação brutal" pela "eliminação sutil" (PATTO, 2000), o que produz efeitos perversos, pois, com a "democratização da escola" a oportunidade estaria dada indiscriminadamente a todos. Sendo assim, o fracasso seria culpa unicamente do indivíduo que não aproveitou sua chance satisfatoriamente. Essa é uma lógica de democratização falsa que 
escamoteia as condições reais do ensino e da escola destinada às classes desfavorecidas: uma escola pobre para os pobres. A escola mantém em seu interior aqueles que antes eram expurgados e os responsabiliza pela precária formação que lhes é oferecida. Nas palavras de Patto,

\begin{abstract}
A política atual caracteriza-se por tentativas de internalização escolar dos expulsos, seja pela criação de uma rede de caminhos dentro da escola de primeiro grau - os quais, sob o pretexto de incluir, prolongam a ilusão da inclusão, pois, mesmo que os percorram, esses alunos não tiveram acesso a um ensino que se possa dizer de boa qualidade-, seja pelo afrouxamento dos critérios de avaliação da aprendizagem, com intenção clara, mas não confessada, de empurrar de qualquer jeito estudantes de baixa renda pelos graus escolares adentro, quando possível até o terceiro grau (PATTO, $2 \mathrm{OOO}$ pág. 193).
\end{abstract}

Houve então uma reedição dos sistemas de exclusão, agora com a maioria das crianças e jovens de baixa renda dentro dos sistemas de ensino. Surgiu assim uma nova modalidade de fracasso escolar, consequência de políticas públicas em educação com discursos pretensamente igualitários, mas que criam uma igualdade ilusória sobre a aparência da democracia, na tentativa de fazer desparecer as desigualdades e as contradições de uma sociedade dividida em classes. Aos extratos desfavorecidos são relegados anos de escolarização precária, levando-os a posições subalternas sob justificativas meritocráticas.

Para Marilena Chauí, a noção de democracia é definida por três grandes direitos: igualdade, liberdade e participação. A igualdade se caracteriza pelo tratamento igual e pela distribuição igualitária dos mesmos direitos; a liberdade se caracteriza pelo direito de qualquer um expor em público seus interesses e tê-los debatidos, devendo prevalecer a decisão da maioria; já a participação se caracteriza pelo direito à voz nas discussões e deliberações públicas. Portanto, só existe democracia, com a garantia de que os direitos sejam distribuídos de maneira igualitária, mediante a ampla participação de todos em sua construção e deliberação, visando o atendimento da maioria. A autora aponta que, em uma sociedade capitalista, a democracia gera conflitos de interesse: "expressão do fundamento mesmo da divisão social, contradição entre capital e trabalho, dominação de uma classe por outra" (CHAUÍ, 2012 pág. 153).

A expansão da escolarização, apesar de ter ido ao encontro das reinvindicações da sociedade e de movimentos populares, não se caracterizou como democrática. A escola que foi entregue à população não satisfez os anseios de uma educação cumpridora de seu papel, isto é, que ensine e que traga efetivas oportunidades. O que se vivenciou, na maioria das vezes, foram escolas sem infraestrutura básica, superlotadas, com professores mal pagos e desestimulados. Verificaram-se assim políticas públicas autoritárias que culpam seus atores centrais, professores 
e alunos, pelos seus resultados insatisfatórios. O direito à educação torna-se privilégio de determinados segmentos, é transformado em mercadoria e prestação de serviço, pois para obtêlo é preciso pagar.

A chamada "democratização do ensino" não trouxe um ensino de qualidade àqueles que adentravam a escola. Independentemente do que se entende por qualidade da educação, dentro dos mais distintos referenciais teóricos, o fato é que muitas crianças e adolescentes passam anos nos bancos escolares e são incapazes de interpretar um texto e realizar cálculos simples. Surge então na sociedade, nos trabalhos acadêmicos e nas políticas públicas, preocupações referentes não apenas à garantia do acesso e permanência das crianças e adolescentes na escola, mas um debate referente à qualidade da educação oferecida.

O prolongamento da jornada escolar, sob a perspectiva de grande parte dos debatedores, é uma das apostas para a melhoria da educação e para o combate ao fracasso escolar. Uma das metas dos PNE (2011-2020) é oferecer educação em tempo integral, em 50\% das escolas, de forma que ela atenda, até 2020, pelo menos 25\% dos alunos do ensino básico. Acredita-se que maior tempo em atividades educativas propicia melhores resultados de aprendizagem e, portanto, esta seria uma das chaves centrais para a consolidação de uma educação de qualidade.

\subsection{Educação integral, Educação em tempo integral e Educação integrada}

O aumento da jornada escolar não está necessariamente vinculado ao que se ocasionou chamar de educação integral. Esta última está relacionada a um projeto de formação com vistas ao alcance da integralidade do indivíduo dentro de determinada concepção história, social, política e filosófica. Não são propostas homogêneas dentro das variadas correntes e pensamentos educacionais da história da educação ${ }^{1}$ e de hoje. Nos documentos oficiais sobre o tema e na literatura especializada, a educação integral também é utilizada para designar a ampliação do tempo de escolarização, o que por si só não caracteriza um projeto de educação integral $^{2}$.

Na visão de Ligia Coelho (2009), a gênese da ideia de educação integral remonta aos gregos antigos. O fundamento de uma formação mais completa que comtemple o corpo e o

\footnotetext{
${ }^{1}$ Anarquistas, integralistas, liberais, propuseram um modelo de educação que denominaram de educação integral. Discutiremos os aspectos históricos no capítulo 1.

2 São encontradas diferentes terminologias acerca da ampliação da oferta de horas de atividades educativas: escola de tempo integral, escola de dia todo, escola de jornada completa, educação integral de tempo integral, educação integral em tempo integral, educação em período integral.
} 
espírito estava no ideário de Paidéa grega, uma visão que não hierarquizava saberes e experiências, mas os colocavam como complementares a partir de uma visão social de mundo. Assim, "conforme podemos constatar, há, na concepção grega de formação humana, uma espécie de igualdade entre as reflexões e as ações que constituem essa formação, sejam elas intelectuais, físicas, metafísicas, estéticas ou éticas" (COELHO, 2009, p.85). Para a autora, a ideia é resgatada na revolução francesa pelos jacobinos, que pretendiam o surgimento de um homem completo, formado em suas dimensões físicas, intelectuais e morais, por meio de uma educação pública ministrada pela escola. Cabe ressaltar o papel central da escola como local de disseminação da educação com o intuito de formação do homem segundo os moldes da liberdade e da igualdade.

Segundo Silvio Gallo (2002), o conceito de educação integral surgiu no século XIX, fruto da ideia de emancipação humana, que por meio do socialismo, em seus diversos matizes, propunha o fim da exploração e da dominação do homem pelo homem, características das sociedades capitalistas. O surgimento desta visão se encontra no movimento operário, que emergiu, com a Revolução Francesa e passou a reivindicar que o Estado fornecesse educação pública e gratuita, no intuito de garantir oportunidades maiores e melhores para o operariado e seus filhos. Assim, a visão de educação integral, em sua origem, estaria ligada à crítica a uma educação burguesa e, principalmente, à ideia central de uma educação inovadora e revolucionária.

A maioria dos autores consultados entende educação integral a partir do referencial teórico da Escola Nova e das ideias de Anísio Teixeira: Cavaliere (2002), Coelho (2009), Nunes (2009), e Moll (2013). Ana Maria Cavaliere, por exemplo, compreende o conceito como "reconstrução da experiência", com base nas conceituações de John Dewey, nas quais a escola deveria constituir-se em uma micro sociedade, com a finalidade de propiciar experiências reais de vida e não apenas preparatórias. Esse entendimento indica que "Essa noção da aprendizagem através do meio, o que significa através de vivências e não da transmissão direta e meramente formal de conhecimentos, é uma das características típicas das diversas concepções de educação integral" (CAVALIERE, 2002 p.260). A escola, portanto, teria a função de propiciar articulações entre a atividade intelectual com experiências da vida comunitária para o alcance de uma formação multidimensional.

Desta forma estaria a escola balizando a configuração intencional de seu ambiente em experiências individualmente e socialmente relevantes, e evitando pré-conceitos e cristalizações que lhe retirariam a capacidade de promover processos significativos de reconstrução da experiência. Uma das bases da concepção de educação integral é, justamente, esta predisposição de 
receber os educandos como indivíduos multidimensionais (CAVALIERE, 2002, p.262).

Para Lucia Maurício (2009), o educando deve ser entendido como um ser completo e não dividido entre corpo e intelecto. A educação integral deve propiciar uma formação de caráter múltiplo que envolva os aspectos cognitivo, social, afetivo, cultural, físico e estético. Nesse intuito, a integralidade deve ser atingida por meio do estudo de diversas linguagens em variadas circunstâncias e atividades.

Sob outra ótica, Vitor Paro $(2009 ; 2014)$ afirma que a educação integral é entendida como a apropriação da cultura ${ }^{3}$ historicamente produzida pelos seres humanos. É na escola que a cultura deve ser apropriada para uma formação integral do indivíduo como sujeito. A necessidade da educação se dá, pois "embora autor da história pela produção da cultura, o homem ao nascer encontra-se inteiramente desprovido de qualquer traço cultural" (PARO 2014, p.25). A educação, nessa concepção, visa à apropriação da cultura e não sua transmissão, uma vez que a transmissão é uma atividade unilateral, ou seja, um indivíduo transmite e o outro recebe por determinado tempo até findar a transmissão. Já a apropriação envolve algo duradouro que é construído conjuntamente.

A educação deve ser construtora de sujeitos, isto é, deve estar a serviço da atualização histórico-cultural dos indivíduos (PARO, 2014). O educando não é apenas um receptáculo de informações. Sendo assim, nas práticas educativas, deve haver apropriação, recriação e criação de cultura. Na escola, o aluno deve ser enxergado como ser histórico capaz de manifestar-se diante do real e transformar-se como sujeito. Para isso, a informação por si mesma não é suficiente, é necessária outra relação que considere o educando como ser social, político e histórico. Segundo o autor, "educação integral, em última instância, é um pleonasmo: ou a educação é integral ou, então, não é educação" (PARO, 2009, p.13)

Cezar Freitas e Maria Galter (2009) expõem três terminologias para o debate sobre a temática: educação em período integral, educação integral e educação integrada.

Para os autores, a educação integral seria uma formação relacionada às bases marxistas. Em uma perspectiva similar àquela evidenciada por Gallo (2002), a educação teria por finalidade trazer a consciência de classe e a elevação intelectual, moral e política, por meio da educação científica e também do ensino industrial e prático. Freitas e Galter (2009) apontam

\footnotetext{
${ }^{3} \mathrm{O}$ conceito de cultura para o autor envolve "conhecimentos, informações, valores, crenças, ciências, arte, tecnologia, direito, costumes, tudo enfim que o homem produz em sua transcendência da natureza." (PARO, 2014, p.23)
} 
que essa concepção pressupõe uma formação abrangente de todos os aspectos da vida humana, não se referindo especificamente à educação em período integral.

A educação integrada seria uma proposta mais preocupada em integrar ou adaptar os indivíduos das camadas desfavorecidas da sociedade de classes do que formá-los para a criticidade ou para a transformação social. A escola tomaria como sua responsabilidade funções como saúde, segurança, moradia e lazer, consistindo-se em instituição mais assistencial do que propriamente educativa.

A educação em período integral estaria relacionada ao tempo diário das aulas e não se trata- de uma novidade histórica.

Quando a escola se constituía como privilégio de uma pequena parcela da população e era voltada para a formação dos quadros dirigentes da sociedade, a tarefa educativa era realizada em período integral. (FREITAS E GALTER, 2007, 124).

Em muitos trabalhos, na legislação e em documentos oficiais, a educação integral é confundida com o aumento do tempo de escolarização. Podemos afirmar que educação integral aparece como sinônimo de educação em tempo integral.

Cavaliere afirma que a expansão do tempo diário na escola pode ser justificada de diversas formas:

\begin{abstract}
a) ampliação do tempo como forma de se alcançar melhores resultados da ação escolar sobre os indivíduos, devido à maior exposição desses a práticas e rotinas escolares b) ampliação do tempo como adequação da escola às novas condições de vida urbana, das famílias e particularmente da mulher c) ampliação do tempo como parte integrante da mudança na própria concepção de educação escolar, isto é, no papel na vida e na formação dos indivíduos. (CAVALIERE, 2007 p.1016).
\end{abstract}

Para a autora, a última concepção é a que garantiria uma educação em vistas à formação integral do homem. Em sua concepção, uma maior quantidade do tempo escolar não garante, por si só, melhorias na educação, porém, sua inserção pode propiciar práticas escolares melhores. Partindo da filosofia pragmatista de Dewey, a autora ainda afirma que: "Caso se considere que preparar indivíduos para a vida democrática é função da escola, o tempo integral pode ser um grande aliado" (CAVALIERE, 2007, p.1022).

Paro também afirma que o aumento da jornada não garante uma educação de qualidade. Segundo ele, "é preciso que este ponto fique muito claro, para separarmos de vez uma tendência que entende que a extensão do tempo de escolaridade seja apenas isso: fazer em mais tempo 
aquilo que já se faz hoje" (PARO, 2009, p.13). Para o autor, é fundamental a articulação entre educação integral e educação em tempo integral para o combate a uma formação meramente tecnicista e informativa que produz a alienação.

A educação em tempo integral também é pauta de organismos financeiros internacionais ${ }^{4}$ e do empresariado, os chamados reformadores neoliberais ${ }^{5}$ da educação. Orientações e recomendações de instituições financeiras passaram a fazer parte das políticas de educação dos países em desenvolvimento. Tal inclusão deu-se a partir da Conferência Mundial sobre a Educação para Todos, realizada em 1990, na Tailândia. Esse evento destacou, como paradigma para a educação no século XXI, o debate sobre o "aprender a aprender", que foi amplamente divulgado pelo Relatório da Unesco “Educação: um Tesouro a descobrir” de 1999.

A partir do relatório da UNESCO desenvolve-se uma concepção de educação em que a escola não é a única responsável pela formação das gerações futuras. Passa a ser, então, responsabilidade de toda a sociedade promover oportunidades de aprendizagem em torno de uma "sociedade educativa" para uma "educação ao longo da vida". Na década atual, o relatório da OCDE, "Competências para o Progresso Social” (2015), advoga a importância da adaptação dos currículos escolares para abordar as competências socioemocionais na escola. Nessa percepção, atividades extracurriculares complementares (esportes, atividades artísticas e associações de governança estudantil) ajudam na aquisição de competências, como: responsabilidade, perseverança, capacidade de trabalhar em equipe e autoconfiança. Para a OCDE, estas são experiências a serem desenvolvidas fora da sala de aula, com ajuda de adultos "facilitadores".

Para o Banco Mundial (BM), em relatório sobre a educação brasileira em 2010, Achieving World class education in Brazil, the next agenda, as competências para o século XXI incluem as seguintes características: pensar analiticamente, gerenciar grandes quantidades de informações e dados, fazer perguntas críticas e aprender novas competências, ser comunicativo, adaptar-se a carreiras e trabalhos em constante mudança durante a vida adulta, isto é, ser um trabalhador versátil e polivalente (dominar línguas estrangeiras, saber trabalhar em equipe e desenvolver tarefas colaborativas). No documento, para o encalce das habilidades supracitadas,

\footnotetext{
${ }^{4}$ São muitos os organismos internacionais envolvidos com as questões de educação, sendo os principais deles: A Organização das Ações Unidas para a Educação (UNESCO), o Banco Mundial (BM), o Fundo das Nações Unidas para a Infância (UNICEF) e o Programa das Nações Unidas para o Desenvolvimento (PNUD), A organização para cooperação e desenvolvimento econômico (OCDE).

5 Terminologia utilizada por Freitas $(2012,2014)$ e Ravitch (2001).
} 
são necessárias ações que protejam o desenvolvimento básico das crianças em situação de vulnerabilidade social. (BANCO MUNDIAL, 2010). 


\section{O MAIS EDUCAÇÃO COMO PROBLEMA DE PESQUISA}

O PME foi instituído pela portaria Interministerial $n^{\circ} 17 / 2007$ e regulamentado pelo decreto 7.083/2010. É coordenado pela Secretária de Educação Básica (SEB/MEC), em parceria com as Secretárias Estaduais e Municipais de Educação. Ele integra as ações do Plano de Desenvolvimento da Educação (PDE) no âmbito do Plano de Metas Compromisso Todos pela Educação (Decreto n ${ }^{\circ}$ 6.094, de 24 de abril de 2007).

O projeto de educação compreendido pelo PME envolve a reformulação do currículo, dos tempos e espaços escolares e estabelece a participação da comunidade como agente ativo no processo educativo. A gestão do PME partiu de ações integradas entre todos os atores da sociedade e ações intersetoriais entre a União, Estados e municípios, além de ações interministeriais. Sua portaria de criação traz os Ministérios integrantes do Programa: Ministério da Educação (MEC); Ministério do Desenvolvimento Social e Combate à Fome (MDS); Ministério da Cultura (MinC); e Ministério do Esporte (ME), sendo que ações de outros Ministérios ou Secretarias Federais podem integrar o Programa.

Em outubro de 2015, passados sete anos de sua implementação inicial, a Fundação Itaú Social, em parceria com o Banco Mundial, divulgou o estudo "Relatório de avaliação econômica e Estudos Qualitativos - O programa Mais Educação MEC”, chegando à conclusão que o Programa não causou diminuição nas taxas de evasão escolar, não alterou o desempenho em língua portuguesa e gerou impactos negativos no desempenho de matemática dos estudantes participantes.

No mesmo dia da divulgação da publicação da Fundação Itaú, o ex-ministro da educação Aluízio Mercadante, em nota, comprometeu-se em ajustar o Programa Mais Educação. As modificações prometidas se concretizaram por meio da resolução $\mathrm{n}^{\circ} 2$ do FNDE, de 14 de abril de 2016, que estabeleceu: a) atender prioritariamente os alunos com problemas de alfabetização; b) atender prioritariamente estudantes com baixo rendimento na prova Brasil; c) atender posteriormente as escolas que fizeram sua inscrição em 2014; d) aumento da carga do macrocampo acompanhamento pedagógico; e) aumento da ajuda de custo dos monitores do campo acompanhamento pedagógico; f) aumento da ajuda de custo dos monitores das áreas rurais (BRASIL, 2016).

Em 2016, com o impeachment da presidente eleita e a troca de ministros nos quadros da administração federal, o PME é completamente reformulado e ganha o nome de Programa Novo Mais Educação (PNME). Aumentou-se a carga horária de português e matemática no 
contra turno e diminuiu-se a parte diversificada do currículo. O objetivo central e explícito nos documentos para essas mudanças é a melhoria da qualidade da aprendizagem dos alunos das redes públicas nessas disciplinas (BRASIL, 2016). Essas alterações, feitas sem nenhum diálogo com outros setores da sociedade e principalmente com os atores diretamente envolvidos com a execução do programa, deixaram evidente como os empresários da educação têm influência decisória na construção de entendimentos e consensos acerca da qualidade da educação e em decisões diretas sobre os rumos tomados pelas políticas públicas em educação.

Perante os baixos resultados do Brasil em testes internacionais como PISA (Programme for International Student Assessment), alardeados pela imprensa, a cada ano, os reformadores neoliberais aparecem no cenário educacional com um receituário de soluções baseadas na administração privada em que gestão, management, eficácia, eficiência e competitividade são palavras de ordem que promoveriam ações de melhorias instantâneas nos índices aferidos nas avaliações externas e, consequentemente, garantiriam uma educação de qualidade. Esse léxico adotado do mundo empresarial adentra a escola como neutro e técnico, contudo, são profundamente culturais e políticos. Como aponta Christian Laval, esses discursos permitem submeter a escola às lógicas sociais e econômicas que lhe eram estranhas, permitindo assim, a interiorização de novos objetivos alinhados às novas configurações do capitalismo. É o que o autor nomeia como redefiniçao da instituição escolar como "empresa educativa". (LAVAL, 2004). A visão empresarial vem norteando as políticas públicas de educação em todo mundo e no Brasil.

Na educação nacional, houve a intensificação da ação direta do empresariado na política educacional brasileira. Seu principal expoente foi o Movimento Todos pela Educação (TPE), iniciativa do empresariado, principal relator do Plano de Metas Compromisso Todos Pela Educação e com forte influência na elaboração do PDE (Plano Nacional de Desenvolvimento da Educação), criados em 24 de abril de 2007 pelo Ministério da Educação. É importante ressaltar que o PDE assumiu todas as metas do Movimento Todos Pela Educação, certificando a forte penetração do consenso construído pelos empresários na política pública educacional no Brasil. O PME surgiu como uma das metas PDE, com o objetivo de consolidar-se em uma política indutora de educação em tempo integral em todo o país.

Nas últimas décadas, assistimos ao ajuste dos sistemas educacionais às demandas da nova ordem do capital, pautados na privatização, na desregulamentação, na descentralização, na competitividade e no individualismo. A educação perde seu caráter de direito e torna-se uma prestação de serviços avaliada pelos resultados aferidos em testes de qualidade em avaliações externas. Segundo José Carlos Libâneo, a ação dos organismos internacionais, nos países 
emergentes ou em desenvolvimento, foi marcada por um fenômeno denominado internacionalização da educação, que tem por objetivo:

[...] a modelação dos sistemas e instituições educacionais conforme expectativas supranacionais definidas pelos organismos internacionais ligados às grandes potências econômicas mundiais, com base em uma agenda globalmente estruturada para a educação, as quais se reproduzem em documentos de políticas educacionais nacionais como diretrizes, programas, projetos de lei (LIBÂNEO,2016, p.43).

Como nos demonstram autores como Gentili (2005), Laval (2004) e Libâneo (2015). Essas agências financeiras compreendem a educação como ferramenta de combate à pobreza e desenvolvimento econômico a partir da inserção das camadas populares na economia de mercado. A partir de um discurso pretensamente humanístico e democrático, por meio de uma perspectiva gerencial e instrumental, advogam que o tempo escolar seja dispendido em ações que garantam melhor desempenho na obtenção de competências socioemocionais para a empregabilidade e um ensino voltado para os testes aferidos nos índices das avaliações externas.

Perante essas premissas, este trabalho tem como objetivo refletir acerca de: a) Qual a proposta de educação integral contida nos documentos do PME; b) Como dialoga ou resiste ao projeto dos reformadores neoliberais incorporado cada vez mais nas políticas públicas em educação. Para respondermos a essas questões centrais, recorremos às publicações de documentos oficias: os textos da lei, os cadernos pedagógicos, as publicações do MEC e outros documentos de institutos privados - todos disponibilizados na página do PME e no site MEC, além de recorrermos também a um levantamento bibliográfico pertinente às questões elencadas.

A hipótese deste trabalho compreende o PME como uma política pública contraditória, fruto do momento histórico e político que se desencadeou com os governos petistas (20022016). O período foi marcado por uma tentativa de conciliação entre os interesses das classes trabalhadoras, as aspirações da burguesia nacional e do grande capital, estas últimas colocadas de maneira explicita na "carta ao povo brasileiro" de 2002 que redirecionou as ações do Partido dos Trabalhadores (PT) para a lógica do capital internacional. É o que André Singer (2010) denominou reforma gradual e pacto conservador, onde os interesses capitalistas do mercado e do empresariado não teriam sido confrontados, muito pelo contrário, foram inseridos nas políticas de governo, ao mesmo tempo em que, ações destinadas aos mais pobres se tornaram marcos do período. Portanto, não houve rupturas e sim conciliação e apaziguamento entre interesses distintos e até opostos. Em nossa visão, como pretendemos demostrar através desse trabalho, as políticas em educação e especificamente o PME, seguiu essa mesma lógica. 
No Programa Mais Educação, havia uma real proposta de educação integral como formação de um ser em sua integralidade em seus diversos aspectos como humano, uma das poucas experiências na história da nossa educação que propunha outra lógica para além do ensino instrumental para as crianças e jovens das classes desfavorecidas em nível nacional. Ao mesmo tempo, houve uma tentativa de conciliação com os interesses e consensos disseminados pelos reformadores neoliberais da educação que não só recomendaram suas "boas práticas" rumo a "eficácia", como participaram da formulação do projeto como política pública. Com a extinção do PME, e o surgimento do Programa Novo Mais Educação, há um nítido alinhamento em direção as concepções e recomendações dos reformadores neoliberais da educação.

\subsection{Metodologia de pesquisa}

Para refletir a respeito das questões elencadas acima, recorremos às publicações de documentos oficias: os textos da lei e os documentos norteadores do PME, encontrados no endereço eletrônico do MEC, conforme anteriormente explicitado. Também foram objeto de estudo publicações do Centro de Estudos e Pesquisas em Educação, Cultura e Ação Comunitária (CENPEC), da associação Escola Aprendiz e da UNESCO, pois além de estarem disponíveis na página oficial do programa ${ }^{6}$ trazem conceituações que estão capilarmente presentes na formulação do PME.

Foram estudados os três cadernos da Série Mais Educação, que têm como intuito nortear a "conceituação, a operacionalização e a implementação" do PME. São eles: a) Gestão Intersetorial no Território; Muitos Lugares para Aprender b) Educação Integral - Texto Referência Para o Debate Nacional c) Rede de Saberes Mais Educação - Pressupostos para Projetos Pedagógicos de Educação Integral. Além disso, foram estudadas também outras publicações oficias do MEC, como: Passo a passo Mais Educação e Caminhos para elaborar uma proposta de Educação Integral em Jornada Ampliada - CECIP.

As legislações consultadas em nossas análises foram as que instituíram o programa Decreto $N^{o}$ 7083/10: Portaria Normativa Interministerial 17/07 e os manuais do Fundo Nacional de Desenvolvimento da Educação (FNDE), que orientam a adesão do PME nas unidades escolares em âmbito estadual e municipal. Estes documentos foram elaborados anualmente desde 2008 a 2014: Manual de Educação Integral para obtenção de Apoio Financeiro por meio do Programa Dinheiro Direto na Escola-PDDE, anos 2008, 2009, 2010;

\footnotetext{
${ }^{6}$ http://portal.mec.gov.br/programa-mais-educacao. Consultado em 05/01/2019.
} 
Manual de Educação Integral em jornada ampliada para obtenção de Apoio Financeiro por meio do Programa Dinheiro Direto na Escola-PDDE, ano 2011 e Manual operacional de Educação Integral, anos 2012, 2013 e 2014.

Outras publicações estudadas foram: Bairro Escola - Passo a passo, da Associação Escola Aprendiz em parceira com a Unesco; Cadernos CENPEC - Educação Integral; Boas práticas de municípios que garantem o direito de aprender ${ }^{7}$, caderno da UNESCO em parceria com o MEC, e, por fim, o texto da lei referente ao PNME: Portaria MEC $N^{o} 1.144 / 16$ e resolução FNDE $n^{o}$ 5/2016. Também foi analisado o documento Perguntas frequentes - Novo Mais Educação.

Para nossa análise, o texto da lei e as publicações oficiais e não oficiais nos permitiram uma tentativa de apreensão dos variados discursos explícitos e implícitos, que circunscrevem a proposição de determinado projeto no espaço escolar como política pública. Na visão de Otaíza Romanelli, “a organização da educação em determinada sociedade é, antes de tudo, um problema de ordem política. Essa afirmação decorre do fato que a organização se faz através da legislação [...] a legislação é sempre o resultado da proposição dos interesses das classes representadas no poder" (ROMANELLI, 1978, p. 188). Segundo a autora, a criação de uma lei e seus desdobramentos está relacionada seja aos interesses e demandas dos que legislam, seja às pressões sociais feitas pelos que não possuem poder de legislar. Isso faz com que a lei expresse além de seu texto, isto é, que diga mais seus reais propósitos nas entrelinhas do que em seu texto propriamente escrito.

Demerval Saviani (1985) aponta que, para acessar a real compreensão da legislação, não basta se ater à letra da lei, mas, sim, ao que está para além do que está escrito. Para ele, é preciso conhecer o contexto em que o texto foi produzido e sobre quais circunstâncias; em suma, é preciso enxergar as linhas e as entrelinhas. $\mathrm{O}$ autor elenca três etapas necessárias para a análise do texto da lei, a saber: 1 . Ter contato com a lei, para captar a estrutura do texto; 2 . Examinar as razões manifestas, isto é, o que diz propriamente o texto da lei; 3. Buscar as razões reais da formulação da lei, o que implica, a) fazer um exame de contexto histórico e b) examinar a gênese da lei, reconstituindo seu processo de elaboração, os atores e seus papeis nesse processo.

Propomos, então, um estudo descritivo-analítico a partir de uma investigação dos textos que pautam a implementação da educação do PME como política pública, além de bibliografia acadêmica que tomou a educação integral/em tempo integral como objeto de estudo: Bomeny

\footnotetext{
7 Toda legislação e publicações consultadas estão disponíveis na página do MEC na internet: http://portal.mec.gov.br.
} 
(2009); Cavalari (1999); Cavaliere (2002, 2003, 2007, 2010, 2014); Gallo (2001); Coelho (2005, 2009); Freiras e Galter (2007, 2012, 2014); Maurício (2002, 2009); Moll (2009, 2012), Nunes (2009), Paro (1988, 2009, 2014); Silva e Silva (2012, 2014).

Também foram tomados para análise documentos produzidos, principalmente, pelo Banco Mundial, OCDE e UNESCO, devido à capilaridade de suas propostas em educação nos países em desenvolvimento:

Relatório sobre o desenvolvimento mundial (BANCO MUNDIAL, 1990); Prioridades y estratégias para la educación. Estudio sectorial del Banco Mundial (BANCO MUNDIAL 1995); Relatório sobre o desenvolvimento Mundial (BANCO MUNDIAL, 2000); Achieving World class education in Brazil, the next agenda (BANCO MUNDIAL, 2010); Aprendizagem para todos (BANCO MUNDIAL, 2011); Relatório anual- Um mundo sem pobreza (BANCO MUNDIAL, 2013); Competências para o progresso social: o poder das competências socioemocionais (OCDE, 2015); Declaração Mundial sobre Educação para todos (UNESCO, 1990); Educação um Tesouro a descobrir (UNESCO, 1999); Tendências para a Educação Integral (UNICEF, 2011).

A fim de sustentar nossas reflexões, apoiamo-nos em autores críticos às propostas neoliberais para a educação, advindas, principalmente, dos organismos financeiros internacionais e do empresariado- Altmann (2002); Coraggio (1996); Duarte (2000); Fonseca (2001); Frigotto (2001, 2003); Frigotto e Ciavatta (2005); Freitas (2014); Gentili (2001, 2002, 2005); Haddad (2008); Laval (2004); Libâneo (2012, 2014, 2015, 2017); Kruppa (2001); Sawaya (2012); Torres (1996). 


\section{A EDUCAÇÃO INTEGRAL NO SÉCULO XX: UM PASSEIO PELA HISTÓRIA}

A ideia de educação integral nas escolas brasileiras não é nova. Embora o debate sobre o tema tenha ganhado força na última década e o número de escolas em tempo integral tenha aumentado exponencialmente com o PME, outas experiências ocorreram na história da educação no Brasil. O conceito de educação integral foi/é entendido de maneiras distintas em diversas épocas e por diversas correntes do pensamento educacional - dos socialistas anticlericais aos reformistas católicos, como aponta Gallo (2002), e das correntes autoritárias e elitistas para as correntes liberais, conforme destaca Cavaliere (2010). Neste primeiro momento, buscamos as primeiras definições sobre a educação integral nos debates em educação no Brasil, o que nos remeteu às décadas de 20 e 30, marcadas por um caldo de ideias que viriam a definir os primeiros entendimentos acerca da escolarização das camadas populares. Nesse intuito, nos apoiamos em autores como: Boto (1994/1995); Carvalho (1989, 1998, 1999, 2000, 2003); Cavaliere (2003, 2010); Romanelli (1978) e Saviani (2006).

Com o advento da república, no fim do século XIX, começa uma nova fase da vida política nacional. Há uma disseminação profunda da concepção liberal nos meios intelectuais brasileiros que se constituíram em verdadeiros arautos de um novo modelo de sociedade, que surgia baseada no progresso e na modernização. Todavia, embora os princípios que legitimaram a república fossem a democracia e o liberalismo, o caráter elitista e autoritário da sociedade, característica do Império, permanecia intacto.

A república velha (1889 - 1930) ficou marcada pela alternância no poder entre as elites paulistas e mineiras. Havia mais uma tentativa de imitação do modelo liberal norte-americano do que qualquer intenção de execução real do liberalismo na gestão pública. Por meio de acordos entre as elites e o domínio dos coronéis, práticas de manipulação do voto alijaram a população de qualquer participação política. Não houve mudanças profundas na estrutura social, porém, o novo cenário que surgiu, criou condições para mudanças significativas no quadro político, econômico e social que desencadeariam na revolução de 30.

Parte da elite, insatisfeita com sua exclusão dos processos de decisão, partia dos ideais liberais e apostava na inserção do voto para alcançar a democracia. A intenção era republicanizar a república. Neste contexto, a educação passa a ser debatida por uma série de movimentos como fator fundamental de consolidação da república, seja para enfraquecer o voto de cabresto e a corrupção eleitoral, seja para implantar um modelo de sociedade aliada ao capitalismo industrial, ou até para instaurar a constituição real da democracia. Nesse contexto, 
a educação foi alvo de disputas entre atores do cenário da época, movimento que Nagle (1976) descreveu como entusiasmo pela educação (PATTO,2010).

A partir da década de 20 do século passado, a educação no Brasil passa a ser discutida como um problema da nação. O índice de analfabetismo do período atingia, como mostra Romanelli (1978), quase $70 \%$ da população brasileira. Na visão da autora, até a época do Império, a educação tinha como função social fornecer elementos do quadro político e administrativo da administração pública e formar os líderes e intelectuais do regime, o que fez com que a oferta de educação fosse quase inexistente e correspondesse às exigências daquela sociedade. Com o advento da República, ocorrem mudanças de um modelo exclusivamente agrário exportador para outro parcialmente urbano e industrializado, que passou a fazer solicitações para que a escola atendesse às necessidades de recursos humanos para os setores de produção recém-surgidos. Em contrapartida, a demanda social por educação aumentou e fez com que extratos médios e populares demandassem que a escolarização se expandisse. Nesse sentido,

Se antes na estrutura oligárquica, as necessidades de instrução não eram sentidas, nem pela população, nem pelos poderes constituídos (pelo menos em termos de propósitos reais), a nova situação implementada na década de 30 veio modificar profundamente o quadro das aspirações sociais, em matéria de educação, e, em função disso a ação do próprio Estado (ROMANELLI, 1978, p.59).

As décadas de 20 e 30, marcadas pela efervescência do campo educacional, presenciaram uma série de embates e conflitos que envolveram diversas correntes de pensamentos ideológicos distintos. O tema da educação integral aparece nesse cenário por meio de concepções que foram propostas por correntes socialistas, conservadoras e liberais, sendo que, esta última, emergiu com o advento das concepções pedagógicas da escola nova - a vertente hegemônica até os dias atuais.

Neste capítulo, apresentaremos as correntes de educação integral que marcaram o pensamento educacional do século $\mathrm{XX}$ e seus desdobramentos em experiências posteriores. Coelho (2004), a partir de uma análise político-filosófica, apresenta três correntes do pensamento educacional que, em nossa visão, sintetizam as principais concepções do período: a Conservadora, a Libertária, e a Liberal. Esses três movimentos serão analisados no decorrer deste capítulo. Nosso intuito é buscar os aspectos políticos, sociais e educacionais dessas propostas a partir de um olhar sobre a história da educação. 
É importante observar que, para os intelectuais da década de 20 e 30, a educação integral não tinha o sentido de escola de dia inteiro, portanto, não estava ligada à ideia de escola de tempo integral. O sentido de educação integral era pensado como meio de modificar o papel da ação educativa, com vistas ao aparecimento de uma escola que propiciasse uma formação de acordo com o modelo que atendesse a concepções políticas, sociais e filosóficas de cada grupo. Seria, pois, uma educação que satisfizesse as demandas de uma determinada sociedade ou que viesse a contribuir para o alcance de outra. Em suma, era um sentido oposto ao de mera instrução pelas letras e números.

Na segunda parte do capítulo, nos propusemos a resgatar a história das experiências precursoras dos projetos de educação integral em tempo integral no Brasil: são, sem dúvida, a de Anísio Teixeira na Bahia, nos anos 40, com o Centro Educacional Carneiro Ribeiro (CECR) ou Escolas Parque; e a escola arquitetada por Darcy Ribeiro, quando vice-governador de Leonel Brizola no Estado do Rio de Janeiro, nos anos 80, com seus CIEPS (Centros Integrados de educação pública). Essas experiências foram tentativas importantes de consolidar um projeto de educação integral em solo nacional, e sem dúvida alguma, foram as prenunciadoras do PME.

\subsection{A educação integral libertária}

A educação integral libertária teve nas ideias socialistas, difundidas por Marx, seus pilares centrais. A educação tinha um papel político e social claro, estava a favor da luta das classes dominadas contra as classes dominantes. A reformulação da escola estava associada ao rompimento da divisão trabalho manual/intelectual e havia uma ligação clara entre educação e trabalho, da mesma forma que entre educação e tomada de consciência de classe. Coube a um pedagogo francês e militante do movimento operário - Paul Robin (1837-1912) - sistematizar e estruturar uma prática pedagógica anarquista.

A educação integral foi uma das propostas da Associação Internacional dos trabalhadores, em 1868. A importância do tema teria sido levada à discussão por Robin, como um dos tópicos da luta dos trabalhadores. Ao assumir a direção do Orfanato Prévost, em Cempius, na França, entre 1880 e 1894, Robin teria desenvolvido uma experiência de educação integral e pôde testar seus conceitos e colocá-los em prática (GALLO, 2002).

O primeiro dos conceitos apregoado por Robin é que a educação integral é um processo de formação humana, sem término, em que o homem está em constante construção e reconstrução. Assim, a educação integral ocorre a partir de uma formação para a integralidade 
do ser, que visa à construção de um homem que se faz plenamente humano por meio da articulação e do relacionamento intrínseco entre indivíduo e sociedade. Segundo Paul Robin,

Todo homem deve ser considerado sob dois pontos de vista: como ser isolado, independente, completo por si só, e como membro da coletividade. Nenhuma delas pode ser sacrificada pela outra. Como ser distinto e completo, ele tem direito ao desenvolvimento total das suas faculdades; como membro da coletividade, ele deve contribuir com sua parte de trabalho íntegro e necessário (ROBIN, apud GALLO, 2002, p.33).

Conforme Gallo (2002), outro conceito, nesta mesma chave teórica, é a importância dada à educação profissional. Por meio da educação, deveria ocorrer uma integração entre trabalho manual e trabalho intelectual, de acordo com uma verdadeira superação dessa dicotomia. Esse processo deveria contribuir para a superação da alienação, a partir de um pleno conhecimento de si mesmo e de seu meio, o que traria ao trabalhador a consciência da importância de seu papel na sociedade. Essa concepção articula-se mediante três instâncias: a educação intelectual, a educação física - que se desdobra em esportiva, manual e profissional - e a educação moral, compreendida como uma vivência escolar por meio da liberdade e da solidariedade a fim de organizar uma nova prática social. Portanto, para os anarquistas, o conhecimento é uma forma de poder, o que faz com que, com uma educação justa aos trabalhadores, o conhecimento deixe de ser um fator de dominação para ser uma ferramenta em favor do fim da exploração e da sociedade de classe.

Nessa perspectiva, a educação integral deve contribuir para a superação das contradições da sociedade capitalista. O indivíduo deve ter conhecimento de si próprio, de seu meio e dos mecanismos de dominação e alienação. Assim, não basta saber pelo saber, é fundamental um saber compreendido em todas as suas dimensões. Tal fato requer uma educação que leve em consideração o ser humano em suas múltiplas relações e dimensões a partir de sua singularidade e universalidade. Dessa forma, a educação integral não opera apenas na formação do indivíduo, mas de toda a sociedade.

Nesse contexto do cenário internacional, essa concepção de educação integral, chega ao Brasil, trazida pelos imigrantes europeus, no final do século XIX. Segundo Moraes et all (2012), esses trabalhadores, vindos da Europa para trabalhar nas lavouras de café, trouxeram os preceitos da pedagogia libertária. Em seus países de origem, as ideias socialistas e anarquistas haviam penetrado os movimentos sociais que buscavam transformações nas condições de trabalho do operariado. Em decorrência desse cenário, educadores anarquistas estrangeiros influenciaram o pensamento brasileiro, principalmente Paul Robin, com seu conceito de 
educação integral, e Francisco Ferrer, com seu ensino racionalista da experiência da Escola Moderna de Barcelona. A educação libertária no Brasil foi empreendimento de segmentos dos trabalhadores no intuito de alcançar mudanças na sociedade. Essas concepções deram origem a experiências de pedagogias libertárias em várias capitais do país, como o caso da escola Moderna ${ }^{\circ} 1$ e a Escola Nova de João Penteado (1876-1966), ambas em São Paulo.

O fuzilamento de Francisco Ferrer $^{8}$, em 1909, causou comoção e iniciativa que resultou na criação da Comissão Pró Escola Moderna, o que germinou debates criando-se condições para o ensino libertário em São Paulo. João Penteado, um dos principais propositores da pedagogia libertária no Brasil, juntamente com o movimento anarquista paulista, funda a escola Moderna nº 1 , em 1912 - no bairro operário do Belenzinho - como clara homenagem à Escola moderna de Barcelona. A proposta tinha como pressupostos a educação integral de Robin e Ferrer. Ambos propunham o rompimento com o Estado e com a Igreja, assim como com a concepção de formação parcial, voltada unicamente para o trabalho. A educação, na concepção anarquista, tinha como missão o desenvolvimento por completo, não apenas nos espaços formais, mas também por meio de intervenções em bibliotecas populares, centros de estudos e grupos de teatro. A concepção pedagógica também estava pautada no racionalismo humanitário que consistia na extinção de preconceitos por meio do conhecimento com intuito de combater as desigualdades e exclusões (MORAES et al, 2012).

Segundo as autoras (MORAES et al, 2012), no programa da escola constavam as disciplinas de português, aritmética, geografia, história, desenho, caligrafia e préstimos, além de oferta noturna com aulas de línguas estrangeiras voltadas para o adulto trabalhador. Havia aulas aos finais de semana e encontros com os familiares dos estudantes para estudo e esclarecimento da pedagogia libertária. O encerramento das atividades da Escola Moderna ocorreu no ano de 1919, data de intensa repressão do movimento operário. Após o fechamento da escola Moderna $\mathrm{N}^{\circ} 1$, João Penteado vai dirigir outra escola, a Escola Nova, localizada também no bairro do Belenzinho, à Rua Saldanha Marinho.

Em 1924, a escola passa a se chamar Academia de comércio Saldanha Marinho e em 1928, ganha reconhecimento dos seus diplomas expedidos: título de contador e os de graduado em ciências econômico-comerciais. Em 1931, a reforma geral do ensino comercial de Francisco Campos traz controle e centralização em demasia, tornando "rígida e inelástica a organização do ensino" (MORAES et al, 2012, p.1009). Todavia, os jornais da Academia de comércio

\footnotetext{
${ }^{8}$ Para informações detalhadas do pedagogo ver Francisco Ferrer, o mártir da escola moderna. Gallo, 2013.
} 
Saldanha Marinho sugerem a continuação dos princípios anarquistas de educação integral. João Peteado continuou como diretor da escola até seu falecimento, em 1966.

As ideias pedagógicas de educação integral libertárias foram reprimidas no início do século XX no Brasil e não conseguiram fazer frente ao referencial teórico liberal que marcou profundamente as concepções de educação integral. A seguir, descreveremos um pouco da proposta de educação integral conservadora que teve como seu principal difusor o Movimento Integralista Brasileiro.

\subsection{A educação integral conservadora- A década de 30 e a Ação Integralista Brasileira.}

O conceito concepção de educação integral conservadora foi uma proposta de um grupo que teve ampla participação no cenário das discussões políticas na década de 30. A AIB (ação integralista brasileira) foi organizada em 1932, e tornou-se partido político em 1935. Representante do conservadorismo elitista alinhado aos movimentos de ultradireita, como fascismo e nazismo, tinha como seu principal membro Plínio Salgado. Ancorados no lema Deus, pátria e família, obtiveram apoio das oligarquias tradicionais, da alta hierarquia militar e de setores conservadores da igreja.

Em 1937, com o Estado Novo, Getúlio Vargas dissolveu todos os partidos políticos, o que fez com que o partido integralista brasileiro assumisse o nome de Associação Brasileira de Cultura (ABC). Em 1938, em discordância com a dissolução dos partidos políticos, o movimento integralista organizou um levante armado, e numa tentativa frustrada, tentou destituir Getúlio Vargas do poder. A Intentona Integralista fracassou e seu líder Plínio Salgado foi exilado em Portugal. O objetivo da associação, segundo seu líder, era:

\footnotetext{
A AIB objectiva a reforma do Estado [...] de sorte que o povo brasileiro, livremente, $[\ldots]$ possa assegurar, de maneira definitiva, evitando luta entre províncias, entre classes, entre raças, entre grupos de qualquer natureza e, principalmente, evitando rebeliões armadas: - o culto de Deus, da Pátria e da Família (SALGADO, apud, COELHO, 2005b n.p).
}

O movimento integralista brasileiro propôs um modelo de educação integral que seria peça-chave na instituição de um homem completo, segundo os valores da pátria e da moral cristã. Tratava-se de uma "educação integral para um homem integral". Nas palavras de Cavalari, a AIB 
[...] se propõe a educar o homem todo. E o homem todo é o conjunto do homem físico, do homem intelectual do homem cívico e do homem espiritual [...] Ao homem espiritual ensinava os deveres para com Deus, para consigo e para com o próximo; ao homem cívico os deveres com a pátria; ao homem intelectual dá-lhe escolas e cultura; ao homem físico oferece-lhe os meios adequados ao cuidado da saúde, à conservação da robustez, à higienização, à valorização nacional da força muscular (CAVALARI, 1999, p.46-47).

Para o movimento, valores como sacrifício, disciplina, obediência, hierarquia e submissão tinham o intuito de moralizar e regenerar o povo, que deveria estar preparado para servir aos interesses do Estado Integral. O homem deveria ser educado em seus aspectos físico, intelectual, cívico e espiritual (CAVALIERE, 2004). Pela voz de integrantes do movimento, seu projeto é resumido conforme se segue:

Assim, de acordo com o integralismo, a educação integral para o homem integral precisava: evitar a unilateralidade dos sistemas educacionais predominantemente esportivos, científicos, etc. Ela não pode se despreocupar de nenhuma de suas facetas; deve ser física, científica, artística econômica, social, política e religiosa (PAUPÉRRIO e MOREIRA, apud CAVALARI, p.149).

Para Coelho (2005), a espiritualidade, a disciplina e o nacionalismo cívico eram os fundamentos norteadores da educação integral integralista, o que faz com que suas ideias estivessem alicerçadas em uma concepção conservadora. Em resumo, a missão moralizadora e cívica da escola aparece como um modelo de sociedade ultraconservador a ser atingido por meio da educação. Citando Cavaliere:

A educação integral tinha, para Integralistas, o sentido básico de ação doutrinária, posto que entendiam formação como um processo de conversão a uma verdade já estabelecida. Em síntese, eram a concepção doutrinária e, dentro dela, a incorporação da dimensão religiosa à educação escolar as características específicas da educação integral, tal como a entendia o movimento Integralista. (CAVALIERE, 2010, p. 250, grifo da autora).

Como aponta Cavalari (1999), as escolas integralistas eram financiadas pela própria AIB e funcionavam em seus núcleos em âmbito municipal e distrital. Periódicos integralistas da época atestam a existência de ao menos 3000 escolas integralistas em 1937, número expressivo, em nossa opinião. Essas instituições mantinham cursos de alfabetização para todas as idades, além de ensino profissional como corte e costura, enfermagem, datilografia e taquigrafia. Os impressos de propaganda da associação apontavam clara pregação de suas bases por meio da escola: 
Em lugar das crianças freqüentarem escolas atéias, sem técnica profissional e com moldes comunistas, onde o nome de Deus se oculta aos pequeninos, e esquecidos eram os princípios cívicos do amor da Pátria, procurasse o ensino gratuito da escola integralista, lá encontrariam os ensinamentos da idéia sacrossanta de Deus, Pátria, Família (MONITOR INTEGRALISTA apud CAVALARI, 1999, p.73).

Parece-nos que essa concepção de educação integral não menciona o aumento do tempo de escolarização. Contudo, enxergaram a educação como ferramenta central para inculcar seu modelo de conduta e de sociedade nas camadas consideradas incultas e degeneradas. Portanto, para o movimento integralista, caberia a educação integral da mente, do corpo e do espírito, com vistas a uma conversão dos homens pelo ensino, em consonância com valores resumidos na tríplice: Deus, pátria e família.

\subsection{A educação integral e a constituição da república liberal}

\subsubsection{Educação integral: um projeto para o povo}

Um projeto de educação para o povo foi disputa de debates acirrados entre intelectuais nas décadas de 20 e 30. A historiografia da educação relatou com frequência as disputas entre católicos e renovadores ${ }^{9}$ pelo controle das bases da educação no Brasil. Porém, dentro do movimento dos próprios reformadores liberais, ocorreram combates e desavenças sobre o modelo e o intuito da escolarização das camadas populares. A educação estava intrinsicamente vinculada à formação de um homem em consonância com as novas configurações sociais, políticas e econômicas da república. Porém, o que se almejava da educação, e da república, não se consistia em consenso entre os próprios grupos liberais. Nosso objetivo, nesta parte do trabalho, é discorrer sobre as divergências de dois grupos dentro dos núcleos intelectuais da época, são eles: a Liga Nacionalista de São Paulo e a ABE (Associação Brasileira de Educação). Esta última apontava, como modelo de educação, um conceito de educação integral para o povo.

Para Marta Carvalho (2011), o projeto educacional, surgido com a república, pautavase pela regeneração do povo brasileiro, tornando-o saudável, disciplinado e produtivo. A educação tinha um papel central na valorização do homem como fator de produção e de integração nacional. Nessa ótica: “a escola foi, no imaginário republicano, signo da instauração da nova ordem, arma para efetuar o progresso [...] tratava-se de dar forma ao país amorfo, de

\footnotetext{
${ }^{9}$ Ver Saviani, 2011.
} 
transformar os habitantes em povo, de vitalizar o organismo nacional, de construir a nação" (CARVALHO, 2011, p.07). A escolarização do povo brasileiro passa a ter presença nos debates de políticos e de educadores do período. Alguns dos temas de conflito entre os grupos divergentes foram: o aumento da oferta de escolas para alfabetizar a população e a inserção da educação integral. Nesse contexto, o conceito de educação integral aparece como proposta da $\mathrm{ABE}$, em contraposição a formação restrita às letras e números da Liga Nacionalista, visão esta que foi denominada "fetichizaçao da alfabetização" por seus opositores.

A seguir, descreveremos sumariamente o projeto de educação da Liga Nacionalista, que teve como expoente as reformas de Sampaio Dória (1920), no Estado de São Paulo. Ademais, a $\mathrm{ABE}$ propunha outra forma de expansão do ensino por meio do que foi denominado educação integral. Logo, também iremos descrever como esse conceito era entendido, assim como quais seus objetivos e desdobramentos nas políticas de educação do início do século XX.

De acordo com Carlota Boto (1994/1995), o projeto de construção de uma nação era evidente durante a Primeira Guerra Mundial, o que propagou agremiações compostas pelas camadas médias e pela elite, no intuito da composição de uma suposta cultura nacional. Em 1916, por iniciativa de Olavo Bilac, Pedro Lessa e Miguel Calmon, é fundada a Liga da Defesa Nacional, trazendo para a discussão política da época, temáticas como o serviço militar obrigatório e o advento de instituições fortes no intuito da regeneração cívica do povo. A Liga Nacionalista de São Paulo, marcada pelas mesmas bases nacionalistas do período, trazia em seu bojo a difusão da ideia de patriotismo e de construção da nação. Porém, segundo Boto (apud Nagle), seus interesses eram políticos em detrimento de militares (BOTO, 1994-1995). A ideia da Liga pregava a necessidade de universalizar o acesso à educação para consolidar a república liberal, de modo que o voto popular tinha fundamental importância, isto é, a educação teria papel fundamental na criação de cidadão votante em oposição à sociedade oligárquica, pautada no coronelismo. Essa perspectiva foi trazida pela reforma de Sampaio Dória, em São Paulo.

Sampaio Dória, vinculado ao movimento nacionalista de São Paulo, reestruturou a educação, buscando o combate ao analfabetismo no Estado. Conforme Cavaliere, "O analfabetismo era encarado como "doença", pela intelectualidade da época, como o "maior inimigo da Pátria”, e deveria ser combatido heroicamente. Tratava-se de uma cruzada moral.” (CAVALIERE, 2003 p.32).

A reforma de Dória partia de um ideal oposto ao do ensino enciclopédico até então vigente, e, embora propusesse maior difusão numérica da escolarização, o elemento temporal fora sumariamente minorado: apenas duas horas diárias de escolarização gratuita seria garantida à população. Sua reforma objetivava a formação de cidadãos que fossem alfabetizados, 
tivessem uma profissão e cuja formação de caráter estivesse em consonância com o ordenamento social. Para o grupo, a difusão das letras era sinônimo da consolidação da república (CARVALHO,1999). Era proposta uma alfabetização rápida, voltada ao atendimento das demandas recém-impostas pelas novas configurações presentes na recém-industrializada sociedade paulista. Para Cavaliere, a reforma teve efeito progressista e autoritário. Progressista ao propor a erradicação da alfabetização; autoritária, pois, apesar se propor como um projeto antioligárquico "estavam marcados pela proposta autoritária de higienização e regeneração física, moral e social da população brasileira, por meio da qual poderia ser alcançada a disciplina social necessária ao mundo moderno em construção" (CAVALIERE, 2003 p.32). Ainda segundo Cavaliere, a reforma Sampaio Dória prenunciou um problema central que assolou administradores e sistemas educacionais durante todo século XX: o dilema de permanência ou qualidade.

Em oposição ao modelo de educação aligeirada, proposta pela Liga Nacionalista, a ABE vai tecer argumentos a favor do que foi denominado como educação integral. A ABE, surgida em 1924, formou-se por um grupo de intelectuais da época, cuja missão expressa era regenerar o país pela educação. Tinha como integrantes figuras como Heitor Lira, José Augusto e Antônio Carneiro Leão, assim como Lourenço Filho e Anísio Teixeira. A ABE era um órgão apolítico que tinha como objetivo reunir todos os interessados pela educação nacional, independentemente de doutrinas filosóficas ou religiosas, o que reuniu desde ateus como Edgar Sussekind de Mendonça até líderes católicos como Fernando Magalhães (SAVIANI, 2011).

A associação, ao longo dos anos 20, promoveu várias conferências nacionais que influenciaram as reformas estaduais ocorridas na época após a de Dória. Seu objetivo central era, na visão de Romanelli (1978), sensibilizar a opinião e o poder público para os problemas mais cruciais da educação nacional, além da necessidade de adotar medidas eficazes para a solução dos problemas da educação. Em outras palavras: o grupo tinha como desejo difundir seu pensamento para implementar as reformas que enxergava como necessárias para o ensino: a educação ideal para o povo era a integral. Para a ABE, a educação deveria estar vinculada a um projeto de construção do homem nos moldes da república e, portanto, a escola estava incumbida de moralizar, sanear e unificar o povo e seus costumes. A escola era espaço privilegiado para a renovação das condutas, para a implantação de hábitos de trabalho e de valores cívicos; ou seja, a educação integral tratava-se da "educação do sentimento, dos gestos, do corpo e da mente" (CARVALHO, 1989, p.59).

Conforme Carvalho, para os membros da $\mathrm{ABE}$, era preciso, ao invés de "apressadamente ensinar a ler, escrever e contar aos adultos iletrados, cuidar seriamente de 
educar-lhes os filhos fazendo-os frequentar uma escola moderna que instrui e moraliza, que alumia e civiliza" (CARVALHO, 2003, p. 213). Nessas bases, a educação integral, em oposição à "fetichização da alfabetização" do grupo de Dória, propunha uma escola que ampliasse suas funções sociais. Para Heitor Lyra, líder da ABE:

O levantamento do nível popular tem que repousar sobre tríplice base: moral, higiênica e econômica, o que significa que sem cultura das qualidades do caráter, sem a melhoria das condições de saúde da massa da população e sem uma racional organização do trabalho é utopia esperar que a alfabetização rápida e quase instantânea, se possível, viesse a transformar para o bem as atuais condições do país (Lyra Apud Carvalho, 1988, p.46).

Assim, essa primeira concepção de educação integral liberal parte da noção de que seria papel das elites formar o povo inculto de acordo com os preceitos da modernidade e do progresso, advindos das transformações socioeconômicas da república. Carvalho (1998) aponta as enormes diferenças com que eram tratadas a educação popular e a educação das elites. Enquanto a primeira previa apenas o ensino básico sustentado no tripé "saúde, moral e trabalho", a segunda era objeto de discussões calorosas em torno da universidade e do ensino secundário. Era uma educação de duplo percurso, uma para formar um "homem integral" de acordo com as necessidades do projeto republicano brasileiro para as massas, e outra para formar os quadros da elite dirigente.

As reformas Estaduais de ensino que surgiram após a de Sampaio Dória tomaram como fundamento as críticas do "fetichismo da alfabetização" como modelo de educação para o Brasil: a de Lourenço Filho no Ceará (1923), a da Anísio Teixeira na Bahia (1925), a de Fernando Azevedo no distrito Federal (1928) e a de Carneiro Leão em Pernambuco (1928). ${ }^{10}$ A redefinição da escola nos moldes na $\mathrm{ABE}$ compreendia elementos como o ensino técnico, métodos pedagógicos novos, seleção de aptidões e encaminhamento profissional. Suas propostas buscavam um ideal civilizatório que estaria embasado na valorização de temas como a saúde, a moral e a profissionalização. A Reforma de Lourenço Filho, por exemplo, convencia o professorado de que a escola não devia limitar-se a ensinar a ler, a escrever e a contar, mas deveria abrir espaço para a educação moral e para o desenvolvimento de aptidões físicas por meio de um currículo capaz de "educar o corpo e harmonizar o espírito por meio de exercícios físicos: o desenho, os trabalhos manuais, os jogos, o escotismo e a ginástica sueca" (CARVALHO, 2000, p.235).

\footnotetext{
${ }^{10}$ Está fora do alcance deste trabalho tratar as especificidades de cada uma dessas reformas.
} 
A inovação das práticas pedagógicas que tornaram as conferências da $\mathrm{ABE}$ conhecidas, já nos anos 30, tiveram como ponto de partida o pensamento de Anísio Teixeira. Conforme Cavaliere (2002), em 1927, o educador baiano fez viagem aos Estados Unidos e participou de uma série de cursos na Universidade de Columbia. Em solo estrangeiro, tomou contato com as obras de Dewey e W. H Kilpatrick, obras que marcaram suas bases teórico-filosóficas. A partir da inserção dessas bases epistemológicas na AEB, por intermédio, principalmente, de Anísio Teixeira, a educação e a educação integral adquirem novas conceituações. Carvalho (1989) lança a hipótese de que fora o americanismo de Anísio o responsável pelas mudanças que sofreram as ideias pedagógicas no período. Na visão de Cavaliere (2002), o pensamento de Anísio, embasado em Dewey, superou a visão cívico-sanitária da educação e, assim, abriu-se território para outras bases de pensamento das práticas pedagógicas em conformidade com a pedagogia moderna.

As reformas do período foram influenciadas por um movimento de renovação educacional que pretendia reformular as práticas pedagógicas de acordo com a restruturação das forças produtivas no período. Todavia, com a disseminação das ideias da pedagogia moderna, o período foi marcado por intensas contradições. Segundo Cavaliere (2002), esse cenário é marcado por ambiguidades que coexistiram nos pensadores liberais do período e evidenciaram uma convivência contraditória de maneiras de enxergar a escolarização popular. A autora aponta:

Uma visão radicalmente liberal e um liberalismo elitista ainda "curativo e "domesticador" b) a escola com funções formativas e culturais ampliadas e a escola meramente alfabetizadora c) A busca da qualidade da educação e a urgência da expansão, isto é, a urgência do crescimento quantitativo dos sistemas escolares. (CAVALIERE, 2002 p.251).

Assim, a pedagogia moderna recebeu diversas nomenclaturas: Escola Ativa, Escola Funcional e Escola Progressiva, sendo amplamente conhecida como Escola Nova. Pretendiase a renovação dos processos educacionais a partir de estudos da biologia, da psicologia e da sociologia. Esse movimento ficou conhecido pela oposição à chamada Escola Tradicional, que havia marcado as práticas de ensino até então. Nosso intuito, nesta parte do trabalho, é trazer algumas das concepções da chamada Escola Nova. Foi pela disseminação dessas ideias que a educação integral em tempo integral sustentou seus fundamentos na maioria das experiências brasileiras. Para Cavaliere (2002), a compreensão pela qual se desenvolveu a concepção de educação integral no Brasil passa, necessariamente, pelas ideias pedagógicas escolanovistas do começo do século XX. 


\subsubsection{A escola nova e o surgimento de um modelo de Educação Integral}

A revolução de 30 destruiu o monopólio do poder pelas velhas oligarquias, o que criou algumas das condições essenciais para o crescimento do capitalismo industrial. A industrialização, segundo Romanelli (1978), não significou uma total destruição da velha estrutura econômico social da república velha, mas expandiu as necessidades de escolarização do povo para servir de força de trabalho nesses novos setores da modernidade. Essa nova ordem social e econômica e a emergência de novas camadas sociais criou também um aumento expressivo da demanda da população pela escola, o que gerou uma mudança cultural no nível de aspiração da sociedade por educação. Em 1930, é criado o ministério da Educação e Saúde, e, logo em seguida, em 1931, é promulgada a Reforma Francisco Campos ${ }^{11}$, que marcou a ação do Estado na educação. Era a primeira vez em que uma reforma de ensino atingia todo o território nacional.

Conforme Carvalho (1994), em 1931, a ABE alcançou a projeção que almejava. Essa projeção foi alcançada com um pedido de Vargas e Francisco Campos para que o grupo fornecesse a "fórmula feliz" e o "conceito de educação" que iria respaldar o governo provisório. Segundo Saviani (2011, p. 230), “o governo buscava legitimação para a sua política educacional; e o grupo que dirigia a ABE buscava, por sua vez, abrir espaço no aparelho do Estado para consolidar sua hegemonia sobre o campo educacional”. Assim, por meio das reuniões da ABE, partiu-se a iniciativa de escrever o Manifesto dos pioneiros da Educação Nova (1932), documento que disseminou as bases das concepções de um grupo de educadores dentro da ABE, ficando conhecidos como 'pioneiros da Escola Nova'. Essas ideias marcaram profundamente a educação no Brasil até os dias de hoje.

As concepções de educação, difundidas pelo movimento da Escola Nova, marcaram gerações de educadores e mudaram a forma de compreender a escola e as práticas pedagógicas. Foi na esteira dessas ideias que surgiu no Brasil a discussão de um modelo de educação integral, alinhado à preocupação com o tempo adequado de escolarização, segundo os preceitos das novas pedagogias. Ou seja, surgiu-se a ideia de 'escola de dia inteiro', ou seja, de uma escola integral em tempo integral.

A influência dos Estados Unidos e da Europa marcaram o pensamento dos educadores brasileiros das décadas de 20 e 30. Segundo Cavaliere (2002), uma série de experiências educacionais escolanovistas de educação em tempo integral foram desenvolvidas durante todo

${ }^{11}$ Ver Romanelli (1978) e Saviani (2011). 
o século XX. Entre elas, "escolas de vida completa" inglesas; os "lares de educação no campo" e as "comunidades escolares livres" na Alemanha; a "escola universitária" nos EUA; as "casas das crianças" orientadas por Montessori, na Itália; a "casa dos pequenos", criada por Claparède e Bovet, em Genebra e a "escola para a vida", criada por Decroly em Bruxelas. Apesar das particularidades de cada uma dessas experiências, Cavaliere aponta que todas partiam de certas concepções em comum, como: "a articulação da educação intelectual com a atividade criadora [...] à vida social-comunitária da escola, à autonomia dos alunos e professores" (CAVALIERE, 2002, p.251).

A pedagogia nova tem como alvo sua antecessora pedagogia tradicional, baseada na transmissão de um conhecimento enciclopédico por meio de uma relação entendida como autoritária, na qual o professor é detentor único de um conhecimento a ser transmitido ao aluno. A Escola Nova, por outro lado, entendia o educando como centro da ação pedagógica. Se antes, para a pedagogia tradicional, o processo pedagógico era centrado no professor e na transmissão de certos conteúdos definidos em um currículo, para a nova tendência, a atividade dos alunos assumia protagonismo. Os estudiosos da Escola Nova, pautados nos referenciais da psicologia e da sociologia, defendem que a ação pedagógica deve obedecer às diferenças psicológicas e, assim, se embasavam em uma nova visão de criança e de aprendizado. Na concepção da Escola Nova, existe uma grande valorização da organização do trabalho coletivo dentro da escola, além da preocupação em fornecer um atendimento especializado que leve em consideração as especificidades de cada indivíduo.

Cavaliere destaca que o movimento escolanovista trouxe

“[...] novas ideias em educação que questionavam o enfoque pedagógico até então centrado na tradição, na cultura intelectual e abstrata, na autoridade, na obediência, no esforço e na concorrência. Para os reformistas, a educação deveria assumir-se como fator constituinte de um mundo moderno e democrático, em torno do progresso, da liberdade, da iniciativa, da autodisciplina, do interesse e da cooperação. As reformas nas instituições escolares visavam à retomada da unidade entre aprendizagem e educação, rompida a partir do início da era moderna, pela própria escolarização, e buscavam religar a educação à "vida." (CAVALIERE 2002 p.252).

Conforme Cavaliere (2002), as experiências da Pedagogia Nova tiveram como referencial principalmente Claparède, Montessori, Decroly, Dewey e Freinet. O sentido geral de cada um desses pensadores é o "de criação de canais de comunicação e interferência entre os conhecimentos formalizados e as experiências práticas cotidianas da vida" (CAVALIERE, 2002, p.255). Para a autora, apesar das diferenças que marcaram cada movimento específico da pedagogia Nova, todos tinham a expectativa de "alcançar o renascimento social a partir de um 
homem novo, de uma nova geração, formada segundo essas bases escolares”. (CAVALIERE, 2002, p.255). A escola, nesta perspectiva, seria a grande responsável pelas mudanças na mentalidade do povo, que constituiriam, assim, uma sociedade mais justa e democrática pautada no liberalismo clássico.

Como já nos referimos anteriormente, as ideias de Dewey, trazidas por Anísio Teixeira, no final na década de 20, foram fundamentais para os movimentos escolanovistas no Brasil. Segundo Cavaliere (2002), uma das principais contribuições desse pensamento está na ideia de que a escola é o agente principal na instituição da democracia. Partindo do pensamento de Dewey e de seu conceito de "experiência", uma das principais funções da escola é a de propiciar experiências democráticas na escola de modo a construir cidadãos alinhados a esse conceito. A escola não prepararia para a vida, ela incutiria em suas práticas experiências educativas de vida. Nas palavras de Cavaliere, "Para o pensador americano, é preciso que a vida escolar seja uma seleção daquelas experiências que possam constituir "modelos vivos" de uma sociedade almejada" (CAVALIERE, 2002, p.259).

Na visão de Patto (1984), as propostas de Dewey para a escola têm como pilar central a ideia liberal do mito da igualdade de oportunidades, garantida pela educação promovida pelo Estado. A autora aponta que,

Em suma, a educação formal é considerada um forte fator de construção de uma sociedade aberta, e um fator neutralizador, viabilizado pelo Estado, das desigualdades sociais. Seus propositores partem, portanto, da aceitação da sociedade de classes como sociedade ideal e da crença na possibilidade de igualdade de oportunidades sociais numa sociedade onde vigora o modo de produção capitalista. (PATTO, 1984, p.24).

Para os liberais, a justiça social seria promovida por meio da escola pública gratuita, obrigatória e igualitária. Segundo Patto, Dewey entende que a educação seria responsável por produzir um homem "plenamente desenvolvido", que seria aquele que utiliza suas capacidades individuais inatas para o desenvolvimento da sociedade. A educação para Dewey ocorre em vistas a alcançar uma sociedade ideal, isto é, a sociedade democrática. O cidadão democrático seria aquele que "desenvolve o melhor de si e o aplica conscientemente em nome de um fim o bem comum" (PATTO, 1984, p.25).

Conforme Patto (1984), Dewey, chega contestar as mazelas da sociedade de classes, porém, não traz em seus argumentos um caráter estrutural; pelo contrário, enxerga, muitas vezes, a estrutura econômica e política do capitalismo como saudáveis ao bom ordenamento da vida. Além disso, para Dewey, os desvios do ideal de democracia são consequências pessoais, 
portanto, erros de conduta, como no caso da criminalidade, isto é, são questões de cunho moral individual. Patto aponta que as mudanças sociais que Dewey idealiza, por meio da educação para a democracia, caracterizam-se pela "maior permeabilidade nas barreiras que separam rigidamente as classes de modo a tornar mais justa a ascensão social e mais rico intercâmbio entre as classes" (PATTO, 1984, p.26). Portanto, uma visão integradora e não contestadora do modelo capitalista.

O ideário escolanovista brasileiro, contido no manifesto dos pioneiros da educação, advogou a laicidade, a gratuidade e a obrigatoriedade do ensino público. Sendo assim, seria dever do Estado garantir e organizar a educação para todos os cidadãos, independentemente de sua origem social. Saviani (2011), em comentário ao manifesto de 1932, relata que a originalidade do movimento reformador brasileiro foi sua defesa da escola pública, pois em outros locais, como Europa e Estados Unidos, as experiências escolanovistas ocorreram na esfera privada. Para o autor, em comentário à posição de Luis Antônio Cunha, o manifesto da escola nova apresentou aspectos elitistas e igualitários. Elitista ao aproximar-se das visões de pensadores como Durkheim ${ }^{12}$; igualitárias ao referir-se às concepções socialistas de escola ou ao aproximar-se da vertente liberal-igualitarista de Anísio Teixeira.

Carvalho (1998) aponta que o movimento da Escola Nova, no Brasil, só chegou nas primeiras décadas do século XX, diferentemente da Europa, onde surgiu como crítica de um modelo escolar já implementado. Sendo assim, esse movimento no Brasil, além de tardio, chega em contexto oposto, uma vez que a constituição do ensino público ainda estava em discussão. Para a autora, a entrada da ABE no cenário educacional significou a repolitização da educação, à medida que muitos de seus integrantes ampliaram o espaço da política ao assumir postos na administração estatal. Para Romanelli (1979), a pedagogia dos reformadores da época era exclusivamente contrária à escola tradicional, e não contrária ao sistema burguês, pois o movimento renovador estava em total consonância com a ordem social e econômica que se implantava por meio do capitalismo industrial.

Para Saviani (2006), a inovação pedagógica proposta pela Escola Nova no Brasil ocorre dentro do conservadorismo que buscou controlar as crescentes massas escolares por intermédio do discurso neutro da ciência. Segundo o autor, a hipervalorização do papel da escola estaria intimamente ligada ao controle dos cidadãos pelo Estado, em uma inserção do liberalismo

\footnotetext{
12 Patto (1985) aponta que Durkheim, partindo de modelos biológicos, enxerga as sociedades complexas com um organismo. Em uma sociedade orgânica, a divisão social do trabalho preenche as funções necessárias para o bom funcionamento do organismo, o que supõe indivíduos diferentes entre si. Nesta sociedade, a educação tem a missão de construir um ser solidário e submisso às exigências sociais, a educação deve ter caráter uno- uma base comum, e múltiplo- para atender a diversidade e as aptidões distintas para funcionarem no sistema orgânico.
} 
conservador em consonância com o capitalismo, no qual suas imperfeições e conflitos sociais deveriam ser mascarados pelo discurso científico, isto é, pela racionalização da vida.

Cavaliere (2004), em defesa ao movimento da Escola Nova, advoga que, no caso brasileiro, os mecanismos de exclusão das classes populares das escolas, como as reprovações, os conteúdos rígidos e à rejeição às diferenças culturais, são elementos da pedagogia tradicional. As ideias pedagógicas da Escola Nova foram promissoras à medida que demonstraram uma preocupação real na instituição da democracia, não como arranjo de ideias a favor do capitalismo, mas como fator político em direção a uma sociedade melhor. No dizer da autora, "a redução de um amplo e consciente movimento de questionamento do instituído a uma estratégia de controle das classes dominantes sobre as classes "perigosas" nos parece imprópria" (CAVALIERE, 2004, p.254). Em sua visão, o capitalismo não acolheu essa visão de escola que requeria investimentos muito maiores, o que faria com que o controle centralizado fosse quebrado, contribuindo, assim, para o surgimento de novas mentalidades.

Saviani (2003), de certa forma, concorda neste último ponto com Cavaliere. Para o filosofo, o escolanovismo, na sociedade capitalista, foi um modelo viável apenas para as elites na medida em que necessita de um ambiente adequado e equipado, além de um pequeno número de alunos para seu sucesso, o que depende de grandes investimentos financeiros que não foram disponibilizados, com exceção de algumas experiências pontuais, que ocorreram no formato de "escolas experimentais ou como núcleos raros, muito bem equipados e circunscritos a pequenos grupos de elite" (SAVIANI, 2003, p.9).

Conforme Saviani (2006), os Pioneiros da Educação Nova inspiraram as gerações seguintes. A partir do lançamento do manifesto de 1932, suas concepções de teoria da educação, de política educacional, assim como de prática pedagógica, influenciaram educadores e sistemas de ensino, o que indicou a crescente penetração do ideário renovador na educação brasileira. O autor afirma que, mesmo após o fim do Estado Novo, o ideário renovador consolida-se como hegemônico. Portanto, as ideias da Escola Nova formaram a concepção de educadores e delinearam políticas públicas. Além disso, foram presentes nas mais significativas experiências de educação integral no Brasil: os centros educacionais Carneiro Ribeiro ou as Escolas Parques, de Anísio Teixeira; os CIEPS e o Programa Mais Educação. 


\subsubsection{Os centros educacionais carneiro ribeiro: uma experiência grandiosa para poucos}

Os Centros Educacionais Carneiro Ribeiro (CECR) são considerados, ainda hoje, a grande referência de educação integral em tempo integral no Brasil. Parece-nos que a vinculação da ideia de tempo integral (ou escola de dia todo), com a educação integral, tem como gênese a escola implementada por Anísio Teixeira, sob as bases da pedagogia nova - da qual era defensor. Convidado por Otávio Mangabeira, governador da Bahia (1946-1950), para a secretaria de Educação e Saúde, Anísio Teixeira constatou a oportunidade de colocar em prática um modelo de educação que é lembrado como uma experiência pioneira.

Segundo Cavaliere (2010), Anísio foi um grande defensor do aumento da jornada escolar. Ainda nos anos 30, propôs um aumento significativo da carga horária escolar diária e do número de dias letivos por ano. Para o educador, a jornada de 640 horas anual deveria ser substituída por outra de 1080 horas, isto é, 180 dias letivos de seis horas. Na visão de Teixeira, segundo Cavaliere, e educação primária deveria ser circunscrita nas seguintes premissas: “a) manter e não reduzir o número de séries escolares; b) prolongar e não reduzir o ano letivo; c) enriquecer o programa com atividades educativas, independentes do ensino propriamente intelectual; d) preparar um novo professor para as funções mais amplas da escola" (CAVALIERE, 2010, p.258). Conforme a autora, Anísio não utilizou o conceito de educação integral por considerá-lo vago e para que não fosse confundido à propaganda integralista que o utilizava fartamente. Em nossa visão, talvez, Anísio também quisesse se distanciar das concepções de educação integral sanitária e cívica dos liberais da ABE, da década de 20.

Para Clarice Nunes (2009), Anísio, além de ter posições contrárias ao encurtamento escolar, também não compartilhava da perspectiva de ensino dualista, como propunha as leis orgânicas de Ensino de Gustavo Capanema (1942) ${ }^{13}$. Conforme a autora, para Anísio, "a escola primária deveria oferecer aos estudantes oportunidades amplas de vida, compreendendo atividades de estudar; de trabalho; de sociabilidade, de arte, de recreação e jogos" (NUNES, 2009, p.123).

\footnotetext{
${ }^{13}$ Segundo Romanelli (1978), as leis orgânicas do ministro da Educação de Vargas, no período do Estado Novo, eram caracterizadas pela cristalização de uma dualização dos sistemas de ensino. O ensino secundário era divido entre Curso Científico e Curso Clássico, que já, desde cedo, definiam os percursos escolares dos estudantes rumo às carreiras universitárias. $\mathrm{O}$ curso universitário só poderia ser cumprido de acordo com o curso secundário escolhido. Para as populações desfavorecidas, em atendimento às demandas da industrialização, é criado o ensino técnico ou profissionalizante, por meio do Serviço Nacional de Aprendizagem Industrial (SENAI) (1942) e do Serviço Nacional da Aprendizagem Comercial (SENAC) (1946). Espanta-nos a similaridade da referida proposta com a reforma do Ensino Médio proposta atualmente (2017) pelo MEC.
} 
Em 1950, o CECR foi inaugurado em um bairro popular da capital baiana. Foram construídos prédios conjugados - as escolas-classe e as escolas-parques - que garantiriam uma educação em dois turnos. Anísio idealizara nove Centros de Educação Popular, todavia, apenas um se concretizou. A escola atendia crianças dos 7 aos 15 anos, das 7:30 às 16:30. O estudante, nesse período, além das atividades educativas, se alimentava e tomava banho. O número de crianças por educador era de no máximo vinte. A permanência na escola seria de 7 anos ao todo e a reprovação foi abolida. $O$ projeto, ainda, previa a criação de residência para $5 \%$ dos menores considerados sem lar. (CAVALIERE, 2010); (NUNES, 2009).

Nas escolas-classe eram desenvolvidos o ensino das letras, matemática, ciências e estudos sociais. Constituam-se quatro escolas que funcionavam em dois turnos e abrigavam 500 alunos por período, isto é, 1000 por escola. Cada prédio consistia-se em um conjunto de 12 salas de aula, destinadas à instrução e à administração, além de áreas cobertas, bem como gabinetes dentários e médicos, jardins, hortas e áreas livres. As escolas-parque eram o local onde as crianças completavam sua formação no contra turno e eram compostas dos seguintes setores: (a) pavilhão de trabalho; (b) setor socializante; (c) pavilhão de educação física, jogos e recreação; (d) biblioteca; (e) setor administrativo e almoxarifado; (f) teatro de arena ao ar livre e (g) setor artístico. (ÉBOLI apud CAVALIERE, 2010). Assim, as atividades das quatro escolas-classe complementavam-se no contra turno nas escolas-parque. Como aponta Nunes (2009), as atividades desenvolvidas nas escolas-parque eram organizadas por faixa etária e por áreas do interesse do estudante, as atividades fornecidas eram:

a) artes aplicadas (desenho, modelagem e cerâmica, escultura em madeira,
cartonagem e encadernação, metal, couro, alfaiataria, bordados, bijuterias,
tapeçaria, confecção de brinquedos flexíveis, tecelagem, cestaria, flores) no
Setor de Trabalho; b) jogos, recreação e ginástica no Setor de Educação Física
e Recreação; - grêmio, jornal, rádio-escola, banco e loja no Setor Socializante;
c) música instrumental, canto, dança e teatro no Setor Artístico; d) leitura,
estudo e pesquisas no setor de Extensão Cultural e Biblioteca. (NUNES, 2009,
p.126).

Os Centros de Educação Carneiro Ribeiro foram alvo de elogios, e também, de duras críticas como relatou a imprensa baiana da época. A principal crítica era a comparação, das escolas de Anísio, com as demais do Estado, estas últimas em condições precárias e sucateadas. Outro ponto dos opositores era o grande investimento financeiro que requeria para a construção e manutenção do projeto. Os elogios vinham, principalmente, em relação ao projeto arquitetônico e em relação às concepções pedagógicas na qual o modelo era baseado (CAVALIERE, 2010). Nunes (2009) aponta que os centros populares de educação receberam 
visitas de representantes da ONU e da UNESCO, consequência da repercussão da experiência que atingiu âmbitos internacionais.

Cabe ainda ressaltar que, na década de 60, Anísio participou da formulação do plano piloto da capital do país, recém-inaugurada. As escolas de Brasília tiveram como modelo os centros de Educação popular Carneiro Ribeiro, que Anísio almejava como modelo de educação para todo o país.

A experiência das escolas-parque orientou os modelos de educação integral subsequentes e é considerada um modelo ideal para muitos autores. Na visão de Nunes (2010 p.126), o Centro Educacional pretendia "integrar os alunos na comunidade escolar; torná-los conscientes dos seus direitos e deveres e desenvolver com eles atitudes de autonomia, iniciativa, responsabilidade, cooperação, honestidade, respeito por si mesmo e pelos outros". Para Cavaliere (2010, p.258), a base da concepção que guiou a formulação de Anísio é: "resumidamente, o entendimento de que educação é vida e não preparação para a vida; o entendimento de que as demais instituições sociais perderam parte de suas capacidades educativas, que devem então ser supridas pela escola; e a busca da escola verdadeiramente “comum", isto é, democrática".

Freitas e Galter (2006); (2007) analisam os CECR a partir de outra perspectiva. Para os autores, a experiência anuncia um modelo de educação integral em que as funções sociais da escola são ampliadas e têm, como objetivo primordial, ações assistenciais que seriam responsabilidade de outras instâncias. A escola teria aumentado suas demandas sociais deixando as questões pedagógicas em segundo plano. Nessa visão, a experiência baiana não se caracterizaria como educação integral, mas como educação integrada, isto é, uma escola que tem como papel central o combate aos problemas sociais característicos da exploração capitalista (violência, miséria, desnutrição). Na voz dos autores:

[...] percebemos que as idéias de Anísio Teixeira implantadas no CECR não são de uma educação integral, mas de uma educação integrada, ou seja, é uma escola preocupada explicitamente em integrar outras funções sociais (saúde, segurança etc.). Esse ensaio merece uma atenção especial, pois muitos dos elementos criados na experiência baiana são percebidos nas experiências de jornada escolar prolongada realizadas atualmente (FREITAS E GALTER, 2007, p.128-129, grifo do autor).

Para Anísio Teixeira, a escola era considerada o meio mais importante de justiça social e de promoção da igualdade. Anísio idealizou uma "escola única" em que a mesma escola pública atenderia todas as camadas sociais na formação de um cidadão comum para a 
democracia, o que, em sua visão, traria a garantia da igualdade de oportunidades. Seu sonho não se concretizou e o modelo de escolarização que proliferou no Brasil foi a escola pública para os pobres e a escola particular para os extratos médios e altos da sociedade. A educação integral passou a ser vista como modelo de formação ideal das populações de baixa renda, entendida por uns como o meio de garantia da igualdade de oportunidades e justiça social, e enxergada por outros - pautados nos ideias neoliberais - como maneira de aliviar as tensões sociais e promover a regeneração moral para que os pobres ocupem os lugares que lhes são reservados, os empregos subalternos e de baixa remuneração.

Em suma, os Centros de Educação Popular Carneiro Ribeiro propuseram uma educação para além da tradicional, por meio da integração das disciplinas comuns do currículo, com atividades que tinham a missão de propiciar uma educação socializadora e profissionalizante, isto é, uma escola que aumentou suas funções sociais a partir de uma percepção de que, para educar integralmente, é necessário mais tempo na escola. Essas concepções marcaram intensamente as experiências de educação integral vindouras, como no caso dos CIEPs no Estado do Rio de Janeiro.

\subsubsection{Os centros Integrados de Educação Pública (CIEPS)}

Os Centros Integrados de Educação Pública (CIEPs) foram desenvolvidos por Darcy Ribeiro, no governo de Leonel Brizola. O período foi marcado pelo processo de abertura democrática do país e pela realização de eleições diretas para governador, que levaram à ascensão governos de oposição ao regime militar. Para Saviani (2011), desde as eleições municipais de 1976, multiplicaram-se as iniciativas de educação voltadas para crianças e jovens das camadas populares, tanto em âmbito municipal como estadual.

Dentre os programas preocupados com a reformulação do modelo de escolarização das classes populares estavam os CIEPs, uma rede de escolas públicas em tempo integral em todo estado do Rio de Janeiro. Ao longo das duas gestões de Leonel Brizola (83/86) (91/94), foram construídos 506 CIEPs no contexto dos $1^{\circ}$ e $2^{\circ}$ Programas de Educação Especial (PEE), realizados um em cada mandato de Brizola. A experiência teve forte influência dos CERC, de Anísio Teixeira.

O projeto idealizado por Darcy Ribeiro entendia um projeto de escola integral, com base no projeto de escola para a democracia; e de tempo integral, no qual o estudante fica o dia todo em atividades propostas pela escola. Segundo Darcy Ribeiro, o objetivo central dos CIEPs era trazer uma escola de qualidade para as populações desfavorecidas: 
A diretriz básica do Programa é a recuperação da Escola pública melhorandoa e colocando-a efetivamente ao encalce de todas as crianças e jovens do Estado. O grande objetivo, a ser cumprido dentro do quadriênio do mandato governamental, é consolidar um ensino público moderno, bem aparelhado e democrático, capaz de ensinar todas a crianças a ler, escrever e contar, no tempo devido e com a correção desejada. (RIBEIRO, 1986, p.35).

Sob uma visão liberal, Darcy Ribeiro acreditava que a educação era a peça fundamental para o desenvolvimento da nação. Sua concepção de educação integral partia da vontade de entregar às camadas populares o benefício de uma escola como a das elites, para garantir, assim, a igualdade de oportunidades. Em sua visão, a "escola pública, aberta a todos, em tempo integral, era a receita para iniciar as crianças nos códigos de sociabilidade, tratamento, relacionamento e preparo para a vida em sociedade" (BOMENY, 2009, p.114). Para Maurício (2004), a proposta de Ribeiro baseava-se em experiências internacionais de educação em tempo integral, em que a escola tem a função de acolher as crianças das camadas populares contra o abandono das ruas ou a falta de assistência familiar. Essas situações faziam com que a infância fosse interrompida pela entrada precoce no mercado de trabalho. Sendo assim, caberia à escola a função protetora e integradora dessas crianças e jovens na civilização moderna.

Segundo Maurício (2004), as escolas projetadas por Oscar Niemayer atendiam durante o dia todo 600 crianças, além de 400 à noite. As aulas eram compostas pelas disciplinas do currículo e por atividades esportivas e recreativas, possuía acesso a uma biblioteca e contava com sala de vídeo, além de propiciar participação em atividades culturais. Havia também atendimento odontológico e preocupação com a alimentação e com hábitos de higiene. As escolas foram pensadas para atender às populações de baixa renda e estavam localizadas, em sua maioria, nas regiões mais pobres. A estrutura física do projeto era composta por prédio de três blocos, contendo o prédio principal três andares, além disso, possuía

[...] as salas de aula, um centro médico, a cozinha e o refeitório, além das áreas de apoio e de recreação. No segundo bloco, fica o ginásio coberto, com sua quadra de vôlei/basquete/futebol de salão, arquibancada e vestiários. Esse ginásio é chamado de Salão Polivalente, porque também é utilizado para apresentações teatrais, shows de música, festas etc. No terceiro bloco, de forma octogonal, fica a biblioteca e, sobre ela, as moradias para alunos residentes. (RIBEIRO, 1986, p.42).

Em cada um dos PEE, havia uma concepção referente à disposição dos horários das atividades diversificadas. O primeiro partia de uma organização similar aos CECR, em que, em uma parte do período, realizavam-se as atividades do currículo e, no outro tempo, as atividades 
de cultura, lazer e esporte. Para Cavaliere (2002, p.102), essa primeira formulação "trouxe o problema da reafirmação de uma hierarquia entre as atividades, as da sala de aula como sendo as realmente importantes". O segundo PEE propôs que todas as atividades fossem intercaladas nos dois turnos, o que, na visão da autora, é uma forma "adequada à criação, dentro da escola, de um processo de valorização e ressignificação, para a vida escolar, das atividades artísticas, esportivas e culturais em geral". Numa comparação entre os CECR e os CIEPs, enquanto na primeira experiência as atividades curriculares e complementares ocorriam em períodos e prédios distintos; na segunda, Darcy Ribeiro, a partir do segundo PEE, entende que todas as atividades devem acontecer ao longo do período de permanência na escola e em um único prédio.

O primeiro CIEP foi inaugurado em 1985, recebeu o nome de Tancredo Neves, homenagem ao falecimento do presidente recém-empossado após anos de ditadura militar. Cerca de 200 CIEPs foram implantados na primeira gestão de Brizola, porém só entraram em funcionamento no último ano de governo, pois serviram de plataforma de campanha de Saturnino Braga para a prefeitura do Rio de Janeiro. A eleição de Moreira Franco, para o governo do Estado, inviabilizou a continuidade do programa, com uma redução drástica das verbas para o projeto. Com o segundo mandato de Brizola, o projeto foi recuperado e foram entregues mais 400 CIEPs (entre novos e recuperados), atingindo a meta estipulada de 500 unidades. A maior parte dos CIEPs foi entregue nos dois últimos anos de governo, sendo grande parcela nos últimos meses. Com a entrada de Marcelo Alencar para o governo do Estado, mais uma vez, a política sofre descontinuidade (MAURÍCIO, 2002, 2004).

Com o duplo desmonte, as escolas de tempo integral, especialmente as da região do Grande-Rio, tornaram-se, "escolas abandonadas, confusas, problemáticas, rejeitadas pelo próprio sistema, sem projeto e sem condições de administrar sequer seu espaço. Foram assim estigmatizadas como escolas para crianças sem cuidados familiares, semimarginalizadas" (CAVALIERE, 2002, p.100). Os CIEPs foram um exemplo da descontinuidade das políticas públicas em educação no Brasil, com base nas mudanças de governos e revezamento de partidos políticos no poder.

A massificação do modelo de educação em tempo integral no Rio de Janeiro foi alvo de polêmicas e controvérsias. Maurício, a partir de um estudo da arte sobre pesquisas que tomaram os CIEPs como objeto de estudo, aponta que existem dois blocos sobre o assunto, um favorável e outro contrário à sua implantação. Os opositores da experiência Lobo (1988), Mignot, (1988), Paro (1988) e Cunha (1994), têm as seguintes críticas: a) Aspecto populista e clientelista que revelou maior preocupação eleitoral que educacional; b) Qualidade precária do ensino público, 
o que impossibilitava uma expansão da jornada no momento; c) Altos custos da construção e manutenção da escola em tempo integral, o que dificultava a universalização do ensino fundamental; d) Caráter assistencialista da proposta; e) Construções como carro-chefe da propaganda eleitoral de Brizola, sendo as escolas apelidadas de "Brizolão".

Cavaliere (2002, p.95) articula-se ao grupo dos favoráveis e, em resposta aos opositores dos CIEPs, argumenta que "tais interpretações, embora trazendo luz sobre questões a serem consideradas, ainda não deram conta, nos parece, de uma compreensão mais profunda dos efeitos concretos, políticos-pedagógicos, que a experiência teve para a educação do estado". Apesar de concordar com os empasses políticos que inviabilizaram uma experiência de sucesso, para autora, os CIEPs trouxeram inovações importantes para a cultura e estrutura organizacional da escola, no que tange a utilização do tempo e espaço escolar e a articulação do trabalho pedagógico. Alguns dos aspectos positivos apontados são: as tentativas de reformulação do currículo; a construção de prédios apropriados e bonitos sem barreiras ou grades; a organização do trabalho pedagógico coletivo cotidiano que incorporou horário de estudo e planejamento semanal para os professores.

Para Helena Bomeny (2009, p.117), o sonho de Darcy Ribeiro era que os CIEPS também se concretizassem a escola das classes médias. Contudo, "a ênfase dada em todos os discursos na prioridade, para o programa, das classes populares e da população da periferia criou um vínculo simbólico entre clientela pobre e clientela dos CIEPS”. A grande quantidade de escolas em tempo integral construídas nas duas gestões de Brizola fez com que, na visão da autora o CIEP se consolidasse como "referência para qualquer discussão sobre escola em tempo integral, confundindo-se completamente com o seu ideário" (BOMENY, 2009, p.117). Esse fato contribuiu para que as experiências de educação em tempo integral fossem entendidas (pelas políticas públicas, gestores educacionais e mesmo professores) como uma educação para os pobres. Essa educação se daria a partir de uma expectativa salvacionista em que a escola seria incumbida de solucionar os problemas sociais decorrentes das condições de vida precárias a que são submetidas às camadas desfavorecidas da população.

Assim, o conceito de educação integral foi pensado, pelos liberais da década de 20 , como a educação para os pobres, espécie de educação compensatória para a regeneração e inserção das crianças e jovens de baixa renda no mundo moderno. A ideia do tempo integral surgiu com o CECR, e, posteriormente, com os CIEPS, modelos de educação que inspiraram outras experiências de educação integral e em tempo integral em todo Brasil. Partiram do ideal de uma educação para a consolidação da democracia e para o encalce da igualdade de oportunidades, mas que supervalorizaram o papel da escola e de suas funções em uma sociedade 
desigual. O tempo integral, então, seria uma perspectiva salvadora que resolveria todos os problemas sociais, sem questionar os reais fatores da desigualdade advindos de uma sociedade capitalista dividida em classes. Contudo, as experiências trouxeram tentativas de uma escola mais justa, mais bonita, mais bem equipada e que repensou as práticas pedagógicas, o currículo, e a organização da escola e, portanto, abriu caminho para pensar e questionar qual o tempo de escolarização adequado para uma educação integral - no sentido real de integralidade do ser e questionar, também, qual a escola que queremos. Foram, pois, contribuições significativas.

Nas últimas décadas, dentre os vários discursos em disputa, o neoliberal ganhou terreno e cristalizou-se como uma espécie de senso comum para o alcance da qualidade da educação nos veículos midiáticos e mesmo em alguns debates acadêmicos. Essas ideias foram o escopo das políticas públicas em educação realizadas nas últimas décadas no Brasil. 


\section{A EDUCAÇÃO E SEUS REFORMADORES: A ERA DO NEOLIBERALISMO E SEUS DESDOBRAMENTOS PARA A EDUCAÇÃO}

O projeto de educação dos chamados reformadores neoliberais tem influenciado as políticas públicas em educação no Brasil e no mundo. Grupos constituídos por instituições financeiras internacionais e empresariado trazem recomendações para a educação aliadas a um viés econômico, no qual, em seus discursos, a educação é uma das peças centrais para o desenvolvimento e sucesso dos países perante nova estruturação do capitalismo e suas demandas. Mediante as transformações sociais, políticas, econômicas e culturais da sociedade contemporânea, as concepções dos reformadores tornam-se com maior frequência onipresentes em programas e projetos na área educacional.

A partir da década de setenta, com a crise do modelo de acumulação fordista/ taylorista, assistimos a um programa de reformas estruturais que tiveram como intuito aumentar as taxas de lucratividade dos capitalistas. A desregulamentação dos mercados, a diminuição da intervenção dos Estados (como provedores de serviços públicos essenciais) desmobilizaram os projetos de autonomia e bem-estar social ancorados no modelo keynesiano de Estado. O projeto neoliberalista expandiu-se progressivamente para os países da América Latina e cristalizou-se nos anos oitenta, a partir dos programas de ajuste econômico da chamada crise da dívida. Organismos Financeiros Internacionais passaram a atuar mais diretamente nas economias Latino Americanas propondo medidas para superar o déficit público e estabilizar as convulsionadas economias. Nesse contexto, para os reformadores neoliberais, a educação é ferramenta estratégica para a formação de um novo trabalhador ajustado ao novo modelo de divisão do trabalho e capaz perante a reorganização das forças produtivas.

Nesta parte do trabalho, procuramos contextualizar o advento do neoliberalismo na economia mundial e sua repercussão nas políticas públicas em educação. Esse contexto é marcado pela inserção de recomendações de organismos internacionais nos assuntos educacionais na maioria dos países da América Latina e pela participação, cada vez mais ativa, do empresariado em âmbito local. Nosso intuito é refletir sobre as propostas dos reformadores e suas consequências para as políticas em educação, em especial para a educação em tempo integral. 


\subsection{A reorganização do capitalismo}

A reorganização do capitalismo mundial, mediante o discurso do neoliberalismo, modificou profundamente a relação entre os mercados e as economias dos países do globo. Uma nova ordem econômica instaurou-se, baseada na crença, cada vez maior, da eficiência dos mercados e da incapacidade do Estado em gerenciar sua estrutura. O neoliberalismo expressa uma saída política, econômica, jurídica e cultural para a crise hegemônica que assola a economia do mundo capitalista como produto do esgotamento do regime de acumulação fordista, iniciado a partir dos anos 60 e começo dos anos 70 (GENTILI, 2001).

Pablo Gentili (2002) aponta que, para entender o neoliberalismo em termos analíticos, é importante o reconhecimento da noção de crise, característica inerente ao modelo capitalista. O capitalismo atravessa, ao longo da história, uma série de processos de mudanças e rupturas. São processos cíclicos e envolvem todas as esferas da prática social. A crise, ao mesmo tempo em que expressa a necessidade de resolver as contradições inerentes ao seu modelo de sociedade, constitui-se de novas contradições que definirão a nova sociedade que se instaura. Segundo o autor, "Tal processo não questiona a natureza e o caráter do modo de produção, mas sim, imprime a este último, uma renovada morfologia [...] que se reproduzirá até o surgimento de uma nova crise" (GENTILI, 2002, p.231-232).

O neoliberalismo de mercado surge como solução para a crise mundial da década de 70 e alcança seu ponto culminante nos governos de Ronald Reagen (EUA) e Margaret Thatcher (Inglaterra). Partindo da lógica da ineficiência do Estado, prega uma economia de mercado autorregulável, baseada na livre concorrência e no fortalecimento da iniciativa privada. Ao Estado caberia um novo papel, com três funções: policiamento, justiça e defesa nacional. A desregulamentação e a privatização dos serviços públicos seriam pontos fundamentais para a competitividade entre os setores privados, o que traria maior qualidade nos produtos e serviços oferecidos.

Segundo o argumento neoliberal, o Estado interventor, provedor de políticas públicas orientadas para a universalização de diretos, gera improdutividade e ineficiência, pois produz um funcionamento ineficiente do mercado, o que cria novas desigualdades ao impedir a livre concorrência. O Estado de Bem-Estar Social teria uma essência totalitária, pois obstruiria um elemento da natureza humana, o direito de escolha. Essas são a justificativas centrais para a redução da intervenção Estatal e para as privatizações dos serviços públicos e das políticas sociais (GENTILI, 2002). 
O início da década de 70 foi marcado pela abertura dos países ao capital especulativo no intuito de atrair os excedentes mundiais. Esse fato resultou no enfraquecimento das políticas de proteção social que marcaram as décadas anteriores. Houve então uma redução de gastos estatais e um incentivo da arrecadação de recursos para remunerar o capital especulativo. Assim, o Estado de Bem-Estar Social dos países desenvolvidos começa um processo de desmoronamento em nome da globalização ${ }^{14}$ e do livre mercado, conforme defende Singer:

No primeiro Mundo, a globalização inverteu o sentido da evolução: o desemprego é alto e persistente, a renda se concentra, a pobreza volta a crescer depois de ter quase desaparecido, a exclusão social torna-se cada vez maior, trazendo em sua esteira a xenofobia, o racismo, e o neofascismo. O Estado de Bem-Estar Social vai sendo corroído, através do corte do gasto social do governo, que resulta da redução ampla dos impostos diretos que recaem sobre as camadas privilegiadas. (SINGER, 1996, apud FRIGOTTO, 2000, p.43).

Ocorreu um esgotamento do modelo fordista que se caracterizava pelas elevadas taxas de acumulação, pela busca do pleno emprego e por ganhos na produtividade e no consumo de massas. Essas ideias estavam firmadas na generalização da industrialização e na visão de um desenvolvimento harmônico, progressivo e ilimitado (FRIGOTTO, 2001). Todavia, as expectativas no modelo fordista sob um Estado regulador foram abaladas por três processos econômicos associados: estagnação, desemprego e inflação acelerada (GENTILI, 2001).

Nos anos 80, com a queda da inflação e a recuperação das taxas de crescimento da economia dos países desenvolvidos, foi provado que "a economia podia crescer e o desemprego podia aumentar sem que uma coisa impedisse a outra" (GENTILI, 2001, p.78). As crenças na possibilidade de distribuir os frutos do crescimento do capitalismo foram abaladas e não tardou a aceitar que "uma certa dose de desemprego podia constituir um bom estímulo competitivo às meritocráticas economias na era da globalização (GENTILI, 2001, p.88).

A reestruturação do modo de produção capitalista teve como propósito encontrar uma maneira de retomar suas taxas de lucratividade. Tal situação implicou em mudanças nas formas de organização do trabalho, no formato de organização das empresas e na forma de contratação dos trabalhadores. Esse processo, conhecido como acumulação flexível do capital, caracterizase pela flexibilidade dos processos de trabalho e dos mercados de produto e de consumo.

\footnotetext{
${ }^{14}$ Globalização é "uma gama de fatores econômicos, sociais, políticos e culturais que expressam o espírito político da época e a etapa de desenvolvimento do capitalismo em que o mundo se encontra atualmente" (Libâneo et all, 2015 , p.61). No conceito, esconde-se a ideologia neoliberal por meio da ideia de que basta liberalizar a economia e suprimir as formas superadas de intervenção social para culminar no alcance de um sistema mundial autorregulado (Touraine, apud Libâneo et all, 2015).
} 
Evidencia-se, nesse processo, a dispersão da produção e do trabalho, ao mesmo tempo em que se verifica a desregulamentação e a monopolização da produção (LIBÂNEO et all, 2015).

Os avanços técnico-científicos da chamada terceira revolução industrial, da era digital, da sociedade do conhecimento ou da revolução tecnológica levam à crença da necessidade de qualificação profissional para a superação das contradições instaladas com o reordenamento das forças produtivas. A ciência e a técnica fazem crescer a produção e diminuir o trabalho humano, daí a necessidade de formação do trabalhador mediante as transformações em vigor. Para Libâneo et all (2015, p.70), essa visão enquadra-se em um determinismo tecnológico que não corresponde ao real, pois "é preciso considerar que as transformações técnico-científicas resultam da ação humana concreta, ou seja, de interesses econômicos conflitantes que se manifestam no Estado e no mercado".

As consequências principais desse processo são: a destruição de postos de trabalho (decorrente do desemprego estrutural) e a precarização (flexibilização) do trabalho, mediante a retirada dos direitos trabalhistas conquistados pela classe trabalhadora. Esse processo ocorre “pela conjugação da globalização excludente, que amplia o desenvolvimento desigual, e pelo monopólio privado da ciência e tecnologia. (FRIGOTTO, 2001, p.41). A base tecnológica flexível permite um deslocamento dos investimentos produtivos de uma parte do mundo para outra e faz com que se consolide a hegemonia do capital financeiro, que "circula, como uma nuvem, de um polo a outro do planeta, facilitado pelas redes de informações sob a tecnologia da microeletrônica, em busca de valorização (FRIGOTTO, 2001, p.42). Com isso, as organizações sindicais são enfraquecidas e são obrigadas a negociar os direitos conquistados por uma possibilidade de emprego.

A abertura econômica e a crescente limitação do poder do Estado levaram à extensão e à ampliação da autonomia do mercado mundial, à interdependência econômica e ao aumento do poder transnacional. De um lado, o poder está concentrado nas forças de mercado, ou seja, nas mãos de grandes grupos financeiros que, em combinação com o Estado, definem as estratégias de desenvolvimento e os ajustes político-financeiros. Do outro lado, o poder de decisão ocorre em âmbito internacional por meio de organismos internacionais, com grande concentração de poder econômico e militar ${ }^{15}$ (LIBÂNEO et all, 2015).

Esta nova ordem constitui uma sociedade violenta, na qual a exclusão social e as diferentes formas da barbárie são processos naturalizados. A pobreza, a má distribuição de renda,

\footnotetext{
15 Organização da Nações Unidas (ONU), Organização do Tratado do Atlântico Norte (OTAN), O Fundo Monetário Internacional (FMI), O Banco Mundial (BIRD), O Acordo Geral de Tarifas e Comércio (Gatt), A Organização de Cooperação e Desenvolvimento (OCDE), A organização Mundial do Comércio (OMC).
} 
o desemprego estrutural e até o extermínio de populações inteiras ${ }^{16}$ são justificativas para a boa saúde dos mercados e para o bom andamento do capitalismo financeiro.

Segundo François Dardot e Christian Laval, o neoliberalismo diferencia-se do liberalismo pelo "reengajamento do Estado" que se consiste em uma nova lógica normativa capaz de reorientar políticas e comportamentos. Assim, a ideia do laissez-faire e de um Estado ausente e fraco é errônea no neoliberalismo. O Estado deve ser forte para garantir que as regras do livre mercado e da concorrência não sejam violadas, o que se resume no jargão "Economia livre, Estado forte". Ao Estado caberia um caráter disciplinar que o torna guardião "das regras jurídicas, monetárias, comportamentais, atribui-lhe a função oficial de vigia das regras da concorrência”. (DARDOT E LAVAL, 2016, p.191). Logo, um Estado muito mais estrategista do que produtor de direitos e de políticas públicas.

Instara-se um governo empresarial, que tem o dever de reformar e administrar a sociedade para coloca-la a serviço das empresas e garantir a competição, onde as decisões macroeconômicas são amplamente o resultado de decisões públicas e privadas (DARDOT E LAVAL, 2016) Segundo os autores, embora os Estados detenham de certa autonomia em suas decisões, por outro lado, são colocados sob pressão por instâncias supragovernamentais e privadas que determinam os objetivos e a maneira de condução da política, logo, "assim como os gerentes das empresas foram postos sob vigilância dos acionistas, os dirigentes dos Estados estão sob vigilância de expertises e das agências de classificação de riscos “ (DARDOT E LAVAL, 2016 p.276). Ainda nesta esteira, apesar de sua vigilância e mecanismos de pressão, o mercado não se opõe de maneira abrupta e coercitiva, mas forjou a percepção por meio das recomendações dos organismos internacionais, de um modelo universalmente aceito para a boa governança rumo ao crescimento econômico.

O ideário neoliberal torna-se senso comum e é relativizado como uma saída para o desenvolvimento dos países não desenvolvidos. A partir dos anos 80 , cristalizou-se uma série de reformas, em quase todos os países da América Latina, em favor de um rigoroso ajuste econômico para superar o déficit público e estabilizar as economias fracas. A partir de um conjunto de propostas, de organismos internacionais como BM e FMI, um receituário é aplicado para enfrentar e superar as crises econômicas. Essas recomendações ficaram conhecidas como o Consenso de Washington.

\footnotetext{
${ }^{16}$ Como no caso em que dirigentes do FMI, face à crise mexicana, afirmavam que o mercado só retornaria a ter confiança para investir no México se o governo exterminasse os rebeldes de Chiapas; ou no caso da justificativa da morte precoce das crianças subnutridas porque há falta de remédios e aparelhos, a atenção deve ser dada às crianças com chances de cura (FRIGOTTO, 2002).
} 
O Consenso de Washington, formulado por John Willianson ${ }^{17}$, inclui dez tipos de reformas, que, na maioria das vezes, foram adotadas pelos governos latino-americanos a partir da década de 80. As reformas são: 1) disciplina fiscal; 2) redefinição das prioridades dos gastos públicos; 3) reforma tributária; 4) liberalização do setor financeiro; 5) manutenção das taxas de câmbio competitivas; 6) liberalização comercial; 7) atração das aplicações de capital estrangeiro; 8) privatização de empresas estatais; 9) desregulação da economia; 10) proteção de direitos autorais (GENTILI, 2002).

Essas orientações sintetizam a hegemonia do capitalismo globalizado por meio da construção de uma política de consentimento. Assim, os organismos internacionais financeiros extrapolam suas funções de simples agências de crédito e, na verdade, exercem uma função político-estratégica fundamental nos processos de ajuste e restruturação neoliberal. Eles constituem-se, para Gentili, em uma "poderosa e pouco dissimulada ferramenta de pressão a serviço da política exterior norte-americana" (GENTILI, 2002, p.29). Os organismos internacionais são fundamentais na inserção e introdução dos programas de ajuste-estrutural, exercendo forte caráter tutelar sob as economias latino-americanas.

As agências financeiras internacionais orientam políticas governamentais para a integração dos países não desenvolvidos na nova ordem de mercado. "Dissemina-se o discurso da integração dos países subdesenvolvidos à economia mundial, como forma de tornarem-se desenvolvidos e serem salvos do futuro catastrófico não demarcado pelos estágios do capitalismo avançado" (LIBÂNEO et all, 2015, p.113).

Neste contexto, a educação tem um papel estratégico perante a reorganização das forças produtivas e da nova divisão do trabalho, o que faz com que esteja na pauta de agentes econômicos. Os organismos financeiros internacionais exercem grande influência nas políticas de educação por meio de assessorias diversas ou/e financiamentos. Essa influência, todavia, não ocorre de maneira espontânea, pois os organismos financeiros estão inseridos em um jogo de tensões do qual participam outros atores sociais, como o Estado e as reivindicações da população e da classe trabalhadora.

O BM assumiu um papel de destaque, exportando pacotes de políticas em educação a partir de um diagnóstico comum acerca da crise educacional e de suas saídas nos países não desenvolvidos. Suas recomendações orientaram as reformas educativas em todo mundo e o Brasil não foi exceção. Segundo Torres (2001), o BM transformou-se na principal agência técnica em matéria de educação para os países em desenvolvimento.

\footnotetext{
17 John Willianson é economista. Foi conselheiro do FMI entre 1972-1974 e economista-chefe do Banco Mundial para o Sul da Ásia entre 1996-1999.
} 


\subsection{Os organismos internacionais e a educação: um projeto para as competências e para a "solução" da pobreza}

Com um discurso de combate à pobreza para a inserção dos países periféricos ao mercado global, o BM financiou uma série de projetos nas áreas sociais e assistenciais. O banco incorpora um discurso de sustentabilidade, justiça e igualdade social, no qual a escolarização, em seus documentos, é fator central para a redução da pobreza e para a diminuição das disparidades sociais.

No que tange à educação, até meados da década de 90, o discurso central do BM era o investimento como forma de potencializar o capital humano. A formação deveria basear-se na produtividade, na competitividade, na qualidade total, na eficiência e na eficácia. Os pobres seriam recursos produtivos que careceriam de investimentos e, portanto, a solução para a pobreza estaria na educação voltada à aquisição da qualificação do trabalhador. A partir de 90, as teorias do capital humano são reestruturadas e surgem as pedagogias das competências, que colocam à escola a missão de desenvolver, não mais a qualificação, mais as competências necessárias para a empregabilidade. Também na mesma década, o discurso da escolarização como combate à pobreza e a miséria, no objetivo de inserção dos pobres na economia de mercado, se tornou a cartilha dos documentos do Banco Mundial para a educação.

O BM surgiu em 1944, na Conferência de Bretton Woods, com a finalidade de conceder empréstimos com juros baixos para os países destruídos pela II Guerra Mundial. A Partir de 1950, com a Guerra Fria, criou-se uma série de programas de empréstimos e assistência técnica para a incorporação dos países não desenvolvidos ao bloco capitalista. Até a década de 70, 70\% dos programas de empréstimo era voltado para políticas de industrialização, visando a incorporação desses países ao comércio global. A partir dos anos 80, o BM acentua em seu discurso a preocupação com a pobreza e amplia seus investimentos nas áreas relacionadas aos setores sociais (moradia, alimentação, água, saúde e educação) (HADDAD et all, 2008).

A relação direta entre educação e nível de desenvolvimento econômico foi discurso recorrente das agências internacionais nos anos 70 e 80. Para a teoria do capital humano, ocorre o desenvolvimento linear e espontâneo entre instrução e nível de desenvolvimento econômico. A noção do capital humano vem responder à questão da causa das desigualdades entre as nações e entre os indivíduos dentro da mesma sociedade. Nessa perspectiva, a resposta está na diferença de investimento no trabalhador, isto é, no investimento em escolaridade e treinamento. Do ponto de vista da formação, a questão que se coloca é: quais “conhecimentos, 
atitudes e valores a serem desenvolvidos na escola e na educação profissional que são funcionais ao mundo do trabalho?" (FINKEL, 1977 apud FRIGOTTO, 2005 p.6).

Para Gaudêncio Frigotto, a noção de desenvolvimento como sinônimo de crescimento econômico, dentro de uma perspectiva linear, não leva em consideração as relações de poder que permeiam a sociedade. Assim, a ideia veiculada de que "os grupos socialmente excluídos, pobres de baixa renda estão nesta situação porque têm baixa escolaridade e educação profissional, não só é falsa como inversa" (FRIGOTTO, 2005. p.1). O autor aponta que a pobreza está vinculada "aos processos históricos de colonização e de reiterada subordinação aos centros hegemônicos do capitalismo que até hoje impedem que se desenvolvam autonomamente" (FRIGOTTO, 2005. p.1).

Nos anos 90, com a acentuação do desemprego estrutural, as teorias do capital humano adquirem novas fundamentações. Como a garantia de empregabilidade não é certa, caberia à escola ensinar e, ao indivíduo, buscar as competências requeridas pelo mercado. A educação estaria voltada para o (dese)emprego, como aponta Gentili (2005). O termo "competência", derivado da noção de capital humano, surge nos meios empresariais e é incorporado à educação para inseri-la aos desafios do mercado de trabalho (FRIGOTTO, 2005). Portanto, a partir da noção de competências para a empregabilidade, a função da escola estaria imbricada à lógica do capital estrangeiro e das grandes corporações. Seria papel das instituições escolares desenvolverem habilidades para a inserção no mercado de trabalho, sem a promessa de garantia efetiva de emprego. Assim, em meio às incertezas sobre a garantia de emprego, o próprio indivíduo é responsabilizado pela aquisição das competências que o levariam ao sucesso.

Desta maneira, como aponta Bourdieu, a escola passa a ser um fator extremamente competente na manutenção da ordem social, pois fornece legitimidade às desigualdades na medida em que cria uma diversificação "oficial ou oficiosa", dentro dos variados percursos escolares nos sistemas de ensino. A partir de então, a educação é enxergada como um capital a ser investido, de maneira certa, na hora certa “[...] os alunos "bem nascidos" que receberam da família um senso perspicaz do investimento, assim como os exemplos ou conselhos de amparálo em caso de incerteza, estão em condições de aplicar seus investimentos no bom momento e no lugar certo" (BOURDIEU, 2002, p.223). Cria-se uma clivagem dentro dos sistemas escolares onde, depois de anos de escolarização, os alunos das classes favorecidas recebem uma formação apropriada para galgar os postos de alta especialização, enquanto os pobres chegam ao fim do ciclo com um diploma desvalorizado.

Para Frigotto et all, a teoria da pedagogia das competências estabelece o reaparecimento da teoria do capital humano com uma roupagem atual, sua função é "tentar explicar o 
agravamento das desigualdades no capitalismo contemporâneo. Assim, fica mais fácil atribuir ao indivíduo a responsabilidade por suas desgraças e por sua derrota. Sou pobre porque sou incompetente e sem qualificação" (BELLUZZO, 2001 apud FRIGOTTO et all, 2005, p.10). Caberia, então, às escolas, ensinar as "competências" necessárias ao sucesso, baseadas na competitividade, no individualismo e na flexibilização, isto é, ensinar habilidades que produzam um trabalhador que seja capaz de atender às demandas das empresas e não da sociedade.

Na visão de Laval, as teorias do capital humano e das competências dão justificativa econômica para os gastos em educação, "a única que tem valor hoje em dia aos olhos dos que tem poder" (LAVAL, 2004 p. 26). O autor afirma que, na visão dos reformadores, para se justificar o investimento em educação, a escola deve se concentrar em ensinar saberes úteis correspondentes as necessidades das empresas. Em sua ótica, há um apelo a favor do investimento educativo para as competências necessárias ao emprego, e por outro lado, uma campanha para a redução dos conhecimentos julgados inúteis, isto é, sem conexão com a empregabilidade (LAVAL, 2004).

James Guthrie, um especialista da OCDE, ilustra bem a ideia da formação escolar para as competências com vistas ao desenvolvimento econômico.

"Antigamente, um país devia sua influência em grande parte às riquezas que
ele podia extrair do solo mas, em nossos dias, seu poderio é, cada vez mais,
subordinado às riquezas do espírito [...] Considera-se cada vez mais, a
inteligência humana- quando é desenvolvida pela educação e se alia a
competências muito especializadas- como recurso econômico primordial de
uma nação, do qual esta última tem maciçamente necessidade. (LAVAL, apud
OCDE, 2004 p.24).

De acordo com Laval, a competência não é validada por um título e substituí a noção de qualificação. A qualificação por meio de um diploma dá um conjunto de garantias e direitos relacionados a uma determinada categoria profissional, como o piso salarial. A competência estritamente ligada à eficácia e a flexibilidade justifica uma avaliação permanente por parte do empregador a partir de critérios subjetivos estabelecidos pela própria empresa, portanto, os resultados são compreendidos como uma característica individual do trabalhador e não de sua categoria profissional. Citando o autor, a competência como "Qualidade pessoal reconhecida em um dado momento, ela não suporta nenhum direito, não liga o trabalhador a nenhum grupo, a nenhuma história coletiva” (LAVAL, 2004, p.57). 
Portanto, na concepção de educação para as competências, a escolarização é enxergada como um investimento produtivo de cunho individual e utilitarista. Todo investimento deve ser orientado a garantir ganhos monetários por meio de esforços que miram a taxa de rendimento esperada. Nesta visão, a escola é pensada por uma relação contratual e mercantil com seus clientes usuários onde o sucesso ou fracasso é consequência unicamente do mérito individual.

Segundo Olinda Evangelista e Eneida Shiroma, na década de 90 ganha força, nos documentos internacionais, a escolarização como ponto chave de combate à pobreza. Essa noção está ligada à aquisição de capital social e de educação para assistência e inclusão dos empobrecidos. Temas como justiça, equidade e inclusão aparecem constantemente nos relatórios do BM (os quais deveriam figurar nas políticas educativas para países emergentes) em torno do mote "educação para alívio da pobreza" (EVANGELISTA E SHIROMA, 2006).

O informe do BM dos anos 90 alerta que, para o uso produtivo do recurso mais abundante nos pobres - sua força de trabalho - seria necessário prover-lhes serviços básicos. $\mathrm{O}$ uso da mão de obra aliada à ampliação dos serviços sociais seria condição necessária para a inserção dos pobres na economia globalizada.

Geralmente, porém, os pobres não têm acesso aos serviços sociais básicos: investe-se muito pouco nesse capital humano. Aumentaram assim as chances de que os adultos e crianças pobres permaneçam na condição de pobreza. Para romper o círculo vicioso, os governos deviam encarar como prioridade [...] o atendimento aos pobres. O principal bem dos pobres é o tempo para trabalhar. A educação aumenta a produtividade deste bem. O resultado, no nível individual, é uma renda mais alta. (BANCO MUNDIAL, 1990, p.85).

A partir dos anos 2000, os documentos do BM trazem uma nova conceituação para a superação da pobreza. Além de integração dos pobres como força de trabalho, surgem as ideias de "oportunidade", "autonomia" e "segurança". Portanto, a pobreza passa a ser enxergada não apenas do ponto de vista econômico, mas também social e cultural, na perspectiva de carência. Nessa visão, como aponta Evangelista e Shiroma (2004, p.8), para o BM, "pobre é aquele que não tem, ou tem poucas “oportunidades" econômicas; que não tem, ou tem pouca autonomia no que tange ao seu poder de pressão sobre o Estado e no que tange as barreiras sociais derivadas de sua condição de sexo, etnia raça e status social”. Dessa forma, na visão do BM:

A estratégia apresentada neste relatório reconhece que a pobreza é mais que renda ou desenvolvimento humano inadequado; é também vulnerabilidade e falta de voz, poder e representação. Esta visão multidimensional da pobreza aumenta a complexidade das estratégias de redução da pobreza, porque é preciso levar em conta outros aspectos, como os fatores sociais e as forças culturais. (BANCO MUNDIAL, 2000, p.12). 
No relatório, é apontada a necessidade de repensar as políticas sociais voltadas aos pobres para além da intervenção estatal, envolvendo outros setores sociais, como a sociedade civil e a iniciativa privada, a fim de garantir "oportunidade", "autonomia" e "segurança". "E, dadas as suas importantes complementaridades mútuas, uma estratégia efetiva de redução da pobreza exigirá que o governo, a sociedade civil, o setor privado e os próprios pobres empreendam ações nessas três frentes" (BANCO MUNDIAL, 2000, p.33).

Em 2013, em seu relatório anual, o BM, propõe metas pontuais de combate à pobreza extrema até 2030, através de um ponto de vista sustentável do ponto vista ambiental, social e econômico. "Erradicar efetivamente a pobreza extrema reduzindo para 3\% até 2030 a parcela da população que vive com menos de US\$ 1,25 por dia e promover a prosperidade compartilhada por meio do aumento da renda dos $40 \%$ mais pobres da população de todos os países em desenvolvimento". (BANCO MUNDIAL, 2013 p.2). Segundo o BM, para alcançar os objetivos estipulados faz-se necessário investimentos em áreas prioritárias: Melhorias em energia, meio ambiente, infraestrutura, saúde e educação. Nota-se, que a preocupação passa da pobreza para a pobreza extrema, ou seja, os mais pobres, dentro dos pobres.

No que tange propriamente aos aspectos pedagógicos, $\mathrm{O}$ BM tem um projeto que abrange um amplo campo, desde a macro política até a sala de aula. $\mathrm{O}$ receituário educacional propagado pelo BM alastrou-se por meio das reformas educacionais, ocorridas em todo o mundo, por meio de financiamentos diretos e/ou assessorias. Duas tendências norteiam as políticas de concessão de créditos e assessoria: a primeira é a vinculação à política econômica estritamente relacionada ao capital financeiro; a segunda é a escolaridade como alívio da pobreza.

Durante as últimas décadas, o BM vem sugerindo metas educacionais com os seguintes termos: a) Prioridade na educação primária; b) Melhoria na eficácia da educação primária; c) Ênfase nos aspectos administrativos; d) Descentralização e autonomia das instituições escolares, entendida como transferência de responsabilidade de gestão e de captação de financiamento (nessa perspectiva, ao Estado caberia manter centralizadas as funções de fixar padrões, facilitar os insumos que influenciam o rendimento escolar, adotar estratégias flexíveis para a aquisição e usos de tais insumos e monitorar o desempenho escolar); e) Análise econômica como critério dominante na definição de estratégias (ALTMANN, 2002, p.80).

No relatório do BM, "prioridades y estratégias para la educación", as prioridades da educação nos países não desenvolvidos foram elencadas de modo a: a) eliminar o analfabetismo e melhorar o desempenho escolar por meio de reforma do financiamento e da administração da educação, começando pela função do governo e pela busca de novas fontes de recursos; b) 
estreitar os laços da educação com o setor privado; c) atentar aos resultados; d) avaliar a aprendizagem e) descentralizar as políticas sociais (BANCO MUNDIAL, 1995). Sendo assim, o BM vem insistindo em um enfoque na educação primária, enquanto os investimentos nas demais modalidades de ensino devem ser repassados para a iniciativa privada. Outra recomendação do Banco é a criação de mecanismos de avaliação externa para a adoção de um currículo único e um maior controle de dados. Segundo Rosa Maria Torres (1995), desde a década de 90, o fato de melhorar a qualidade do ensino está intrinsicamente ligado à melhoria nos resultados do rendimento escolar, verificados por avaliações em larga escala.

$\mathrm{O}$ documento expressa que o objetivo fundamental do BM consiste em orientar a realização de um pacote de educação que tem, por finalidade, reduzir a pobreza e melhorar o nível de vida por meio do desenvolvimento sustentável e do investimento nos seres humanos (BANCO MUNDIAL, 1995). Esse dado nos impulsiona a afirmar que, no discurso do BM, a educação tem o papel de trazer a ascensão social das camadas mais vulneráveis da sociedade. Todavia, esse propósito deve ser desenvolvido com eficiência no gerenciamento dos custos, o que é extremamente contraditório, como aponta José Luiz Coraggio: “O Banco Mundial propõe aliviar a pobreza por meio de medidas que, se forem implementadas, contradizem seu objetivo de minimizar o gasto público" (CORAGGIO, 1995, p.77). Ao avaliar as políticas dos organismos internacionais para a escola, Laval argumenta na mesma lógica e aponta: "querer fazer da escola uma organização eficaz a serviço da economia supõe que se aceite a necessidade e importância dos investimentos educativos e que não se confunda com despesas improdutivas." (LAVAL, 2004 p. 289).

O Banco Mundial também recomenda a descentralização no intuito de envolver a comunidade e obter melhores resultados. Ele propõe que a administração dos recursos seja feita, o mais diretamente possível, pelas instituições escolares e que sua arrecadação também seja responsabilidade das comunidades envolvidas. Laval (2004) aponta que nem toda descentralização segue em direção ao mercado, mas que tudo depende do seu real intuito e das regras que lhe são fixadas, que podem ser, desde um maior controle democrático das decisões pela comunidade escolar, até o não comprometimento do Estado com as questões organizacionais e financeiras da escola transferindo para a sociedade a responsabilidade dos resultados obtidos. Nesta última acepção, na visão de Sergio Haddad, é tendência mundial convocar as comunidades para a participação nos assuntos escolares para se responsabilizarem por funções que deveriam ser propriamente estatais, repassando as obrigações do Estado para terceiros. Essa visão "coloca em risco a noção de Educação como direito a ser garantido por políticas públicas" (HADDAD et all, 2008, p.26). 
Para Sonia Kruppa (2001), a influência exercida pelo BM na educação passa de projetos pontuais, nos 50 e 70, para uma visão "sistêmica" e "abrangente". O Banco oferece vantagens coorporativas para a consolidação do ordenamento sistêmico (recursos, conhecimentos, assessorias), propondo inclusive adequações jurídicas para a concretização de suas propostas. A descentralização das políticas ocorre pela centralização do controle, por meio da padronização dos currículos e a criação de um sistema externo de avaliação. Outro enfoque apontado é a aliança dos interesses privados na esfera pública, em que o banco tem um papel decisivo na privatização de políticas sociais e de espaços públicos.

O BM se apresenta como o "Banco do Conhecimento" a partir de uma arquitetura organizacional "achatada" e "tentacular" na qual sua organização em rede atinge várias ações em vários lugares ao mesmo tempo (KRUPPA, 2001). A partir das proposições de um grupo de especialistas e de um planejamento flexível, as políticas para a educação do BM são legitimadas e tornam-se sinônimo de práticas eficazes.

Em síntese, para o BM, a educação é a solução para prevenir problemas da expansão capitalista mediante a pobreza e a marginalidade. Daí advém o fato de que a aprendizagem e a escola se prestam, em primeira instância, à solução de problemas sociais e econômicos dentro dos critérios do mercado global. A população pobre é vista como insumo que deve ser inserida na lógica mercantil a fim de atenuar os conflitos e anestesiar as desigualdades. $\mathrm{Na}$ visão de Marília Fonseca, a educação, com intuito único de redução da pobreza, faz dela "medida compensatória para proteger os pobres e aliviar as tensões sociais, medida para a contenção demográfica e aumento da produtividade.” (FONSECA 2001. p.91).

Segundo Torres (1995), as propostas do BM para a educação são feitas basicamente por economistas, enquanto as propostas pedagógicas especializadas são formuladas pela UNESCO. As propostas pedagógicas disseminadas pelos organismos internacionais são nosso próximo tópico.

\subsection{As pedagogias do aprender a aprender e da educação ao longo da vida para a formação do neossujeito}

A ação direta dos organismos financeiros internacionais na educação dos países da América Latina ocorre a partir da Conferência Mundial sobre Educação para Todos, realizada na Tailândia em 1990, que reuniu delegados de 150 países incluindo especialistas em educação e autoridades nacionais. O evento foi patrocinado pelo BM, PNUD, UNESCO e UNICEF e produziu o documento "Declaração Mundial sobre Educação para Todos". Os governos 
presentes assinaram a declaração e designaram um marco de ação, além de comprometerem-se a garantir uma educação básica de qualidade para as crianças de seus respectivos países (TORRES, 2001).

A declaração define estratégias gerais para o desenvolvimento de uma educação para todos, sendo elas: a) satisfazer as necessidades básicas de aprendizagem para todos; b) universalizar o acesso à educação e promover a equidade; c) concentrar a atenção na aprendizagem; ampliar os meios e o raio de ação da educação básica; d) propiciar um ambiente adequado à aprendizagem; e) fortalecer alianças com a sociedade (UNESCO, 1990).

A Declaração Mundial de Educação para Todos, em seu preâmbulo faz alusão a Declaração Universal dos Direitos Humanos, afirma que a educação é direito de todos, além de enumerar uma série de ações a serem realizadas para o acesso e melhoria da educação em todo mundo. Para a Declaração, problemas como: aumento da dívida dos países que os levam a beira da estagnação econômica; aumento da população; diferenças econômicas entre as nações; a guerra e as lutas civis; a degradação do meio ambiente são fatores que impedem a escolarização de crianças e adolescentes pelo mundo.

O documento disseminou uma visão de educação que foi adotada nas políticas públicas dos países de todo o mundo, em especial dos da América Latina. Constituiu-se como uma espécie de plano universal que traria um receituário efetivo para a melhoria da qualidade da educação e, consequentemente, promoveria avanços econômicos e sociais. Da publicação, destacamos alguns aspectos: a importância de pesados investimentos no ensino básico; a convocação de toda sociedade para tomar responsabilidade sobre a escolarização e a substituição da igualdade pela equidade (UNESCO, 1990).

A preocupação com a universalização do ensino fundamental é uma demanda legítima tanto da população quanto de educadores e de movimentos organizados. Todavia, o relatório de Jontiem trouxe consigo subsídios para a difusão de um entendimento, pautado pelos organismos internacionais, de que a escolarização dos segmentos mais pobres da população tem caráter estratégico perante o desenvolvimento e consolidação do capitalismo atual. $\mathrm{O}$ acesso de amplos setores da sociedade à educação é entendido como fator de investimento social e econômico a partir da capacitação para o trabalho e para a entrada no mercado. Esta seria uma estratégia para a redução da pobreza e inserção dos países periféricos na economia de mercado.

Em Jontiem, a responsabilidade pela educação é transferida do Estado para ser incumbência das famílias, do Estado e da iniciativa privada. "Todos os membros da sociedade têm uma contribuição a dar, lembrando sempre que o tempo, a energia e os recursos dirigidos à educação básica constituem, certamente, o investimento mais importante que se pode fazer 
no povo e no futuro de um país" (UNESCO, 1990). Este ponto levou ao entendimento que, nas políticas públicas em educação, caberia às ONGS, a inciativa privada e, à sociedade civil, a reponsabilidade pelo financiamento, pela gestão, e até pelo desenho de políticas públicas implementadas na escola. $\mathrm{O}$ que pode gerar interpretações nas quais o Estado é desresponsabilizado e posto como ineficiente na garantira da qualidade da educação.

O termo equidade, utilizado no relatório, está em substituição ao de igualdade. O termo equidade aparece em muitos textos de políticas públicas e parte do pressuposto de focalizar determinadas políticas sociais nos grupos vulneráveis, supõe assim medidas compensatórias e corretivas que trariam igualdade de oportunidades. Trata-se de assumir as particularidades de cada um e prover um tratamento desigual aos desiguais, em respeito às suas especificidades. Todavia, a equidade, no contexto das sociedades capitalistas, leva à perpetuação da desigualdade, pois não tem o intuito de promover a justiça social, mas tenciona trazer alívio à pobreza e às tensões sociais. "Na área da educação, em que pese a retórica igualitária de “educação para todos", a equidade é restritiva para os pobres, podendo ser resumida na fórmula “o mais para alguns, o menos para todos" (FONSECA, 1998, p.64). Assim, a igualdade de acesso à educação partiria do pressuposto do acesso igual, de todas as esferas sociais, a todos os níveis de ensino. Todavia, o termo equidade, nesse contexto, garante a educação apenas para um grupo focalizado. Àqueles que não têm condições de acesso ao ensino privado, o acesso garantido seria unicamente a educação fundamental. Para Saviani, esse termo "se converteu na categoria central das políticas sociais de um modo geral e, especificamente, da política educacional, sob a hegemonia da orientação política correntemente chamada de neoliberalismo" (SAVIANI, 2000, p.56).

Embora alguns dos tópicos elencados em Jontiem sejam bandeiras para a real qualidade da escola, Libâneo aponta que:

Tão boas intenções são, à primeira vista, compatíveis com uma desejada visão democrática da escola para todos e até com uma visão renovada das políticas educativas. No entanto, esses conceitos necessitam ser examinados com base nas políticas globais definidas pelos organismos internacionais para os países pobres. (LIBÂNEO, 2012 p.18).

Os organismos internacionais partiram dos referenciais de Jontiem a fim de ter legitimidade ao influenciar mais diretamente as políticas educacionais dos países não desenvolvidos. Segundo Torres, em encontros posteriores, a declaração de Jontiem sofreu adições e revisões pelos organismos internacionais, tendo o documento sofrido reformulações para se enquadrar nos moldes das propostas dessas instituições: a) de educação para todos 
reduziu-se a uma educação dos mais pobres; b) de necessidades básicas transmutou-se em necessidades mínimas; c) da atenção à aprendizagem focou-se na melhoria da avaliação dos resultados do rendimento escolar; d) da melhoria das condições de aprendizagem converteu-se em melhorias das condições internas da instituição escolar (TORRES, 2001).

Após a Conferência de Jomtien, foi organizada pela UNESCO a Comissão Internacional sobre Educação para o Século XXI, tendo o propósito de refletir sobre o educar e o aprender na sociedade atual. O resultado desses encontros foi a publicação do texto "Educação: um tesouro a descobrir". O documento difundiu duas das concepções mais conhecidas dos círculos educacionais de todo o mundo nos dias de hoje: o "aprender a aprender" e a "educação ao longo da vida".

O conceito de educação ao longo de toda a vida aparece, pois, como uma das chaves de acesso ao século XXI. Ultrapassa a distinção tradicional entre educação inicial e educação permanente. Vem dar resposta ao desafio de um mundo em rápida transformação, mas não constitui uma conclusão inovadora, uma vez que já anteriores relatórios sobre educação chamaram a atenção para esta necessidade de um retorno à escola, a fim de se estar preparado para acompanhar a inovação, tanto na vida privada como na vida profissional. É uma exigência que continua válida e que adquiriu, até, mais razão de ser. E só ficará satisfeita quando todos aprendermos a aprender. (UNESCO, 1999, p.19).

No documento, conhecido como relatório Jacques Delors ${ }^{18}$, o "aprender a aprender" não é um processo que termina no período de escolarização tradicional. Pelo contrário, deve ir além, não só em termos qualitativos, mas também em termos quantitativos. É algo que se dá “ao longo de toda a vida". O indivíduo não pode mais permanecer imune e passivo diante das mudanças da sociedade contemporânea, deve buscar constantemente a sua atualização diante dos desafios de uma sociedade cada vez mais marcada pela globalização, internacionalização dos mercados e avanços tecnológicos, isto é, um constante aperfeiçoamento para a esfera da empregabilidade.

O relatório concebe "quatro pilares" para a educação ao longo de toda a vida: aprender a conhecer; aprender a fazer; aprender a ser e aprender a viver juntos.

Aprender a conhecer seria conhecer a cultura geral com a possibilidade de dominar, profundamente, um reduzido número de assuntos; aprender a fazer significaria preparar o indivíduo às inúmeras situações, ou seja, prepará-lo de forma a facilitar o trabalho em equipe e

\footnotetext{
${ }^{18}$ Jacques Delors é um importante político europeu, de origem francesa, ligado a assuntos de ordem econômica e financeira. Trabalhou no Banco da França, foi ministro da Economia e Finanças, presidiu a Comissão Econômica e Monetária e a Comissão Europeia (UNESCO, 1999, p.270).
} 
prepará-lo também de forma a desenvolver competências sociais em paralelo aos estudos; aprender a ser consistiria no desenvolvimento da responsabilidade pessoal para um destino coletivo, no incentivo da necessidade de autoconhecimento a fim de potencializá-lo; aprender a viver juntos significaria incentivar a realização de projetos apaziguadores para os inevitáveis conflitos advindos da globalização e das modificações do cenário internacional (UNESCO, 1998).

Para Duarte (2000), as pedagogias do "aprender a aprender" trazem um esvaziamento da função da escola, que seria, nessa perspectiva, apenas a de promover competências para a adaptação do indivíduo. Significaria, pois, preparar pessoas dispostas a aprender o que quer que seja, desde que esse aprendizado seja utilizado como bem nos mercados da empregabilidade. Segundo Duarte:

O lema aprender a aprender passa a ser revigorado nos meios educacionais, pois preconiza que à escola não caberia a tarefa de transmitir o saber objetivo, mas sim a de preparar os indivíduos para aprenderem aquilo que deles for exigido pelo processo de sua adaptação às alienadas e alienantes relações sociais que presidem o capitalismo contemporâneo. A essência do lema "aprender a aprender" é exatamente o esvaziamento do trabalho educativo escolar, transformando-o num processo sem conteúdo. (DUARTE, 2000 p.9).

Já a noção de "educação ao longo da vida" caracteriza-se pela ideia de que a escola deva ter um papel de formadora inicial, isto é, deve dar subsídios para uma formação contínua e permanente. Para a OCDE “o aprendizado durante a vida deve responder a vários objetivos: favorecer o desabrochar pessoal; enriquecer os lazeres (em particular durante a aposentadoria); reforçar os valores democráticos; encorajar vida coletiva; manter a coesão social e favorecer a inovação, a produção e o crescimento econômico". (OCDE, apud LAVAL, p. 28). Para Laval (2004), apesar da retórica humanista, é preciso questionar qual o real sentido que a expressão "educação ao longo da vida" tem para os organismos internacionais e para as políticas que dela decorrem.

Segundo o autor, a significação é claramente utilitarista, "o essencial repousa na capacidade do trabalhador de continuar, durante toda sua existência, a aprender o que lhe será útil profissionalmente" (LAVAL, 2004, p.49). A escola, então, deve abandonar tudo o que é considerado supérfluo e não produtivo, para ensinar o que realmente importa ao mercado. Portanto, mediante a globalização dos mercados; a produção flexível; a aceleração das transformações técnico-científicas; o desemprego estrutural e a sociedade do conhecimento, o indivíduo deva adquirir uma série de competências que o preparem para os desafios da vida contemporânea. 
Nesta visão, a escola perde espaço para outros espaços da sociedade ditos formadores, pois, não devem existir espaços desconectados do mercado dedicados ao ensino de saberes não utilitários. Portanto, como aponta Laval

\begin{abstract}
Aí está o coração de uma estratégia desreguladora que coloca no mesmo plano, instituições escolares, empresas, aprendizados em domicílio e associações em uma noção genérica que pretende, em nome das necessidades do indivíduo e da lógica da demanda criar um vasto mercado da educação no qual as ofertas e financiamentos seriam, cada vez mais numerosos e diversificados (LAVAL, 2004, p.52).
\end{abstract}

Esse paradigma responsabiliza o cidadão pelo seu dever de aprender, isto é, cabe a cada um assumir as consequências dos percursos formativos que tomará ao longo de sua existência. E ainda, para escolher de forma lúcida o melhor caminho a ser trilhado, não sendo as escolas mais responsáveis pelo processo, mas os especialistas em educação, isto é, organismos internacionais e empresas privadas, que devem ser consultados.

A Declaração de Jomtien inaugurou presença dos organismos internacionais na educação em escala global: Banco Mundial (BM), Fundo Monetário Internacional (FMI), Banco Internacional de Reconstrução e Desenvolvimento (BIRD) e Programa das Nações Unidas para o Desenvolvimento (PNUD). Essas organizações se apropriaram do conteúdo de Jontiem e estabeleceram paradigmas que foram amplamente difundidos como a fórmula de sucesso para a educação dos países em desenvolvimento, trata-se do que Gentili (2002) denominou "o consenso de Washington da Educação". Para essas organizações, a educação é entendida a partir de um paradigma economicista, no qual a escolarização é um investimento gerador de renda tanto para o indivíduo como para a economia do país.

O conceito de "educação ao longo da vida" traz o pressuposto teórico para justificar o aumento do tempo de escolarização, dentro de certa concepção de educação integral, a qual Freitas e Galter definiram como educação integrada ${ }^{19}$. Coadunando com a visão do BM, que, a partir de ações sociais e culturais compensatórias, a permanência escolar para o desenvolvimento de competências seria assegurada, caberia, então, à escola, desenvolver estratégias para garantir a permanência e propiciar aprendizagens para a empregabilidade por meio do aumento da jornada escolar. Esse julgamento está de acordo com o que aponta Libâneo, ao refletir sobre as propostas de educação nos documentos internacionais aponta que:

Neste novo enfoque da educação, onde se verifica forte peso da concepção pragmática da educação, os papeis da escola e do ensino são minimizados, e

\footnotetext{
${ }^{19}$ Conceito ao qual já nos referimos no capítulo anterior.
} 
são destacadas funções voltadas para formar sujeitos produtivos e novos cidadãos que saibam consumir e lidem bem com as tecnologias digitais. Para isso, são introduzidas estratégias para melhorar a qualidade da educação, incluindo ações socioeducativas com seu entorno ambiental imediato para assegurar o êxito escolar. (LIBÂNEO, 2014, p.7).

Assim, a educação passa a ser ferramenta indispensável para a garantia da consolidação das mudanças do capitalismo globalizado. A aquisição de competências por meio de aprendizagens para a prática social e para o mercado de trabalho é o novo desafio posto pelos organismos internacionais às escolas no século XXI. A “educação ao longo da vida” passa a exigir dedicação integral da escola que além de propiciar a aprendizagem, deve assegurar as condições assistenciais para o sucesso de suas ações, a partir da noção redentora de educação como agente central no combate à pobreza e à miséria.

Sandra Sawaya (2012) aponta que, nos documentos internacionais, ocorre uma redefinição do papel da escola na formação dos indivíduos. Há um deslocamento da centralidade do ensino para a aprendizagem que remete a centralidade de um significado comportamental e individual nas propostas de formação. Nesta visão, "Busca-se um cidadão que sabe fazer, agir, ser e conviver em seu entorno social [...] reorientar a formação para a administração de conflitos, de ensinar a não violência na escola gerada pela convivência com diferença de raça, etnia e nacionalidade" (SAWAYA, 2012. p.66). Trata-se, pois, de desenvolvimento centrado na aquisição de habilidades socioemocionais que, apesar da retórica humanista, em uma lógica neoliberal, tem por finalidade trazer o equilíbrio na convivência entre os diferentes, com a finalidade de neutralizar as contradições das desigualdades e injustiças sofridas pelos grupos não dominantes.

Na sociedade capitalista, o trabalho da/na escola possui especificidades que vão em direção contrária ao trabalho alienado e produtor de mais-valia. Marx, quando caracteriza trabalho produtivo e trabalho improdutivo, aponta que só é produtivo o trabalho que produza mais-valia, que sirva para a autovalorização do capital. (MARX, 1978). Assim, o trabalho em uma escola pública não é produtivo, já que não há extração de mais-valia, pois não contribui para a engrenagem do capitalismo. Sendo assim, a escola pode constituir-se de local de resistência pelo caráter específico de seu trabalho, daí as tentativas constates de subordinação da educação à ótica capitalista e as constantes tentativas de aproximação do trabalho exercido pela escola ao trabalho produtivo de uma empresa.

O neoliberalismo não é apenas uma ideologia ou uma política econômica é uma racionalidade, isto é, produz relações sociais, maneiras de enxergar o mundo e se relacionar 
com ele, e novas subjetividades, "o neoliberalismo pode ser definido como o conjunto de discursos, práticas, dispositivos, que determinam um novo modo de governo dos homens segundo o princípio da concorrência" (DARDOT E LAVAL, 2016, p.17). Nesta visão, o neoliberalismo produz uma nova subjetividade onde a concorrência entre os homens é sistematizada e naturalizada, onde cada um deve ser gestor e avaliador de si, onde apenas os melhores triunfam. É o aparecimento do neossujeito.

Em uma sociedade regulada pelos valores de uma empresa se faz necessário reorganizar a subjetividade do indivíduo, ou seja, adaptá-lo a este novo modelo de sociedade. Espera-se um novo cidadão consumidor que se compreenda, não do ponto de vista de coletividade alguma, mas a partir do seu interesse individual em uma constate busca pela liberdade, esta entendida como liberdade para consumir. O novo sujeito do neoliberalismo é enxergado em torno do discurso empresarial.

Este novo cidadão deve ter como valor supremo a competitividade, isto é, um sujeito que se conduza como um ser de competição que assuma os riscos e seja responsável por seus sucessos e fracassos. Logo, são sujeitos empreendedores de si mesmos que farão da competição entre seus semelhantes seu modo vida e sua razão de ser. Tornam-se, portanto, "especialistas em si mesmos" "empregadores de si mesmos" e "inventores de si mesmos" (DARDOT E LAVAL, 2016).

Essa lógica, naturaliza a flexibilização do trabalho e de suas relações, nas quais não há garantia de emprego, a competição é cada vez mais desenfreada e os direitos trabalhistas são reduzidos a nada. Tais mudanças são justificadas pela substituição de um contrato salarial por outra relação entre "empresas de si mesmo", onde:

Todos os domínios da vida individual tornam-se potencialmente recursos indiretos para a empresa, já que são oportunidade para o indivíduo melhorar seu desempenho individual. Portanto, toda a subjetividade, e não apenas o 'homem no trabalho', é evocada para esse modo de gestão, mais ainda na medida em que a empresa seleciona e avalia de acordo com critérios cada vez mais 'pessoais', físicos, estéticos, relacionais e comportamentais. (DARDOT E LAVAL, 2016, p. 346).

Assim, todo indivíduo é proprietário de um "capital humano" que ele precisa acumular a partir de decisões responsáveis, calculadas e esclarecidas que levem em conta os custo e benefícios.

O neossujeito deve estar acostumado a viver na incerteza, qualquer decisão, seja profissional, saúde ou escola, deve ser decidida em âmbito privado e avaliando os riscos, pois 
os homens devem ter liberdade de escolher seus investimentos. Trata-se de uma subjetivação financeira, cujos direitos são transformados em produtos, e todos eles se tornam um objeto financeiro. Daí as justificativas para as privatizações de áreas essenciais, pois não se constituem como direitos adquiridos, mas como produtos disponíveis no mercado de escolha.

O novo homem formado pela lógica neoliberal é estimulado a viver sob a ótica do hedonismo e da produção, "produza-se mais e goze mais". A idealização de ídolos do esporte se torna a personificação do treinamento árduo para a competição, a lógica é estar preparado para qualquer desafio independentemente dos limites físicos e psicológicos "trabalhe mais, alcance as metas a qualquer custo". Também a ideia de uma performance sexual satisfatória a todo momento, para além da idade ou de qualquer circunstância, tem o intuito de vincular sempre alto desempenho ao prazer, o princípio de uma superação contínua e sem limites. A mensagem é que o individuo deve "ser seu próprio trabalhador, seu próprio acionista, ter um desempenho sem limites e gozar sem obstáculos os frutos de sua acumulação, esse é o imaginário da condição neossubjetiva.” (DARDOT E LAVAL, 2016. p.373).

Segundo os autores, sob o peso da competição sem freios e mediante as pressões para produzir e assumir seus próprios riscos os indivíduos são levados a uma série de patologias e diagnósticos clínicos como depressão, ansiedade, solidão, estresse, frustação e desejos suicidas (DARDOT E LAVAL, 20016). A autoestima é a chave para todo o sucesso, e, portanto, todos os problemas psíquicos decorreriam de um domínio insuficiente de si, e da falta de investimento nas competências socioemocionais. Uma lógica de reificação extrema do indivíduo que age como mercadoria a ser lapidada por si mesmo para atender aos desejos do mercado, contudo, mediante sua não adaptação ou enquadramento nada mais o restaria a não ser a descartabilidade.

A escola está diretamente relacionada a formação de novas subjetividades, portanto, sua aproximação e total imersão na lógica do neoliberalismo é vista, pelos reformadores neoliberais, como essencial para a produção de uma nova racionalidade aliada a lógica do capitalismo contemporâneo. Fazer da escola uma empresa é um dos pontos cruciais para o enrijecimento de uma cultura neoliberal pautada na eficácia, na competitividade, no individualismo e no consumismo, e para a formação do neossusjeito, que fará da sua razão de viver o trabalho alienado, portanto, sentirá prazer e satisfação com sua própria exploração.

No Brasil, as orientações dos organismos internacionais para a educação nortearam as políticas públicas a partir da década de noventa. As reformas internacionais colocaram o Brasil em sintonia com as demandas neoliberais e com um modelo constitucional que passou a adotar uma perspectiva educativa segundo seus preceitos. A seguir, descreveremos um pouco a noção 
de políticas públicas e a posição do Brasil mediante as concepções de educação disseminadas pelos organismos internacionais.

\subsection{As políticas públicas e a educação no Brasil a partir da década de 90}

As políticas públicas estão inseridas em determinada concepção de Estado e de política social de modo a constituir a sustentação de suas intervenções. Visões distintas de Estado e sociedade geram diferentes tipos de ações que englobam as decisões tomadas, seu desenho de implementação e suas políticas de avaliação. As políticas públicas se caracterizam pela intervenção do Estado na execução de um projeto de governo. Essa conjuntura é denominada como o "Estado em ação" (HOFLING, 2001).

As políticas públicas são aqui compreendidas como as de responsabilidade
do Estado - quanto à implementação e manutenção a partir de um processo
de tomada de decisões que envolve órgãos públicos e diferentes organismos
e agentes da sociedade relacionados à política implementada. Neste sentido,
políticas públicas não podem ser reduzidas a políticas estatais. (HOFLING,
2001, p.310).

As políticas sociais são caracterizadas pelo modelo de proteção social que o Estado implementa na busca pela diminuição das desigualdades ocasionadas pelo modelo socioeconômico (HOFLING,2001). As políticas sociais, em um Estado capitalista, são marcadas por especificidades que perpassam as contradições inerentes a seu próprio modelo sistêmico. Na visão de Claus Offe, a política social se origina a partir dos problemas específicos do modo de produção capitalista, é a maneira "pela qual o Estado tenta resolver o problema da transformação duradoura de trabalho não assalariado em trabalho assalariado" (OFFE, 1984, p.15).

Assim, as políticas sociais estão inseridas no processo de reorganização da sociedade capitalista na tentativa de equacionar três problemas: convencimento da população em proletarizar-se; construção de condições para que a proletarização ocorra de tal maneira que as parcelas não inseridas no processo produtivo fiquem em controle do Estado; Regulamentação da quantidade de trabalhadores necessários na produção e sua reprodução como força de trabalho (OFFE,1984).

O trabalho é o agente principal na organização da sociedade. Na visão de Marx, os vários modos de produção ao longo da história estão relacionados ao desenvolvimento das forças produtivas e às relações de produção que se estabelecem entre os vários atores da 
sociedade. O sistema capitalista é caracterizado pelo trabalhador assalariado dos que não detém os meios de produção, portanto vende ao capitalista a única mercadoria que dispõe: sua força de trabalho. Nesse processo, as políticas sociais seriam um instrumento de organização de uma sociedade de trabalhadores assalariados para o controle qualitativo do processo de produção.

Nessa mesma perspectiva, a origem da política social se constituiu de um processo de mediação entre os diversos e conflitivos interesses da sociedade capitalista; as intervenções das políticas sociais se incumbem de tarefas que levam em consideração "tanto exigências quanto necessidades, tanto problemas de integração social quanto problemas de integração sistêmica, tanto a elaboração de conflitos de classe quanto a elaboração de crises do processo de acumulação" (OFFE. 1985, p.36). Assim, o surgimento de uma política social está envolto por interesses distintos que impactam os diversos atores da sociedade de maneira também distinta, fazendo com que a implementação das políticas sociais pelo Estado gere resultados não esperados, pois desencadeiam interesses conflitantes que estão presentes nas relações de poder instituídas na sociedade.

Nesse mesmo âmbito, as políticas sociais, como a educação, são formas de interferência do Estado na sociedade, assumindo determinados desenhos e contornos mediante as relações de forças em disputa. Assim, as políticas públicas em educação se materializam em determinadas condições históricas e sociais e são atravessadas por uma complexa teia que envolve interesses e concepções diversas, constituindo-se em um verdadeiro campo de forças em ação.

No Brasil, as reformas no campo educacional, da década de 90, seguiram a esteira da chamada Reforma do Estado, efetuadas pelo recém-criado Ministério da Administração e da Reforma do Estado (Mare), encabeçado por Bresser Pereira. Houve a substituição de um modelo de administração pública burocrática por um modelo gerencial. As reformas da administração pública redefiniram as relações, entre o público e o privado, por meio das mudanças no papel do Estado mediante a reestruturação do capitalismo mundial (PAULA, 2008).

A reforma apresentou uma nova configuração de administração pública em que o Estado “deixa de ser o responsável direto pelo desenvolvimento econômico e social pela via de produção de bens e serviços, para fortalecer-se na função de promotor e regulador desse desenvolvimento" (BRASIL, 1995, p, 17). O documento acentua a necessidade de reforçar a "governança" por meio de um modelo de transição que substitua a administração pública 
burocrática pela "administração pública gerencial, flexível e eficiente", que tem como exemplo a administração de empresas (BRASIL, 1995).

Para Ana Paula de Paula (2008), o modelo de administração pública gerencial está ligado aos debates sobre a crise dos Estados na América Latina, fomentados pela ideia de aumentar a produtividade e trazer a cultura do empreendedorismo para administração pública, isto é, um código de valores e condutas que orienta a organização das atividades, por meio das noções de eficiência, competitividade e qualidade total. A nova administração pública gerencial fez uma crítica ao modelo nacional-desenvolvimentista, pautado no papel central do Estado, para abraçar visões do desenvolvimento dependente e associado "que pretende fazer com que o país se desenvolva principalmente pela abertura de mercado e pela atração de investimentos externos" (PAULA, 2005, p.123). Essa foi a investida do governo brasileiro para aderir às recomendações do Consenso de Washington.

As atividades Estatais foram segmentadas em dois campos, a saber: atividades exclusivas do Estado: legislação, fiscalização, fomento, formulação de políticas públicas e avaliação; e atividades não exclusivas do Estado: atividades de caráter competitivo, prestadas pelo setor público ou privado (saúde, educação, assistência social), enquanto os serviços (limpeza, vigilância, transportes) seriam entregues à iniciativa privada por abertura de licitação (PAULA, 2008). A gestão pública, a partir de um modelo das empresas privadas, deveria buscar maior padrão de qualidade, eficiência e eficácia, a partir da racionalização dos recursos e de resultados obtidos por avaliações de impacto.

A reforma previu a promoção da competição entre os que prestam serviços públicos, a transferência do controle das atividades públicas para a comunidade, a orientação por objetivos e a focalização nos resultados. Ao Estado, caberia o papel de formular, fiscalizar e avaliar as políticas públicas, enquanto que sua operacionalização deveria ser terceirizada, estimulando a competição, aumentando, assim, seu padrão de qualidade. Para Paula (2008), o objetivo central era transformar a cultura burocrática em uma cultura gerencial. A educação, assim, é entendida como atividade não exclusiva do Estado, o que a coloca no campo das atividades competitivas que podem ser exercidas tanto pelo Estado como por terceiros.

A nova gestão pública foi adotada enquanto modelo administrativo para gestões públicas em todas as vertentes sociais, contemplando o sistema educacional. As reformas na educação seguiram as orientações da reforma do Estado e, por conseguinte, a qualidade da educação resultaria da adoção de uma gestão eficiente que estipulasse metas quantificáveis a serem atingidas por processos de avaliação. Esse evento consistiu em uma revisão curricular adequada de eficiência da gestão, da competitividade deflagrada por índices aferidos por 
avaliações externas, da descentralização dos sistemas de ensino e das novas formas de gestão com maior participação de todos os atores da sociedade (ARAÚJO e CASTRO, 2011). A gestão educativa gerencial parte do pressuposto de que há uma incapacidade do Estado em gerenciar seus imensos sistemas educativos, pois o excesso de verticalização das decisões resulta uma falta de autonomia e enfraquecimento da escola.

As reformas educacionais brasileiras, desde a década de noventa, vêm seguindo as cartilhas de organismos internacionais e baseiam-se no modelo de administração pública gerencial. A partir do governo de Fernando Henrique Cardoso, ocorreu uma aproximação abrupta a um modelo de educação para os resultados. Nesse contexto, as principais propostas para a educação consistiram em: "redução da responsabilidade do MEC como instância executora; estabelecimento de conteúdos curriculares básicos e padrões de aprendizagem; implementação de um sistema nacional de avaliação das escolas e do ensino" (ALTMANN, 2002, p.82).

Na visão de Alda Castro, a implementação do modelo gerencial na escola ocorreu pela definição de novas práticas de gestão e novas práticas pedagógicas, como o Plano de Desenvolvimento da Escola (PDE-escola), que propõe uma modernização da gestão e o fortalecimento da autonomia da escola, apoiado na noção de planejamento estratégico, racionalização e eficiência administrativa. Além disso, houve a formulação de sistemas de avaliação em todos os níveis de ensino e o uso da tecnologia para quantificar os desempenhos de todas as redes e escolas. Ainda segundo Castro, “A gestão gerencial é fortemente induzida pela lógica do controle dos resultados, em detrimento do controle dos processos organizacionais." (CASTRO, 2008, p.09).

As reformas dos anos 90 ficaram marcadas pelos processos de centralização e descentralização. O governo Federal ficou responsável pela definição de parâmetros curriculares nacionais e pela implantação de um sistema de avaliação institucional para todo o país. Enquanto isso, a gestão foi descentralizada, responsabilizando, assim, Estados e munícipios pelos resultados obtidos. A centralização/descentralização é permeada por uma combinação contraditória nos argumentos neoliberais. Propõe-se a descentralização dos sistemas de ensino, dos repasses dos fundos públicos e da gestão, enquanto propõe-se a centralização das reformas curriculares e do padrão de qualidade esperado nos sistemas de ensino aferidos por avaliações externas (GENTILI, 2002). É visível que essa contradição da gestão gerencial educacional gera uma falsa ideia de maior participação nas decisões da escola, quando, ao contrário, o que ocasiona é uma maior centralização no controle pedagógico, mais responsabilização em nível local e menor responsabilização do Estado nos resultados obtidos. 
Segundo Frigotto e Ciavatta (2003), a proposta educacional brasileira a partir da década de noventa passou a ser elaborada por intelectuais com passagem pelos organismos internacionais como o Banco Mundial. As reformas educacionais propostas, a partir de então, estruturam-se a partir dos consensos e orientações estabelecidas por estes organismos, e tiveram como objetivo prioritário, enquadrar a escola e as políticas em educação para uma formação que viesse a responder a nova divisão internacional do trabalho. Para os autores "O governo FHC, por intermédio do MEC adotou o pensamento e as diretrizes dos organismos internacionais e com isso trouxeram para o Brasil um modelo coerente com o ideário da desregulamentação, flexibilização, privatização e com o desmonte dos direitos sociais." (FRIGOTTO E CIAVATTA, 2003, p.108).

Para Libâneo (2012), as ideias neoliberais para a educação no Brasil surgem, ainda no governo Itamar Franco, com a elaboração do Plano Decenal Educação para Todos (1993 2003), que foi uma clara resposta do Brasil em consonância às concepções propagadas a partir da Conferência Mundial de Educação para Todos de Jontiem. O documento focalizou o ensino fundamental e o atendimento de necessidades mínimas de aprendizagens e de espaço de convivência e acolhimento social. Para o autor, as políticas educacionais subsequentes, tantos dos governos FHC como dos governos petistas, tiveram, como pano de fundo, a lógica dos documentos internacionais, em que a escolarização das camadas populares centraliza-se em aspectos comportamentais e assistenciais. "Constata-se, assim, que, com apoio em premissas pedagógicas humanistas por trás das quais estão critérios econômicos, formulou-se uma escola de respeito às diferenças sociais e culturais, às diferenças psicológicas de ritmo de aprendizagem, de flexibilização das práticas de avaliação escolar - tudo em nome da educação inclusiva.” (LIBÂNEO, 2012, p.23).

Libâneo não desconsidera, por razões morais e éticas, a necessidade de a escola cumprir funções sociais e assistenciais. Todavia, o autor argumenta que estas não podem ser as tarefas primordiais da escola. Para ele, "a escola é uma das mais importantes instâncias de democratização social e de promoção da inclusão social, desde que atenda à sua tarefa básica: a atividade de aprendizagem dos alunos" (LIBÂNEO, 2012, p.26). O que o autor denuncia é o surgimento de uma escola dual, na qual a formação das camadas desfavorecidas é enxergada apenas por meio do prisma do assistencialismo, o que corrobora com a visão de que aos pobres não serve o ensino acadêmico, mas sim ações de formação comportamental, compensatórias e assistencialistas.

A noção acima exposta fundamenta a perspectiva de educação integrada, na qual a melhoria da escolarização deve ser destinada (somente) aos pobres, para que suas carências, de 
ordem cultural, social ou cognitiva, sejam compensadas por meio da aquisição de competências e habilidades socioemocionais, e por meio de ações assistenciais de alívio à pobreza. Assim, as camadas populares desenvolveriam as qualidades demandadas à sociedade de mercado e as tensões sociais seriam encobertas.

Portanto, mediante as condições adversas de vida, dos jovens e crianças da periferia, a escola, não pode deixar de enxergar seus problemas sociais; todavia, a pobreza e as condições adversas não podem servir pretexto para uma escola não exigente do ponto de vista do aprendizado e focada em uma educação compensatória, pois assim, haveria uma descaracterização da papel da escola como instituição de aprendizado e ensino e de lugar de formação do pensamento em seu sentido pleno de reflexão e crítica.

Os governos Lula e Dilma (2003-2016), contrariando suas bandeiras históricas, não romperam com a educação pautada pela via neoliberal. Movimentos empresariais ganharam espaço na formulação de políticas públicas do cenário educacional. Seu principal representante, o Movimento Todos Pela Educação (TPE), teve papel fundamental na criação de documentos oficiais do Ministério da Educação (MEC), como as Metas Compromissos Todos pela Educação (MEC, 2007) e o Plano Nacional de desenvolvimento da Educação (PDE) (MEC, 2007).

\subsection{Os governos petistas e o empresariado nas políticas em educação}

A vitória de Luiz Inácio Lula da Silva para a presidência da república representou um marco na história política brasileira. $\mathrm{O}$ ex-operário foi uma das figuras centrais, nas décadas de 80 e 90, da esquerda brasileira. Em seus discursos, reiterava a luta dos trabalhadores e a necessidade de transformação da sociedade em prol da justiça social contra o capitalismo e suas desigualdades. Após disputar três eleições, Lula foi eleito em 2002, com mais de $60 \%$ dos votos válidos no segundo turno, desbancando o candidato do PSDB José Serra.

A possível chegada de Lula ao poder levou o pavor aos mercados. Uma possível vitória do PT traria uma política de ruptura aos interesses das classes dominantes e a instauração das ideias socialistas que balizavam o partido. No entanto, em 22 de junho de 2002, no auge da campanha eleitoral, o PT divulga a 'carta ao povo brasileiro', documento que alinhou o partido aos interesses do capital. Segundo Singer (2012), o documento, inicialmente, foi visto como estratégia de campanha, porém, cerca de um mês depois, suas diretrizes transformaram-se em orientações partidárias. 
Apesar do nome, a carta foi dirigida aos empresários e investidores estrangeiros. Nela, há um comprometimento com a manutenção dos compromissos fiscais e do superávit primário. O documento enfatiza aspectos econômicos e compromete-se em desenvolver uma gestão fiscal "responsável", em priorizar o "controle da inflação", em respeitar os "contratos nacionais e internacionais", em incentivar as exportações e em ampliar o mercado internacional. A carta termina com um claro sinal de conciliação com empresários e investidores e sinaliza um modelo de transição dentro da ordem capitalista, na qual a palavra socialismo foi abortada.

Há outro caminho possível. É o caminho do crescimento econômico com estabilidade e responsabilidade social. As mudanças que forem necessárias serão feitas democraticamente, dentro dos marcos institucionais. Vamos ordenar as contas públicas e mantê-las sob controle. Mas, acima de tudo, vamos fazer um Compromisso pela Produção, pelo emprego e por justiça social. O que nos move é a certeza de que o Brasil é bem maior que todas as crises. O país não suporta mais conviver com a idéia de uma terceira década perdida. O Brasil precisa navegar no mar aberto do desenvolvimento econômico e social. É com essa convicção que chamo todos os que querem o bem do Brasil a se unirem em torno de um programa de mudanças corajosas e responsáveis." (SILVA, 2002, n.p).

A ‘carta ao povo brasileiro' anunciou um projeto político ao qual André Singer (2012) denominou reforma gradual e pacto conservador. Para o autor, o reformismo fraco não é o abandono, mas sim a "diluição" do reformismo forte de tempos anteriores. As políticas de governo adotaram ações para a diminuição da desigualdade, sem confrontar os interesses do grande capital. Houve uma convivência pacífica entre as ideias originais do partido (espírito de Sion $)^{20}$ com os argumentos lançados pela ‘carta ao povo brasileiro' (espírito do Anhembi) ${ }^{21}$. O proposto foi uma reforma lenta e gradual, dentro da ordem vigente, em direção ao Estado de Bem-Estar brasileiro, o que vinha de encontro aos anseios do proletariado brasileiro e, ao mesmo tempo, acalmava as desconfianças da burguesia. Como resume Singer,

a convivência das duas almas do PT leva a paradoxos. O partido defende, simultaneamente, reformas estruturais profundas e a estabilidade econômica; a propriedade social dos meios de produção e o respeito aos contratos que garantem os direitos do capital; um postulado genérico anticapitalista e o apoio às grandes empresas capitalista; "a formação de uma cultura socialista de massas" e a aliança com partidos de direita. (SINGER, 2012, p.124).

\footnotetext{
${ }^{20}$ Singer refere-se ao encontro realizado no colégio Sion, em São Paulo, na data de 10 de fevereiro de 1980, que deu origem ao partido.

${ }^{21}$ Lugar onde Lula apresentou ao Brasil a ‘carta ao povo brasileiro'.
} 
Uma das teses centrais da análise de Singer é que o governo de Lula tenha compreendido as aspirações do subproletariado ${ }^{22}$. Essa fração da classe operária deseja o protagonismo do Estado em ações de combate à pobreza, porém dentro da ordem. O desejo do subproletariado é proletarizar-se, isto é, ele deseja ser incorporado ao mercado formal de trabalho, deseja receber salários que garantam um padrão mínimo de consumo e deseja gozar das garantias que o Estado concede a esses trabalhadores. Portanto, o governo avançou em um programa que atendeu aos desejos dessa fração da sociedade, que se constitui na principal força de apoio do governo.

O governo Lula unificou muitos dos programas de transferência de renda da gestão anterior, como o Bolsa Escola, o Bolsa Alimentação, o Vale Gás e o Cartão Alimentação, criando, assim, o programa Bolsa Família, instituído pela lei 10.836 de 2004, que se constitui na ação mais popular do governo. Singer aponta que o tripé formado pelo Bolsa Família, pelo salário mínimo e pela expansão de crédito foram fatores fundamentais para a redução da pobreza no período lulista. Para o autor,

O projeto de combate à pobreza acabou por se firmar sobre quatro pilares: transferência de renda para os mais pobres, ampliação do crédito, valorização do salário mínimo, tudo isso resultando em aumento do emprego formal. Se discernirmos com isenção, percebemos que são, de forma atenuada, as mesmas propostas do 'reformismo forte', porém em versão homeopática, diluídas em altas doses de excipiente, para não causar confronto. (SINGER, 2012, p.189).

A necessidade em manter as políticas de governo dentro da ordem fizeram com que o foco central das ações dos governos petistas fosse a pobreza e não a desigualdade. Singer aponta que o reformismo fraco tem como meta a superação da pobreza, ao passo que o reformismo forte buscava a superação da desigualdade. Essa observação nos permite argumentar que o reformismo fraco, centrado no combate à pobreza extrema, pode ser enxergado na esteira do discurso "humanizado" do Banco Mundial e outros organismos internacionais.

Os governos do PT ficaram marcados pela aproximação com o empresariado nacional, a partir de novas alianças, nas quais a relação entre Estado e sociedade é cada vez mais perpassada pelos interesses privados no seio do governo. Para Armando Boito Júnior (2007), sem romper com a hegemonia do grande capital financeiro internacional, os governos de Lula da Silva promoveram a ascensão política da burguesia nacional. O governo, além de ter tido o

\footnotetext{
${ }^{22}$ Os subproletários seriam aqueles trabalhadores que "oferecem a sua força de trabalho no mercado sem encontrar quem esteja disposto a adquiri-la por um preço que assegure sua reprodução em condições normais" (Singer, P., 1982, p.22, apud Singer, A., 2012, p.77).
} 
empresário José Alencar na vice-presidência, ainda contou com outros empresários que integraram a equipe ministerial e outros órgãos de governo ${ }^{23}$.

Boito, em contraposição a Singer, enxerga que os governos do PT não são arbítrios entre as classes e não são governos do subproletariado, mas sim governos burgueses, especificamente da burguesia nacional. Para Boito, "Na verdade a grande burguesia interna, nas suas disputas com a fração burguesa perfeitamente integrada ao grande capital financeiro internacional, converteu-se em força dirigente de uma ampla e heterogênea frente política que poderíamos denominar neodesenvolvimentista" (BOITO, 2013, p.171). Contudo, o autor expõe que esses trabalhadores marginalizados, embora excluídos dos processos decisórios, foram beneficiados com uma série de programas sociais, habitacionais e de distribuição de renda. Ele também pontua que esses ganhos foram desiguais, uma vez que "os programas de transferência de renda para a população trabalhadora são muito tímidos quando comparados com os "programas de transferência de renda" para os rentistas e para as grandes empresas que usufruem do financiamento farto e subsidiado pelo BNDES.” (BOITO, 2013, p.178).

Embora seja um consenso os avanços na criação de empregos, na geração de renda e nas políticas e programas sociais que focaram os mais pobres, os governos do PT caracterizaram-se por uma política de conciliação e abertura aos interesses neoliberais, logo, não houve ruptura com os interesses da burguesia e sim uma política de conciliação. Uma combinação de elementos neoliberais e outros completamente não neoliberais. Sendo assim, configurou-se em um reformismo que atendeu a interesses sociais contraditórios.

Na educação, assistimos à inserção do empresariado nos processos decisórios e na delineação de políticas públicas. A educação também foi marcada por uma política de consensos e alianças contraditórias. A não ruptura com a gestão pública educacional gerencial abriu espaço para maior inserção de grandes grupos empresariais na educação pública brasileira, mediante o discurso do comprometimento de todos os atores sociais pela educação, em uma concepção de "que cada um faça sua parte". Nos últimos anos, cresce a noção de empresas cidadãs e socialmente responsáveis que atuam diretamente em áreas como assistência social e educação. A inserção cada vez mais efetiva das empresas em ações sociais pauta-se no “objetivo de difundir referências materiais e simbólicas para consolidar padrões de sociabilidades afinadas com as necessidades do capitalismo contemporâneo." (MARTINS, 2005, p.2).

\footnotetext{
${ }^{23}$ Como Roberto Rodrigues, então presidente da ABAG (Associação Brasileira de Agrobusiness) para a pasta de agricultura.
} 


\subsubsection{A ação do empresariado na educação brasileira e a formulação do PDE}

O movimento Todos pela Educação (TPE) foi criado por um grupo de intelectuais que se reuniram, em 2005, para refletir sobre a qualidade da educação brasileira. O grupo verificou que a baixa qualidade da educação trazia vários problemas para a capacidade competitiva do país (MARTINS, 2005). O TPE surgiu em 2006 e concebe-se como uma aliança nacional apartidária entre iniciativa privada, organizações sociais e governos. Está associado a grupos empresariais como Grupo Itaú, Gerdau, Pão de Açúcar, Instituto Ayrton Senna, Grupo de Institutos, Fundações e Empresas - GIFE, Fundação Roberto Marinho, Instituto Ethos e Grupo Abril (MARTINS, 2013).

Segundo Erika Martins (2013), sua origem pode ser interpretada como parte de um contexto de mudança na relação entre sociedade e Estado, na esteira das reformas da administração pública da década de 90, em que o papel do Estado é redefinido e ocorre a promoção do Terceiro Setor por meio da proliferação de ONGs, institutos e fundações, apresentando como justificativas discursos baseados em expressões como "responsabilidade social e empresarial", "investimento social privado", "voluntariado", "parceria entre o público e o privado".

Para legitimar-se, o TPE utilizou como estratégia o estabelecimento de alianças com grupos empresariais, instituições sociais e governo. O grupo apropriou-se de reinvindicações históricas para a educação, incorporou novas pautas e trouxe como justificativa para sua atuação sua experiência empresarial (MARTINS, 2013). Martins aponta o movimento TPE como uma grande teia que, a partir de um núcleo composto por empresas privadas, estende seus vínculos com ONGS, associações da sociedade civil, imprensa, organismos internacionais, universidades públicas e privadas, órgãos da administração pública, políticos e MEC. O alcance de suas propostas, além de definir as políticas públicas em educação, indica a tentativa de estabelecer um verdadeiro consenso, em torno de suas prerrogativas, como as soluções reais para melhorar a qualidade da educação. Luís Carlos Freitas aponta que a ação do empresariado e dos organismos internacionais, nos anos recentes, a partir do que denominou a segunda ${ }^{24}$ onda neoliberal na educação, pode ser entendida de modo a que:

Estes atores, embora antigos, atuam agora com maior força dentro dos órgãos nacionais de elaboração de políticas educacionais, Ministérios, Congresso Nacional e articulam expressivo apoio da mídia liberal/conservadora, que veicula cotidianamente suas propostas, sem contar o apoio de inúmeras

\footnotetext{
${ }^{24}$ Segundo a autor, a primeira onda neoliberal na educação teria ocorrido na década de 90 (FREITAS, 2014).
} 
empresas educacionais de consultoria, ONGs e institutos privados. (FREITAS, 2014, p.1106).

O Movimento Todos Pela Educação promove cinco metas a serem alcançadas até 2022. Sendo elas:

Meta 1-Toda criança e jovem de 4 a 17 anos na escola; Meta 2-Toda criança plenamente alfabetizada até os 8 anos; Meta 3-Todo aluno com aprendizado adequado ao seu ano; Meta 4-Todo jovem de 19 anos com ensino médio concluído; Meta 5- Investimento em Educação ampliado e bem gerido Aperfeiçoamento da gestão e da governança em Educação ${ }^{25}$.

Apesar das metas que incidem sobre características fundamentais à justa promoção de oportunidades na educação, a de número 5 entende que aspectos gerenciais são fundamentais para o alcance dos objetivos anteriores, entendendo-se como maior influência do modelo empresarial nas políticas em educação. A aliança entre setor público, privado e sociedade civil redefinem as fronteiras dos espaços públicos e privados, em um movimento em que não há clareza das delimitações de cada âmbito. O TPE propõe aliar práticas de mercado com justiça social, se auto denominando como arauto de interesses comuns entre todas as classes, a partir da causa educacional.

Como aponta Freitas, o empresariado, em seu discurso social, imbuiu-se de uma missão civilizatória e salvadora, na qual:

[...] se sentem os "novos colonizadores" que trarão a "boa cultura" às camadas populares imersas na pobreza, na qual mergulharam por demérito próprio ou falta de oportunidade. A isso chamam de "responsabilidade social das empresas". Com isso, tiram o foco da pobreza que eles mesmos geram e colocam os holofotes, primeiramente, sobre a escola. (FREITAS, 2014, p.1090).

Gentili aponta que a inserção dos empresários, na discussão educacional, vem do pressuposto da ineficiência do Estado em garantir e gerenciar uma educação de qualidade. Parte-se da ideia de que o Estado protetor e provedor criou uma profunda indisciplina social, perdendo-se o componente que dá sustento à competição e ao mérito, perdeu-se a ética individualista que reconhece o esforço e a cultura do trabalho. Portanto, mediante à improdutividade e ineficiência dos sistemas educacionais, os empresários deveriam ser consultados para nos relegar suas “fórmulas de sucesso" (GENTILI, 2002).

\footnotetext{
${ }^{25}$ Texto retirado da página eletrônica do Movimento Todos pela Educação, acessado em 05 de julho de 2018 http://www.todospelaeducacao.org.br/indicadores-da-educacao/5-metas.
} 
Em sintonia e consonância com as metas estipuladas pelo TPE, o Ministério da Educação criou, em 2007, o Plano de Metas Todos Pela Educação que foi, na visão de Saviani, o "carro-chefe" da implementação do Plano de desenvolvimento da Educação (PDE), no mesmo ano (SAVIANI, 2007).

O PDE surgiu como medida para instrumentalizar as metas do Plano Nacional de Educação (PNE). O PDE é composto por mais de quarenta programas e ações dispostos em quatro grupos: educação básica, educação superior, educação profissional e alfabetização. Assume uma visão sistêmica em contraposição a uma visão "fragmentada" das políticas do governo FHC (KRAWCZYK, 2008). As ações do PDE englobam estratégias para todos os níveis de ensino. Ele tem como eixo central o piso salarial nacional dos professores do magistério e o IDEB (Índice da Educação básica) e, como objetivo geral, prevê a mobilização social pela melhoria da qualidade da educação básica. Segundo o texto da lei, o PDE:

pretende ser mais do que a tradução instrumental do Plano Nacional de Educação (PNE), o qual, em certa medida, apresenta um bom Planejamento e Práticas da Gestão Escolar, mas deixa em aberto a questão das ações a serem tomadas para a melhoria da qualidade da educação. É bem verdade, como se verá em detalhe a seguir, que o PDE também pode ser apresentado como plano executivo, como conjunto de programas que visam dar conseqüência às metas quantitativas estabelecidas naquele diploma legal, mas os enlaces conceituais propostos tornam evidente que não se trata, quanto à qualidade, de uma execução marcada pela neutralidade. Isso porque, de um lado, o PDE está ancorado em uma concepção substantiva de educação que perpassa todos os níveis e modalidades educacionais e, de outro, em fundamentos e princípios historicamente saturados, voltados para a consecução dos objetivos republicanos presentes na Constituição, sobretudo no que concerne ao que designaremos por visão sistêmica da educação e à sua relação com a ordenação territorial e o desenvolvimento econômico e social. (BRASIL, 2007a, p.7).

O PDE está sustentado em seis pilares conceituais: visão sistêmica da educação, territorialidade, desenvolvimento, regime de colaboração, responsabilização e mobilização social (PDE, 2007a). Segundo a abordagem sistêmica, os sistemas não podem ser compreendidos plenamente apenas pela análise separada e exclusiva de cada uma de suas partes. É preciso compreendê-los como dependentes e inter-relacionados uns aos outros. No PDE (p.10), a visão sistêmica da educação reconhece "as conexões intrínsecas entre educação básica, educação superior, educação tecnológica e alfabetização [...] para potencializar as políticas de educação que se reforcem reciprocamente".

Segundo Nora Krawczyk (2008), os eixos fundamentais do PDE constituem-se pela responsabilização da classe política, juntamente com os gestores e docentes para a mobilização 
social em torno da educação; constituem-se também por ações intergovernamentais, mediante a articulação de diferentes ministérios em torno de políticas de equalização social; constituemse ainda pela definição das unidades escolares como eixo norteador de políticas públicas e constituem-se, por fim, pela ideia de escola como centro cultural e de encontro comunitário. Segundo o MEC,

O PDE promove profunda alteração na avaliação da educação básica. Estabelece, inclusive, inéditas conexões entre avaliação, financiamento e gestão, que invocam conceito até agora ausente do nosso sistema educacional: a responsabilização e, como decorrência, a mobilização social. (Brasil, 2007a, p.19).

Uma das ações centrais do PDE foi a criação do IDEB que se apresenta, no endereço eletrônico o INEP, como uma "iniciativa pioneira de reunir em um só indicador dois conceitos igualmente importantes para a qualidade da educação: fluxo escolar e médias de desempenho nas avaliações." (INEP) ${ }^{26}$. O IDEB vem definindo a criação e manutenção de políticas públicas nos últimos anos e acompanha uma tendência internacional, que enxerga a avaliação como estratégia para aumentar a competição entre escolas e sistemas de ensino e, assim, propulsionar melhorias nos índices internacionais.

Para Krawczyk (2008), o PDE anuncia um novo modelo de regulação estatal, em que o Estado se compromete em diminuir as disparidades regionais em educação pelo país. O governo Federal passa a exercer papel de regulador das desigualdades existentes entre as regiões "por meio de assistência técnica e financeira, de instrumentos de avaliação e de implementação de políticas que ofereçam condições e possibilidades de equalização das oportunidades de acesso à educação de qualidade" (KRAWCZYK, 2008, p.802). Em contrapartida, os Estados e os municípios serão responsabilizados pelos resultados obtidos em seus sistemas de ensino.

Assim, da revisão do papel do governo federal resulta um controle maior e sistemático das políticas nos entes federados; o atrelamento dos recursos próprios do MEC aos resultados do Ideb; a interlocução direta com as unidades escolares, por meio, principalmente, da definição de metas para cada uma delas e da manutenção do Programa Dinheiro Direto na Escola, iniciado no governo de Fernando Henrique Cardoso, que associa recursos adicionais à aprovação do projeto pedagógico da instituição. (KRAWCZYK, 2008, p.805).

O PDE tem como uma de suas estratégias a territorialidade, isto é, priorizam-se recursos financeiros, via PDDE (programa dinheiro direto na escola), às unidades escolares com baixos

${ }^{26}$ Acessado em 02 de julho de 2018 http://portal.inep.gov.br/web/portal-ideb/o-que-e-o-ideb. 
rendimentos no IDEB. A liberação dos recursos é condicionada a um plano de gestão com ações efetivas para melhorar o baixo desempenho. O MEC disponibiliza a apoio técnico para as unidades escolares que encontrarem dificuldades para a elaboração do plano de metas. Além disso, o PDDE ainda prevê recursos adicionais para as escolas que atingirem as metas do IDEB. O recebimento de verbas atreladas aos índices do IDEB gera efeitos perversos, pois "acumulamse "diagnósticos" que servem mais para cumprir burocraticamente a condição estipulada para o recebimento de recursos financeiros do poder público do que para orientar as ações e encontrar saídas" (KRAWCZYK, 2008, p.808).

A adesão ao PDE ocorre por meio da assinatura do Plano de Metas Compromisso Todos Pela Educação, decreto 6094/2007. O documento estabeleceu 28 diretrizes, que versam sobre aspectos de acesso e permanência, organização do trabalho pedagógico, formação e valorização da carreira docente, gestão e participação e parcerias com os setores privados. Destacamos as diretrizes de número XXVII E XXVIII:

XXVII - firmar parcerias externas à comunidade escolar, visando a melhoria da infraestrutura da escola ou a promoção de projetos socioculturais e ações educativas;

XXVIII- organizar um comitê local do Compromisso, com representantes das associações de empresários, trabalhadores, sociedade civil, Ministério Público, Conselho Tutelar e dirigentes do sistema educacional público, encarregado da mobilização da sociedade e do acompanhamento das metas de evolução do IDEB. (BRASIL, 2007b, n.p).

O compromisso, citado no título do documento, constitui-se de um contrato ao que estados e municípios devem assumir para receber transferências financeiras voluntárias e assistência técnica. Para a adesão é requerido um plano de atividades articuladas (PAR), municipal ou estadual. O PAR é um instrumento de planejamento plurianual, que se define como conjunto articulado de ações de responsabilidade conjuntas entre estados, municípios e Federação (BRASIL, 2007c). As ações do PDE e do PAR são acompanhadas pelo Sistema de Monitoramento (SIMEC).

O plano de metas faz um chamado para que as comunidades, famílias e empresários envolvam-se com a qualidade da educação, no intuito de viabilizar projetos e iniciativas que o Estado, sozinho, não seria capaz de cumprir. O Compromisso Todos Pela Educação norteou a criação do PDE que, no dizer de Saviani, traz consigo recomendações do empresariado para a educação brasileira.

O PDE assume plenamente, inclusive na denominação, a agenda do Compromisso Todos pela Educação, movimento lançado em 6 de setembro 
de 2006 no Museu do Ipiranga, em São Paulo. Apresentando-se como uma iniciativa da sociedade civil e conclamando a participação de todos os setores sociais, esse movimento se constituiu, de fato, como um aglomerado de grupos empresariais com representantes e patrocínio de entidades como o Grupo Pão de Açúcar, Fundação Itaú-Social, Fundação Bradesco, Instituto Gerdau, Grupo Gerdau, Fundação Roberto Marinho, Fundação Educar DPaschoal, Instituto Itaú Cultural, Faça Parte-Instituto Brasil Voluntário, Instituto Ayrton Senna, Cia. Suzano, Banco ABN-Real, Banco Santander, Instituto Ethos, entre outros. (SAVIANI, 2007, p.1242).

Para Libâneo et all (2015), ao não ser uma ação amplamente discutida com a sociedade e ao apoiar-se unicamente nas recomendações do empresariado o modelo sistêmico do PDE é caracterizado por preceitos empresariais e não educativos, como "eficácia, eficiência e qualidade total". Portanto,

A busca da eficiência (economia de recursos), da eficácia (adequação do produto), enfim, da excelência e da qualidade total, para levar o sistema de ensino a corresponder às necessidades do mundo atual, apresenta como solução o enfoque sistêmico (que procura otimizar o todo) [..] Manifesta-se , desse modo, a tentativa de vincular a educação ao novo paradigma produtivo, na ótica do que se denomina neotecnicismo." (LIBÂNEO ET ALL, 2015 p.104).

Para Jamerson Silva e Katharine Silva, o PDE, ao propor um modelo sistêmico de gestão, caracteriza-se por um modelo empresarial e gerencial em que a educação está centrada nos resultados aferidos por índices de qualidade, isto é, por meio das varáveis de matrículas, permanência e resultados nas avaliações externas. O PDE, ao optar pelo modelo sistêmico, "parece querer transportar o modelo empresarial para a educação, em sintonia com a lógica das reformas dos anos noventa" (SILVA e SILVA 2012, p.32). 


\section{O PROGRAMA MAIS EDUCAÇÃO E NOSSAS ANÁLISES}

\subsection{O discurso legal da educação integral}

A legislação, que orienta e antecede a construção do PME, é constituída por: Constituição Federal; Estatuto da Criança e do Adolescente (Lei nº 9089/1990); Lei de Diretrizes e Bases (Lei no 9394/1996); Plano Nacional de Educação (Lei no 10.179/01) e Fundo Nacional de manutenção e Desenvolvimento do Ensino Básico e de Valorização do Magistério (Lei no 11.494/2007).

A Constituição Federal de 1988 aponta a educação como o primeiro de uma série de direitos sociais elencados. Esse direito configura-se a partir de sua nova redação, por meio da emenda constitucional n²6, de 2000, Art. $6^{\circ}$ : "São direitos sociais a educação, a saúde, a alimentação, o trabalho, a moradia, o transporte, o lazer, a segurança, a previdência social, a proteção à maternidade e à infância, a assistência aos desamparados, na forma desta Constituição" (BRASIL 1988, p.18). Segundo seu artigo 205, “A educação, direito de todos e dever do Estado e da família, será promovida e incentivada com a colaboração da sociedade, visando ao pleno desenvolvimento da pessoa, seu preparo para o exercício da cidadania e sua qualificação para o trabalho.” (BRASIL, 1988, p. 123).

O Estatuto da Criança e do Adolescente (ECA) alicerça a ideia de proteção integral como dever da família, da comunidade, da sociedade em geral e do poder público, garantindo os direitos das crianças e jovens:

Art. $4^{\circ}$ : É dever da família, da comunidade, da sociedade em geral e do poder público assegurar, com absoluta prioridade, a efetivação dos direitos referentes à vida, à saúde, à alimentação, à educação, ao esporte, ao lazer, à profissionalização, à cultura, à dignidade, ao respeito, à liberdade e à convivência familiar e comunitária. (BRASIL, 1990, n.p).

A Constituição Federal de 1988 e o ECA ressaltam a noção de que crianças e adolescentes são portadores de direitos; atestam também o entendimento de que a proteção integral deles deve ser garantida por meio de ações compartilhadas entre Estado, família e Sociedade.

A lei de Diretrizes e Bases da Educação Nacional, Lei n 9394/96, assegura que o tempo mínimo de escolarização no ensino fundamental deve ser de quatro horas por dia de trabalho em sala de aula, devendo ser progressivamente aumentado para o tempo integral, a critério dos sistemas de ensino: 
Art. $34^{\circ}$ : A jornada escolar no ensino fundamental incluirá pelo menos quatro horas de trabalho efetivo em sala de aula, sendo progressivamente ampliado o período de permanência na escola;

[...]

$\S 2^{\circ}$ : O ensino fundamental será ministrado progressivamente em tempo integral, a critério dos sistemas de ensino (BRASIL, 1996, n.p).

E em seu artigo 87, encontra-se:

$\S 5^{\circ}$ : Serão conjugados todos os esforços objetivando a progressão das redes escolares públicas urbanas de ensino fundamental para o regime de escolas de tempo integral. (BRASIL, 1996, n.p).

O primeiro Plano Nacional de Educação, Lei n 10172/01, PNE (2001-2010), instituiu metas para efetivar ações da União, dos Estados e dos municípios para a ampliação da jornada escolar para o turno integral. No texto da lei, o desenvolvimento integral do estudante tem o intuito de diminuir as desigualdades sociais e ampliar as oportunidades de aprendizagem. Conforme o plano, as classes de aceleração e o turno integral são ações efetivas para a diminuição da repetência. A meta de ampliação progressiva deve ser para sete horas diárias. Defendendo essa prerrogativa, lê-se:

A ampliação da jornada escolar para turno integral tem dado bons resultados. $\mathrm{O}$ atendimento em tempo integral, oportunizando orientação no cumprimento dos deveres escolares, prática de esportes, desenvolvimento de atividades artísticas e alimentação adequada, no mínimo em duas refeições, é um avanço significativo para diminuir as desigualdades sociais e ampliar democraticamente as oportunidades de aprendizagem. (BRASIL, 2001, n.p).

O Decreto $n^{\circ}$. 6.253/07, que dispõe sobre o Fundo de Manutenção e Desenvolvimento da Educação Básica e de Valorização dos Profissionais da Educação - FUNDEB - definiu, em seu Art. $4^{\text {o }}$, que

considera-se educação básica em tempo integral a jornada escolar com duração igual ou superior a sete horas diárias, durante todo o período letivo, compreendendo o tempo total que um mesmo aluno permanece na escola ou em atividades escolares. (BRASIL, 2007, n.p.).

O segundo Plano Nacional de Educação, Lei n 13005/14, PNE (2014-2024), propõe, em sua meta de número seis, oferecer educação em tempo integral em, no mínimo, 50\% (cinquenta por cento) das escolas públicas, de forma a atender, pelo menos, $25 \%$ (vinte e cinco por cento) dos(as) alunos(as) da educação básica” (BRASIL, 2014). 
O PME surgiu como estratégia do PDE para operacionalizar as metas do PNE (20012011). O Programa Mais Educação foi instituído pela portaria Interministerial $n^{\circ} 17 / 2007$, regulamentado pelo decreto 7.083/2010, coordenado pela Secretária de Educação Básica (SEB/MEC), em parceria com as Secretárias Estaduais e Municipais de Educação. O programa integra as ações do Plano de Desenvolvimento da Educação (PDE) no âmbito do Plano de Metas Compromisso Todos pela Educação (Decreto $n^{\circ}$ 6.094, de 24 de abril de 2007). Até 2011, esteve sob coordenação da Secretaria de Educação Continuada, Alfabetização, Diversidade e Inclusão do Ministério da Educação (SECAD/MEC). O financiamento é de responsabilidade do Fundo Nacional de Desenvolvimento da Educação (FNDE), por meio do Programa Dinheiro Direto na Escola (PDDE) e do Programa Nacional de Alimentação Escolar (PNAE).

Sua portaria de criação descreve que o PME se constitui de uma proposta indutora de educação integral em tempo integral, como expõe os seguintes trechos: "Instituir o Programa Mais Educação, com o objetivo de contribuir para a formação integral de crianças, adolescentes e jovens" (BRASIL, 2007b, grifos nossos, n.p) “apoiar a ampliação do tempo e do espaço educativo e a extensão do ambiente escolar nas redes públicas de educação básica de Estados, Distrito Federal e municípios, mediante a realização de atividades no contraturno escolar." (BRASIL. 2007b, grifos nossos, n.p).

Neste documento, é definido que o programa visa o atendimento de crianças em situação de vulnerabilidade social a partir de um modelo de gestão intersetorial:

CONSIDERANDO a situação de vulnerabilidade e risco a que estão submetidas parcelas consideráveis de crianças, adolescentes e jovens e suas famílias, relacionadas à pobreza, discriminação étnico-racial, baixa escolaridade, fragilização de vínculos, trabalho infantil, exploração sexual e outras formas de violação de direitos;

CONSIDERANDO o caráter intersetorial das políticas de inclusão social e formação para a cidadania, bem como a co-responsabilidade de todos os entes federados em sua implementação e a necessidade de planejamento territorial das ações intersetoriais, de modo a promover sua articulação no âmbito local (BRASIL, 2007b, n.p).

Ainda segundo seu documento inaugural, as melhorias do rendimento escolar e a defasagem idade/série (isto é, os critérios do IDEB) são finalidades do PME, como aponta o trecho a seguir, “contribuir para a redução da evasão, da reprovação, da distorção idade/série, mediante a implementação de ações pedagógicas para melhoria de condições para o rendimento e o aproveitamento escolar" (BRASIL, 2007b, n.p). 
De acordo com o Decreto 7.083, de 2010, em seu artigo $3^{\circ}$, os objetivos do Programa são:

I - formular política nacional de educação básica em tempo integral;

II - promover diálogo entre os conteúdos escolares e os saberes locais;

III- favorecer a convivência entre professores, alunos e suas comunidades;

IV -disseminar as experiências das escolas que desenvolvem atividades de educação integral;

$\mathrm{V}$ - convergir políticas e programas de saúde, cultura, esporte, direitos humanos, educação ambiental, divulgação científica, enfrentamento da violência contra crianças e adolescentes, integração entre escola e comunidade, para o desenvolvimento do projeto político-pedagógico de educação integral. (BRASIL, 2010, n.p).

Para nortear a conceituação, a operacionalização e a implementação do PME, o MEC publicou, em 2009, a Série Mais Educação. A trilogia é composta pelos cadernos Gestão intersetorial no território, Educação Integral e Rede de Saberes Mais Educação. O caderno Gestão Intersetorial aborda os marcos legais do PME, compreensões acerca da educação integral, concepções sobre a gestão intersetorial e sua operacionalização, programas ministeriais que compõem o PME e os modelos de participação a serem implementados nas diferentes esferas que envolvem o programa (BRASIL, 2009a).

O segundo, Educação Integral, foi um trabalho coletivo promulgado com o intuito de ser referência no debate nacional de educação integral. Esse trabalho envolveu grupos "convocados" pelo SECAD, gestores e educadores federais, estaduais e municipais, membros da Confederação Nacional de Trabalhadores da Educação (CNTE), representantes da União Nacional dos Dirigentes Municipais de Educação (UNDIME), do Conselho Nacional dos Secretários da Educação (CONSED), da Associação Nacional pela Formação de Profissionais da Educação (ANFOPE), além de universidades públicas e organizações não governamentais, como o CENPEC (BRASIL, 2009b).

O terceiro caderno, Rede de Saberes, traz os pressupostos teóricos em que se fundamenta a educação integral no PME: diálogo entre saberes escolares e saberes comunitários, as noções de educação intercultural e as "Mandadas de Saberes", estas últimas como símbolo da possiblidade de uma proposta interministerial, intersetorial e intercultural (que tem como resultado situações integradas de aprendizagem) (BRASIL, 2009c).

No caderno Caminhos para Elaborar uma proposta de Educação Integral em jornada ampliada, (BRASIL, 2011), o texto traz diretrizes para a implementação da educação integral e conceituações sobres a educação integral. O material também foi produzido com ampla participação de profissionais e representantes da educação nas esferas federal, estadual e 
municipal, universidades públicas e associações da sociedade civil. O Mais Educação Passo a Passo, (BRASIL, 2013), veio ao público em 2013 e constitui-se de um manual elaborado para as unidades escolares, com perguntas e respostas básicas sobre o PME.

\subsection{Conceitos e fundamentações do Programa Mais Educação}

A partir dos cadernos da Série Mais Educação e de outros documentos, como o caderno Mais Educação Passo a Passo e o caderno Caminhos para Elaborar uma proposta de Educação Integral em jornada ampliada, além de textos publicados por Jaqueline Moll (2011) e Jaqueline Moll ${ }^{27}$ e Jesuína Leclerc (2012), propor-nos-emos, a seguir, a levantar os conceitos que estruturam o PME.

O PME trouxe a missão de delinear uma política de educação integral nacional em consonância com a ampliação da jornada escolar por meio de atividades no contraturno em diferentes macrocampos ${ }^{28}$ : acompanhamento pedagógico; educação ambiental; esporte e lazer; direitos humanos em educação; cultura e artes; cultura digital; promoção da saúde; comunicação e uso de mídias; investigação no campo das ciências da natureza e educação econômica.

No período de matrícula, os estudantes cursam as disciplinas do currículo tradicional, enquanto que, no contraturno, são desenvolvidas as atividades dos diferentes macrocampos promovidas pelo programa. No turno fixo "prevalecem as disciplinas tradicionais, que constituem o núcleo duro do currículo e, por outro, os contraturnos flexíveis, em que prevalecem as atividades que procuram tornar o tempo escolar mais agradável." (MOLL E LECLERC, 2012 p.97).

As oficinas podem ocorrer dentro do espaço escolar ou fora dele. Além da escola, as atividades podem ocorrer em igrejas, praças, centros comunitários e associações. Também são aconselhadas saídas de campo a fim de que os alunos tenham contato com os equipamentos culturais de sua cidade ou de outros locais. Segundo o MEC (2009c), a educação tem a escola como ator central, todavia, há a necessidade de articular outras políticas públicas que contribuam para a diversidade de vivências. O uso de diferentes espaços, com o estabelecimento

\footnotetext{
${ }^{27}$ Jaqueline Moll foi diretora de Currículos e Educação Integral da Secretaria de Educação Básica no MEC de 2007 a 2013 e foi uma das principais idealizadoras do PME.

${ }^{28}$ Por macrocampos se entende um "conjunto de vivências, linguagens e conhecimentos disciplinares incorporados ao currículo por legislação, por iniciativas locais, por políticas intersetoriais e outras iniciativas, que abrem possibilidades de ampliação e ressignificação do tempo diário de/na escola” (MOLL, 2012).
} 
de parceiras, estimula a articulação entre escola e comunidade e possibilita o enfretamento da distância entre a escola e a comunidade.

Segundo os documentos, a educação abrange muitos espaços e atividades sociais para além da escola, todavia, a responsabilidade formal de educar foi atribuída à escola, o que implicou um distanciamento com a comunidade. Surge daí a necessidade de ações integradas e compartilhadas com a sociedade.

O projeto pressupõe parcerias entre a escola, a família, o poder público e as organizações sociais no levantamento das potencialidades educativas do território no qual a escola se encontra. Há a rejeição da escola como instituição total, logo, a formação integral deve, também, ultrapassar seus muros, a partir do mapeamento e gerenciamento de trilhas educativas que são "percursos pelos quais o processo pedagógico se estende, extrapolando a sala de aula e incluindo praças, parques, ateliês, becos, estúdios, oficinas, empresas, museus, teatros, cinemas, parques de diversão, centros esportivos, bibliotecas, livrarias, entre outros." (ASSOCIAÇÃO CIDADE APRENDIZ, 2007, p.9).

A reformulação do currículo parte da concepção do diálogo entre os saberes escolares e os saberes comunitários. Por saberes comunitários é entendido o "universo cultural local, isto é, tudo aquilo que nossos alunos trazem para a escola, independentemente de suas condições sociais" (BRASIL, 2009c, p.37). Esses saberes são divididos em habitação, corpo/vestuário, alimentação, brincadeiras, organização política, condições ambientais, mundo do trabalho, curas e rezas, expressões artísticas, narrativas locais e calendário (BRASIL, 2009c). Nesta visão, a escola deve romper a dicotomia entre o currículo tradicional e os saberes do cotidiano, fazendo desaparecer a relação hierárquica entre o conhecimento científico e o cotidiano. O currículo deve possibilitar o diálogo entre diferentes culturas, estabelecendo uma educação intercultural.

\footnotetext{
A interculturalidade remete ao entrelaçamento, àquilo que acontece quando os grupos entram em relação de trocas. Os contextos interculturais permitem que os diferentes sejam o que realmente são nas relações de negociação, conflito e reciprocidade. Escola e comunidade são desafiadas a se expandirem uma em relação a outra e se completarem. (BRASIL, 2009, p.21).
}

Traz-se a compreensão de que a educação, além de reconhecer as diferenças, precisa corrigir desigualdades e promover ambientes de troca. Diante da riqueza e diversidade cultural, faz-se necessário recusar um único ponto de vista, no qual o diferente é, muitas vezes, compreendido pelo ponto de vista da carência. "Os sujeitos estão situados no meio de espaços de diferenças de classe, gênero, e sem dúvida cabe a nós, educadores, promover a comunicação entre os diversos saberes e práticas” (BRASIL, 2009c, p.4). 
A aproximação com a comunidade é uma das principais proposições do PME. A comunidade, nesta visão, é enxergada como "agente educador" e, ao mesmo tempo, como sujeito que se educa. Parte-se da noção de que a escola está inserida um uma comunidade com especificidades culturais e que para a construção de uma proposta de educação integral essas especificidades devem ser reconhecidas (BRASIL. 2009c).

A educação integral presente nos documentos considera o educando como elemento central da prática pedagógica. As atividades desenvolvidas devem constituir-se por um currículo significativo que "é aquele que faz sentido para os estudantes e que é relevante porque produz aprendizagens que causam impacto na vida de toda a cidade.” (MOLL, 2011, p.15). Os estudantes devem estar envolvidos em projetos interdisciplinares, focalizando os problemas comunitários e refletindo sobre possíveis intervenções para a melhoria do território.

Outro ponto-chave é a noção de cidade educadora. De acordo com Moll e Leclerc (2012), o conceito de cidade educadora surgiu em Barcelona, nos anos 90, e parte do entendimento de que todos os espaços da cidade são locais potenciais para a aprendizagem. Segundo as autoras, a cidade dispõe de inúmeras iniciativas educativas em espaços formais e informais, por isso, "quer-se promover estreita relação das crianças e adolescentes com a cidade, pela circulação por diversos espaços além da escola" (MOLL E LECLERC, 2012, p.35). Nesta perspectiva, o MEC expõe que a escola deve estar ligada à cidade, pois a educação nos preceitos da cidade educadora

Busca garantir às crianças, adolescentes e jovens o direito fundamental de circular pela cidade, apropriando-se dela, como condição de acesso as oportunidades, espaços e recursos existentes, como direito à ampliação contínua do repertório sociocultural e à expressão autônoma e crítica. (BRASIL, 2011, p.19).

A escola deve tecer relações com todos os atores que formam a cidade educadora, constituindo-se assim uma comunidade de aprendizagem:

Uma comunidade de aprendizagem, diz Rosa Maria Torres, é uma comunidade humana organizada que constrói um projeto educativo e cultural próprio para educar a si mesma, suas crianças, seus jovens e adultos, graças a um esforço endógeno, cooperativo e solidário, baseado em um diagnóstico não apenas de suas carências, mas, sobretudo, de suas forças, para superar essas carências. (TORRES, 1996 apud BRASIL, 2013 p.12).

O PME propõe reestruturação do currículo em formato de "Mandala", pois este "é o símbolo da totalidade (aparece em diversas culturas primitivas e modernas) e representa a integração entre o homem e a natureza" (BRASIL, 2009c, p.23). A Mandala de saberes é um 
símbolo que constrói diálogos e possibilidades de troca entre temas transversais, disciplinas, saberes e práticas cotidianas escolares e comunitárias, além de inúmeras mediações entre a escola e a comunidade. Portanto, a escola deve ser um local de troca entre os currículos escolares e a comunidade local.

No caderno Educação Integral, há a tentativa de superar o termo "contraturno" da legislação a partir da reformulação dos tempos e espaços escolares e da noção de que as atividades realizadas pela parte diversificada do currículo são apenas complementares, isto é, menos importantes do que as realizadas no turno tradicional. É apontada uma preocupação com a formação integral em seus âmbitos afetivos, éticos, sociais, culturais, políticos e cognitivos e não apenas com a ampliação da jornada escolar.

No Brasil, atualmente, são muitas as concepções de educação integral; esta proposta nasce em meio ao debate e apresenta uma visão capaz de levar à escola contemporânea uma ampliação das necessidades formativas do sujeito, contemplando as dimensões afetiva, ética, estética, social, cultural, política e cognitiva. Esta concepção de educação integral não se limita ao aumento do tempo e espaço nos projetos de educação, mas parte da idéia de que os estudantes são seres portadores de uma complexa experiência social e merecem atenção diferenciada porque são fruto de processos igualmente diferenciados. Compreende a educação como um desafio para escolas e comunidades e pretende dialogar com a complexidade de agentes sociais, territórios e saberes que envolvem as experiências comunitárias, buscando construir-se para além do espaço escolar. (BRASIL, 2009b, p.14. grifos nossos).

Já no documento Gestão Intersetorial, diante da questão: “o que crianças e adolescentes precisam aprender?", a resposta é formulada por meio de uma publicação da UNESCO (Dez fatores para uma educação de qualidade para todos no século XXI), e, em clara sintonia com uma concepção de educação para a empregabilidade, é respondido:

- Confiar em si mesmo e nos outros;

- Realizar um projeto;

- Dominar as capacidades necessárias para concluir um projeto;

- Relacionar-se com os demais de maneira saudável;

- Explicar sua própria vida e o mundo (MEC, 2009a, p.20).

\subsection{Gestão e financiamento do Programa Mais Educação}

Para sua operacionalização, o PME propõe um modelo de gestão intersetorial no intuito de tecer redes de proteção social aos educandos em situação de vulnerabilidade social. Para o MEC (2009a), a intersetorialidade é a articulação entre os ministérios e entre diferentes políticas 
públicas, na tentativa de superar a gestão pública setorializada. Nesta perspectiva, a intersetorialidade (p.25) "se materializa no cotidiano da gestão à medida que consegue criar consensos em torno de uma meta com a qual [...] todos possam comprometer-se". Nesse caso, as políticas públicas devem estar articuladas para a garantia da educação integral, vista pelo prisma de "proteger e educar". Segundo o MEC,

\begin{abstract}
Nesse duplo desafio - educação/proteção - no contexto de uma "Educação Integral em Tempo Integral", ampliam-se as possibilidades de atendimento, cabendo à escola assumir uma abrangência que, para uns, a desfigura e, para outros, a consolida como um espaço realmente democrático. Nesse sentido, a escola pública passa a incorporar um conjunto de responsabilidades que não eram vistas como tipicamente escolares, mas que, se não estiverem garantidas, podem inviabilizar o trabalho pedagógico. (BRASIL, 2009b, p.17).
\end{abstract}

Para a garantia da educação/proteção integral, o MEC propõe a articulação de "25 programas federais formulados pelos 6 (seis) ministérios participantes" (BRASIL, 2009a , p.28). Sendo eles:

- Ministério do Esporte - Esporte e Lazer, Segundo Tempo;

- Ministério da Cultura - Cineclube Escola, Cultura Viva, Casas de Patrimônio;

- Ministério da Ciência e Tecnologia - Casa Brasil Inclusão Digital, Centros Vocacionais Tecnológicos, Centros Museus da Ciência;

- Ministério do Desenvolvimento Social e Combate à Fome - Programa Atenção à Família (PAIF), Projovem Adolescente, Centro de Referência Especializado de Assistência Social (CREAS), Programa de Erradicação do Trabalho Infantil (PETI);

- Ministério do Meio Ambiente - Sala Verde, Munícipios Educadores Sustentáveis, Viveiros Educadores;

- Ministério da Educação - Sala de recursos Multifuncionais, Pro Info, Comissão Meio Ambiente e Qualidade de Vida, Educação e Direitos Humanos, Educação Inclusiva: direito à diversidade, Escola que protege juventude e meio ambiente, Escola Aberta, Educar na diversidade ${ }^{29}$.

Em 2014, articula-se também o Programa Escolas Interculturais de Fronteira (PEIF) do MEC, $\left(\right.$ FNDE, 2014) ${ }^{30}$. A ideia de proteger/educar coloca o PME como um programa de ação de políticas redistributivas de combate à pobreza, a partir de redes de proteção que se constroem por meio de ações intersetoriais, isto é, pela articulação de diferentes políticas públicas e de ações integradas, em que toda a sociedade tem responsabilidade pela educação.

\footnotetext{
${ }^{29} \mathrm{O}$ caderno Gestão Intersetorial (MEC, 2009, a) traz informações específicas sobre cada um dos programas citados.

${ }^{30}$ Consultar: http://portal.mec.gov.br/escola-de-fronteira/escola-de-fronteira.
} 
A articulação entre Educação, Assistência Social, Cultura e Esporte, dentre outras políticas públicas, poderá se constituir como uma importante intervenção para a proteção social, prevenção a situações de violação de direitos da criança e do adolescente, e, também, para melhoria do desempenho escolar e da permanência na escola, principalmente em territórios mais vulneráveis. (BRASIL, 2009b, p.25).

Nesta visão, as ações intersetoriais, além de promoverem a proteção social, melhoram o desempenho escolar e a permanência na escola; em outras palavras: elas também são ações eficazes para aumentar os índices de avaliação aferidos pelo IDEB. Os cadernos apontam, assim como a legislação, a centralidade do IDEB como referência para o PME. Todavia, também ressaltam que:

o aumento do tempo escolar necessário à Educação Integral que propomos não objetiva dar conta apenas dos problemas que os alunos enfrentam devido ao baixo desempenho nos diversos sistemas de avaliação, pois o que se pode constatar, em alguns casos, é que o aumento da jornada de trabalho escolar dos alunos em disciplinas específicas, como Matemática ou Língua Portuguesa, tem gerado processos de hiperescolarização, que não apresentam os resultados desejados. (BRASIL, 2009b, p.36).

$\mathrm{Na}$ estrutura administrativa do PME, destacam-se os Comitês Locais e Comitês Territoriais, além do Fórum Mais Educação. Segundo o MEC (BRASIL 2009, a), as instâncias administrativas estão organizadas em três dimensões: nacional, territorial e escolar.

O Fórum Mais Educação tem por incumbência instrumentalizar a gestão intersetorial e interministerial em âmbito nacional. Aos fóruns cabem fornecer subsídios para o planejamento das ações do PME, acompanhar sua implementação e avaliá-lo, além de promulgar a articulação institucional e cooperação técnica em um espaço composto por integrantes dos vários ministérios, secretarias federais, governos estaduais e municipais (BRASIL, 2009a). Em pesquisa realizada por Silva e Silva, aponta-se que "relatos dos gestores revelam que o Fórum foi inoperante e quase inexistente" (SILVA E SILVA, 2013, p.147).

O comitê local, por sua vez, está encarregado de mapear as oportunidades educativas dos territórios e

tem por objetivo integrar diferentes atores do território em que a escola está situada para formular e acompanhar o Plano de Ação Local de Educação Integral - plano que contempla as atividades escolhidas, as parcerias estabelecidas, o número de estudantes atendidos. Os territórios se constituem a partir da escola e abarcam o entorno no qual os estudantes vivem. Além disso, são perpassados pelo conjunto dos serviços, programas, projetos e equipamentos das políticas de educação, cultura, assistência social, esporte, educação ambiental, ciência e tecnologia e outras. $O$ conjunto de atores sociais presentes neste espaço também constituem [sic] o território (ONGs, 
associações comunitárias, clubes de mães, associações comerciais, entre outros). (BRASIL, 2015, p.19).

Para estabelecer parcerias nos territórios, um membro do corpo docente da unidade escolar é designado, sendo intitulado como professor comunitário. Esse professor não é financiado pelo governo federal, suas horas trabalhadas no programa são pagas pelo poder público ao qual está vinculado e ele deve cumprir carga de horária de 40 horas semanais na escola. De acordo com o MEC, professor comunitário deve ser preferencialmente um professor efetivo do corpo docente escolhido pela Unidade Executora. São suas atribuições: divulgar o programa; executar o planejamento das atividades; auxiliar os monitores; identificar parceiros locais; participar das reuniões do comitê local e das reuniões e formações realizadas pelas secretarias de apoio; planejar e realizar ações que propiciem vínculos entre escola e comunidade.

Os comitês territoriais têm por missão criar a articulação entre as secretarias municipais e estaduais, instituições acadêmicas e outros atores sociais no intuito de contribuir e propor ações de planejamento, implementação, acompanhamento e avaliação da política de educação integral em determinada região. Em documento da "Comissão de Educação, cultura de avaliação de políticas públicas", apresentado no Senado Federal, e com relação ao Programa Mais Educação em 2015, aponta-se a atuação positiva dos comitês regionais na manutenção e proposição de melhorias para o programa, de acordo com as especificidades da região onde foi implementado. Embora não tenham sido regulamentados por lei, foram consideradas pelos atores locais iniciativas importantes para a melhoria do PME em suas respectivas redes de ensino (BRASIL, 2015).

Os recursos do PME são destinados às escolas estaduais e municipais que aderirem ao PME e que possuam estudantes no ensino fundamental. Seu financiamento ocorre pelo Fundo Nacional de Desenvolvimento da educação (FNDE), do Programa Dinheiro Direto na Escola (PDDE). O repasse de verbas é feito por meio de conta bancária específica, aberta pelo FDNE, no banco e conta indicados no sistema PDDEweb. O depósito é feito em nome da Unidade Executora Própria (UEx), representativa da unidade escolar (BRASIL, 2014).

Segundo resolução do FNDE, “as escolas públicas com mais de cinquenta alunos matriculados no ensino fundamental, nas modalidades regular e especial, para serem beneficiadas com recursos do PDDE deverão, obrigatoriamente, constituir suas respectivas Unidades Executoras" (FNDE, 2008, n.p). Segundo Vera Peroni e Theresa Adrião (2007), o PDDE foi criado em 1995 com o nome de Programa de Manutenção e Desenvolvimento do Ensino Fundamental (PMDE), em 1998, sua denominação foi alterada para Programa Dinheiro 
Direto na Escola (PDDE). As autoras apontam que, desde 1997, os repasses financeiros do FNDE são condicionados pela abertura, por parte da unidade escolar, de uma UEx, isto é, entidades sem fins lucrativos com representantes da comunidade escolar.

Os recursos destinados via PDDE/educação integral são destinados para

Ressarcimento com as despesas de transporte e alimentação dos monitores responsáveis pelo desenvolvimento das atividades; Aquisição dos materiais pedagógicos necessários as atividades, conforme os kits sugeridos; Aquisição de outros materiais de consumo e/ou contratação de serviços necessários ao desenvolvimento das atividades de educação Integral (FNDE, 2013, p.23).

Portanto, os recursos destinados diretamente à unidade escolar a responsabiliza completamente pelo desenvolvimento do turno destinado às atividades do PME, tanto no que tange a aquisição de materiais pedagógicos e de apoio, quanto no que se refere ao pagamento de pessoal.

As atividades no contraturno escolar são realizadas por monitores, podendo estes ser pessoas da comunidade, artistas, aposentados, estudantes do ensino médio ou universitário. Os interessados assinam um termo de trabalho voluntário e recebem uma ajuda de custo de $R \$ 80$ reais (escola urbana) ou $\mathrm{R} \$ 120$ reais (escola rural) por turma atendida. Cada oficina ocorre uma vez por semana e tem duração de duas horas. Cada monitor pode ministrar até cinco oficinas na mesma escola, somando um total máximo por mês de $\mathrm{R} \$ 450$ reais (escola urbana), ou R \$ 600 reais (escola rural) (FNDE, 2014). Em 2016 (FNDE, 2006), aumentou-se a ajuda de custo para os oficineiros do macrocampo acompanhamento pedagógico, somando $\mathrm{R} \$ 160$ reais por mês por turma atendida (escola urbana), ou R \$ 240 reais/mês (escola rural).

O trabalho de monitoria deverá ser desempenhado, preferencialmente, por estudantes universitários de formação específica nas áreas de desenvolvimento das atividades ou pessoas da comunidade com habilidades apropriadas, como, por exemplo, instrutor de judô, mestre de capoeira, contador de histórias, agricultor para horta escolar, etc. Além disso, poderão desempenhar a função de monitoria, de acordo com suas competências, saberes e habilidades, estudantes da EJA e estudantes do ensino médio. Em 2009, foram produzidos três cadernos para subsidiar a implementação e execução do PME (FNDE, 2013, p.23).

Para o cálculo dos repasses de verbas destinadas às escolas, é levado em consideração o número de educandos inscritos no PME. Até 2015, os valores consistiam-se em repasses de 
custeio para contratação de serviços e compra de material, além de repasses de capital para a aquisição de bens ou materiais, de acordo com os kits ${ }^{31}$ sugeridos em cada macrocampo.

A tabela a seguir traz um esboço do repasse promulgado pelo CD/FNDE:

\begin{tabular}{|l|l|l|l|}
\hline $\begin{array}{l}\text { Número de } \\
\text { educandos }\end{array}$ & $\begin{array}{l}\text { Valor mensal do } \\
\text { Repasse em custeio } \\
\text { R\$ }\end{array}$ & $\begin{array}{l}\text { Valor mensal do } \\
\text { repasse em capital } \\
\text { R\$ }\end{array}$ & Total \\
\hline Até 500 & 3000 & 1000 & 4000 \\
\hline De 501 a 1000 & 6000 & 2000 & 8000 \\
\hline Mais de 1000 & 7000 & 2000 & 9000 \\
\hline
\end{tabular}

Tabela elaborada com bases nas informações na Resolução CD/FNDE n ${ }^{\circ}$ 14, de 9 de junho de 2014.

Em 2016, os repasses resumiam-se em R $\$ 10$ reais por mês por aluno atendido pelo PME. Os valores transferidos às UEx representativas das escolas beneficiárias seriam divididos em duas parcelas, sendo a primeira na proporção de $60 \%$ (sessenta por cento) e a segunda de $40 \%$ (quarenta por cento) (FNDE, 2016).

No que tange os recursos referentes à alimentação no PME, esses são garantidos pelo Programa Nacional de Alimentação Escolar (PNAE).

Segundo o MEC (BRASIL,2012), a adesão ao PME ocorre por meio de ação voluntária, do Estado ou Município que tenha assinado o Termo de Compromisso Todos pela Educação, além de comprovar a situação de regularidade de suas Entidades Executoras perante a União. As escolas selecionadas devem elaborar um "Plano de Atendimento", com as atividades que irão desenvolver e o número de educandos atendidos. Os Planos de Atendimento devem pautarse

De acordo com o Projeto Político Pedagógico das unidades escolares e desenvolvidos, por meio de atividades, dentro e fora do ambiente escolar, ampliando tempo, espaço e oportunidades educativas, na perspectiva da Educação Integral do Estudante (BRASIL, 2012, p.42).

Os critérios estabelecidos pelo MEC para o ingresso das escolas no PME, em 2008, eram: "ter assinado o Compromisso Todos pela Educação; todas as capitais dos estados brasileiros; cidades das regiões metropolitanas com mais de 200 mil habitantes; ter escolas

\footnotetext{
${ }^{31}$ Segundo documento do FNDE, “Os kits são compostos por materiais pedagógicos e de apoio sugeridos para o desenvolvimento de cada uma das atividades. Para cada uma delas, há uma sugestão de materiais que poderão ser adquiridos com o recurso do PDDE/Integral"' (FNDE, 2013).
} 
estaduais com IDEB ${ }^{32}$ abaixo de 2.9” (BRASIL, 2009b, p.14). Em 2011, os critérios para a adesão foram flexibilizados, integrando escolas que receberam o PDE/escola em 200933, escolas localizadas em locais de vulnerabilidade social e escolas em cidades com população igual e/ou superior a 18 mil habitantes (FNDE, 2011).

A partir de 2012, ocorre uma forte vinculação da adesão ao PME, não mais apenas com relação aos baixos índices do IDEB, mas também em escolas situadas em locais de vulnerabilidade social e com a maioria das famílias das crianças atendidas sendo beneficiária de algum programa social, principalmente o Bolsa Família. Dentre os critérios, destacamos:

- Escolas localizadas em municípios com índices de pobreza do campo (maior ou igual $25 \%$;

- escolas estaduais, municipais e/ou distritais que foram contempladas com o PDE/Escola e que possuam o IDEB abaixo ou igual a 4,2 nas séries iniciais e/ou 3,8 nas séries finais;

- escolas localizadas nos territórios prioritários do Plano Brasil Sem Miséria;

- escolas com índices igual ou superior a 50\% de estudantes participantes do Programa Bolsa Família (FNDE, 2012, p.7).

Em 2014, o PME estende-se para qualquer município do país, porém prevê atendimento prioritário para escolas com baixo IDEB e situadas em locais de vulnerabilidade social. Dentre os critérios, destacamos:

- Escolas estaduais, municipais e/ou distritais que foram contempladas com o PDE/Escola e que possuam o IDEB abaixo ou igual a 3,5 nos anos iniciais e/ou finais, IDEB anos iniciais < 4.6 e IDEB anos finais < 3.9;

- Escolas com índices igual ou superior a 50\% de estudantes participantes do Programa Bolsa Família;

- Municípios com 15\% ou mais da população "não alfabetizados";

- Municípios que apresentam 25\% ou mais de pobreza rural;

- Municípios com 30\% da população "rural";

- Municípios com assentamento de 100 famílias ou mais (FNDE, 2014, p.17).

Em relação aos estudantes prioritários, o documento expõe critérios relacionados ao rendimento escolar, à evasão e repetência, assim como a crianças em situação de risco social, conforme lê-se:

- Estudantes que apresentam defasagem idade/ano;

\footnotetext{
${ }^{32}$ Segundo o site do Inep "representa a iniciativa pioneira de reunir em um só indicador dois conceitos igualmente importantes para a qualidade da educação: fluxo escolar e médias de desempenho nas avaliações".

${ }^{33}$ Programa desenvolvido para auxiliar escolas com Ideb igual ou inferior a 4,4, nos anos iniciais, e 3,7 nos anos finais do ensino fundamental.
} 
- Estudantes das séries finais da $1^{\mathrm{a}}$ fase do ensino fundamental $\left(4^{\circ} \mathrm{e} / \mathrm{ou} 5^{\circ}\right.$ anos), onde existe maior saída espontânea de estudantes na transição para a $2^{a}$ fase;

- Estudantes das séries finais da $2^{\mathrm{a}}$ fase do ensino fundamental $\left(8^{\circ} \mathrm{e} / \mathrm{ou} 9^{\circ}\right.$ anos), onde existe um alto índice de abandono após a conclusão;

- Estudantes de anos/séries onde são detectados índices de evasão e/ou repetência;

- Estudantes beneficiários do Programa Bolsa Família (FNDE, 2014, p.18).

Portanto, foi por meio dos índices de evasão escolar, reprovação, vulnerabilidade social e qualidade de ensino mensurada por avaliações externas, além de dados populacionais, que o Ministério da Educação selecionou e definiu as escolas e zonas prioritárias de atendimento do Programa Mais Educação.

Em 2015, com a crise econômica e os cortes orçamentários do Governo Federal, o PME não abriu novas inscrições para adesão, houve atrasos nos repasses de verbas para as escolas, além da especulação da imprensa de que o PME poderia estar com os dias contados. Mediante avaliação negativa, feita pela Fundação Itaú e BM, de que o PME não trazia aumento nos índices das avaliações externas, em 2016, o critério prioritário para a adesão ao programa era de escolas com baixos índices no IDEB, como aponta o documento do ano:

I - A primeira fase priorizará as escolas cujos estudantes obtiveram baixo rendimento na Prova Brasil, conforme relação a ser publicada pela SEB/MEC e homologada pela secretaria de educação à qual cada escola se vincula (FNDE, 2016, n.p).

Podemos ver que houve uma convocação, a partir da relação publicada, para que as escolas com índices insatisfatórios no IDEB aderissem ao PME, que passaria a focalizar, em suas ações, o ensino de português e matemática para os testes.

\section{4 os reformadores e o Programa Novo Mais Educação}

Em 2015, a fundação Itaú, em parceria com o Banco Mundial, divulgou o Relatório de avaliação econômica e Estudos Qualitativos - O programa Mais Educação MEC. O documento faz uma avaliação do Programa Mais Educação Federal entre os anos de 2008 e 2011 e conclui que, durante sua primeira fase de implementação, não foram encontradas melhorias nos índices em português e matemática, aferidos pela Prova Brasil. Aponta-se que não houve variação nos resultados de evasão e nos resultados da avaliação de língua portuguesa, 
contudo, encontra-se uma leve queda no desempenho de matemática dos alunos participantes do Programa.

Para o documento em questão, os objetivos da educação integral nos países que adotam a política de educação integral em tempo integral são: "baixar as taxas de abandono, melhorar a aprendizagem do aluno e, em última análise, reduzir as desigualdades de renda." (FUNDAÇÃO ITAÚ, p.44). Em seus argumentos, a evasão escolar e os resultados em provas externas foram os tópicos escolhidos para a avaliação do PME, visto que são dados mensuráveis que dispõem de índices dos censos escolares e das avaliações.

A metodologia utilizada foi o "pareamento por escore de propensão", no qual são explorados os dados administrativos da expansão do PME, bem como informações do censo escolar e da prova Brasil. Foram avaliadas 600 escolas inscritas no programa, em todo o território nacional. Compararam-se os censos escolares e a progressão nos resultados da Prova Brasil, entre unidades participantes e não participantes, com situações socioeconômicas semelhantes, e concluiu-se que os impactos do PME são irrelevantes, ou até mesmo negativos, nos índices avaliados.

Para o documento, os impactos negativos maiores são na fase inicial de implementação e estão relacionados às mudanças de gestão que ocorrem na escola, afetando a todos os atores da instituição: professores, alunos e gestores. Em sua perspectiva, à medida que o programa se consolida, os resultados podem melhorar, sendo que os melhores índices tendem a estar nos municípios com maior Produto Interno Bruto (PIB).

Na visão da Fundação Itaú, os diferentes macrocampos possibilitam uma vasta gama de possibilidades a serem realizadas no contraturno escolar. Diante disso, a escolha das atividades também afeta os resultados. Aponta-se que as escolas que optaram por atividades de português, no macrocampo conhecimento pedagógico, esportes, cultura e lazer, tenderam a ter impactos negativos nos resultados, já matemática, educação ambiental e inclusão digital não pioraram os índices, mas também não obtiveram resultados significativos.

As limitações do estudo são postas sob a seguinte ótica: "Reconhecemos, entretanto, que as metas do Mais Educação são bastante mais amplas, e, assim, uma limitação desse estudo está no fato de que avaliamos somente as dimensões das habilidades cognitivas e do fluxo escolar" (FUNDAÇÃO ITAÚ, 2015, p.96). Apesar do reconhecimento, é evidente que o estudo, por si só, demonstra quais são seus entendimentos sobre a qualidade da educação: os índices das avaliações externas em português e matemática.

Em nossa visão, não é possível aferir o impacto de um programa amplo (com um leque de opções nas diversas áreas e linguagens do conhecimento) apenas pelos índices de 
desempenho em português e matemática. O estudo da Fundação Itaú, não é mais que uma análise de impacto real, apenas descreditando o PME a partir de um entendimento reduzido sobre a educação integral do indivíduo e a partir de um olhar quantitativo voltado apenas para a mensuração de resultados.

Segundo Evangelista e Shiroma, a implantação da gestão por resultados na educação busca uma nova governabilidade, baseada pelo gerencialismo. Nessa visão, há a construção de um senso comum para enraizar a "cultura dos resultados" que reflete as recomendações dos Bancos e instituições empresariais para a educação. Para as autoras, "essas avaliações “científicas", por métodos "científicos" que envoltos em números, parecem corresponder à objetividade e explicá-la, não discutem as condições objetivas dos resultados”, pois é “da essência das estratégias dos reformadores velar a materialidade" (EVANGELISTA E SHIROMA, 2011, p.144).

A “cultura dos resultados' é reflexo de uma concepção difundida pelos reformadores na qual os investimentos em educação só são justificados desde que sua eficácia possa ser quantificada e mensurada. Laval aponta que "a eficácia é sempre mensurável, deve estar relacionada a dispositivos, a métodos e técnicas inteiramente definidas, padronizadas e reprodutíveis (LAVAL, 2004, p.207). Os organismos internacionais, como o Banco Mundial e a OCDE, procuraram desenvolver ferramentas para a medição dos "rendimentos educacionais", o que levou assim, na opinião de Laval , a um verdadeiro "culto a eficácia". O autor esclarece que a "eficácia não tem evidência que se crê. Ela é uma construção social, fruto de opiniões, de ideologias e de relações de força." (LAVAL, 2004, p.210).

O Banco Mundial se tornou um especialista em econometria educativa e segundo Laval, suas conclusões numéricas são apresentadas como sinônimo de boa gestão, que previnem as desigualdades e os desperdícios, todavia, acarreta perversos significados, pois concentra-se de maneira obsessiva nos indicadores, sem se preocupar com o real significado do medido, tendendo a apresenta-lo como a verdade absoluta de um todo, logo, não levando em consideração que "o real medido, tende então a ser sempre parte da realidade que se pode medir e se quer e acredita poder modificar “ (LAVAL, 2004, p.213). Essa racionalização quantitativa, típica das sociedades neoliberais, leva a fetichização do número, onde a cifra é transformada em fetiche e há uma constante fabricação quantitativa de dados sem a preocupação de seus significados reais. (DARDOT E LAVAL, 2016)

Freitas, em comentário aos resultados do documento da Fundação Itaú, argumenta de maneira lúcida: 
No Brasil, com a chegada da lógica dos reformadores, tudo vira uma questão de aprender português e matemática. Resumem a escola a isso, quando interessa. Nesta ótica, a melhoria da escola se mede, portanto, pelo aumento da média dos alunos nestas disciplinas. É tanta devoção às médias, que se alguém mostrar que há um aumento das médias nestas disciplinas quando a lua é cheia, proporão ensinar apenas no período de lua cheia. (FREITAS, 2015, n.p.)

No mesmo dia da divulgação da publicação da Fundação Itaú, o ex-ministro da educação, Aluízio Mercadante, em nota, comprometeu-se em ajustar o Programa Mais Educação. As modificações prometidas se concretizaram por meio da resolução $\mathrm{n}^{\circ} 2$ do FNDE, de 14 de abril de 2016, que estabeleceu as seguintes diretrizes: a) atender prioritariamente os alunos com problemas de alfabetização; b) atender prioritariamente estudantes com baixo rendimento na prova Brasil; c) atender posteriormente escolas que fizeram sua inscrição em 2014; d) aumentar a carga do macrocampo acompanhamento pedagógico; e) aumentar a ajuda de custo dos monitores do campo acompanhamento pedagógico; f) aumentar a ajuda de custo dos monitores das áreas rurais (FNDE, 2016). Portanto, atendem-se prioritariamente as escolas com baixos índices nas avaliações, aumenta-se o macrocampo acompanhamento pedagógico, que propõe reforço escolar nas disciplinas tradicionais como português e matemática, e diminui-se a parte diversificada do currículo.

A resolução em questão foi resposta imediata às críticas ao PME e foi também uma busca pela adequação ao consenso dos reformadores neoliberais sobre a qualidade da educação, hoje difundida nas políticas públicas em educação: melhoria dos índices em avaliações externas em nível nacional e internacional.

O Programa Novo Mais Educação foi instituído pela portaria $n^{0} 1.144$, de 10 de outubro de 2016, e determina a ampliação progressiva do tempo de permanência na escola com a ênfase central no aprendizado de português e matemática. Suas atividades foram iniciadas a partir de 2017. No texto da lei, são objetivos do programa:

I - alfabetização, ampliação do letramento e melhoria do desempenho em língua portuguesa e matemática das crianças e dos adolescentes, por meio de acompanhamento pedagógico específico;

II - redução do abandono, da reprovação, da distorção idade/ano, mediante a implementação de ações pedagógicas para melhoria do rendimento e desempenho escolar;

III - melhoria dos resultados de aprendizagem do ensino fundamental, nos anos iniciais e finais; e

IV - ampliação do período de permanência dos alunos na escola (BRASIL, 2016, n.p). 
A carga horária no contraturno escolar é de cinco ou quinze horas semanais, de acordo com a opção da escola no ato de inscrição. As atividades a serem desenvolvidas pelo novo programa são: obrigatoriamente acompanhamento pedagógico de português e matemática e optativamente atividades nos campos de artes, cultura, esporte e lazer. As escolas que optarem pela jornada de cinco horas realizarão duas atividades de acompanhamento pedagógico, obrigatoriamente, uma de português e outra de matemática, com duas horas e meia de duração cada, por semana. Portanto, não terão acesso à parte diversificada do currículo, apenas ao acompanhamento pedagógico.

O Documento Orientador - adesão, versão I - aponta que as escolas, com 15 horas de atividades por semana, realizarão duas atividades de acompanhamento pedagógico, obrigatoriamente português e matemática, com quatro horas de duração cada, e outras três atividades de escolha da escola, dentro dos campos mencionados. Isso faz com que oito horas por semana sejam destinadas a português e matemática e sete horas a outras atividades.

A execução do PNME é desenvolvida pelos seguintes atores: Articulador da Escola, Mediador da Aprendizagem e Facilitador. O Articulador da Escola será responsável por coordenar as atividades na escola, deverá ser um professor ou coordenador pedagógico com carga mínima de 20 horas na unidade escolar; O Mediador da Aprendizagem, será o responsável pelas atividades de acompanhamento pedagógico em português e matemática; e, por último, o Facilitador será o responsável pelas atividades escolhidas pela escola nos campos diversificados.

O termo facilitador emprega uma conotação de que seu trabalho é "facilitar" o sucesso das áreas prioritárias: português e matemática. Sua figura, nessa concepção, é um mero apêndice. As atividades nos campos da cultura, artes, esporte e lazer são chamadas de atividades complementares e, portanto, não são protagonistas nesta nova visão.

A publicação "Perguntas Frequentes - Programa Novo Mais Educação" deixa claro que o primeiro programa não existe mais, foi substituído. Todavia, a centralidade do IDEB para a escolha das escolas prioritárias, as avaliações externas como orientadoras do projeto e a expansão da jornada escolar pelo voluntariado permanecem. Os valores pagos aos mediadores e facilitadores são expostos na publicação:

I - R\$ 150,00 (cento e cinquenta reais) por mês, por turma de acompanhamento pedagógico, para escolas urbanas que implementarem carga horária complementar de 15 (quinze) horas;

II - R \$ 80,00 (oitenta reais) por mês, por turma das atividades de livre escolha da escola, para escolas urbanas que implementarem carga horária complementar de 15 (quinze) horas; 
III - R\$ 80,00 (oitenta reais) por mês, por turma de acompanhamento pedagógico, para escolas urbanas que implementarem carga horária complementar de 5 (cinco) horas; [...]

VI - Para as escolas rurais o valor do ressarcimento por turma será $50 \%$ (cinquenta por cento) maior do que o definido para as escolas urbanas (BRASIL, 2016, n.p).

A noção de que a comunidade deve se responsabilizar pela oferta do aumento da jornada, desresponsabilizando o Estado na ampliação dos espaços, também é colocada pelo PNME. Embora não detalhe como as parcerias escola/comunidade devam acontecer, o documento aponta que se deve "mobilizar e estimular a comunidade local para a oferta de espaços, buscando sua participação complementar em atividades e outras formas de apoio que contribuam para o alcance das finalidades do Programa" (BRASIL, 2016).

Em nossa visão, o PNME não é uma proposta de educação integral, nem mesmo de educação integrada. É um programa de reforço escolar que tem por objetivo central responder às críticas dos reformadores da educação perante os baixos desempenhos do Brasil nas avaliações nacionais e internacionais. É, pois, uma ação que não discute nenhum projeto de formação ou de perspectiva para as crianças e jovens das classes desfavorecidas, além de um treinamento para a avaliações em larga escala.

\subsection{Reflexões finais e conclusões}

Os governos petistas propuseram uma política de conciliação e abertura aos interesses neoliberais. Seus avanços, nas áreas sociais, na criação de empregos e na geração de renda são inegáveis, todavia, não houve ruptura com os interesses neoliberais e sim uma política de conciliação. O PME trouxe, em sua trajetória, as características contraditórias que permeavam o programa de governo em vigor.

A formulação do Compromisso de Metas Todos pela Educação e do PDE são casos emblemáticos nos quais todas as propostas e recomendações de um grupo ligado ao empresariado brasileiro, no caso o TPE, são incorporadas como políticas públicas de governo. O PME, como uma das ações do PDE, traz, em sua operação, entendimentos e expectativas específicas sobre a implementação de uma política de educação integral e ampliação da jornada em todo o Brasil.

O PME apresentou, desde sua formulação inicial, todas contradições de uma política pública em um Estado capitalista. Em nossa visão, os documentos do PME demonstram que os 
vários atores sociais (educadores, legisladores e associações da sociedade civil), envolvidos na elaboração de um modelo de educação integral/em tempo integral, travaram uma disputa que, embora pacífica e consensual, resultou no PME. Na formulação dos documentos que nortearam a proposta, houve intensa participação/influência de educadores e universidades públicas, assim como de Organizações da Sociedade Civil ligadas a grupos do empresariado, como CENPEC e o Cidade Aprendiz. O resultado foi uma tentativa de conciliação entre ideias e perspectivas educacionais distintas e até opostas.

Ao mesmo tempo em que o programa ousou propor uma educação integral em tempo integral em escala nacional- uma reinvindicação de movimentos de pais, professores e por educação- a proposta entregue, incorporou muitas das recomendações dos reformadores neoliberais da educação.

No campo das ideias pedagógicas o PME se comprometeu não apenas com aumento da jornada escolar, mas com uma proposta real de educação integral. As atividades realizadas no contraturno em diversas áreas do conhecimento- esportes, lazer, artes, educação ambiental, artesanato- tinham como intuito combater a hipervalorização das disciplinas tradicionais do currículo, abrindo possibilidades para que outras linguagens estranhas ao universo escolar fossem ensinadas. Havia o desejo de novas experiências educativas que privilegiassem não apenas aspectos cognitivos, mas também sociais, afetivos, estéticos, políticos e culturais (BRASIL,2009b). Uma proposta que objetivou em seus documentos, entregar às classes desfavorecidas uma educação exclusiva das elites: aulas de dança, teatro, música, esportes diversos, para elencar algumas das possibilidades.

Todavia, em um aceno as concepções pedagógicas difundidas pelos organismos internacionais, no caderno gestão intersetorial, os objetivos da educação integral são reduzidos aos seguintes termos retirados da publicação da UNESCO "o que as crianças devem aprender no século XXI" : Confiar em si mesmo e nos outros; Realizar um projeto; Dominar as capacidades necessárias para concluir um projeto; Relacionar-se com os demais de maneira saudável; Explicar sua própria vida e o mundo (BRASIL, 2009b). Proposições em total consonância com as pedagogias do "aprender a aprender" amplamente difundidas a partir do relatório Jaques Delors "Educação um Tesouro Descobrir"

Na visão de autores como Duarte (2000) e Laval (2004) as pedagogias do "aprender a aprender" tem como finalidade implícita, integrar as camadas populares na lógica mercantil. Essa integração seria operada por meio de um ensino de competências mínimas para o mercado de trabalho, relegando à educação um papel utilitarista e não de formação integral. Laval, em 
análise a essas concepções, nos aponta, que para os reformadores, a qualidade dos conhecimentos adquiridos não importa, sendo alguns considerados inúteis e um estorvo. $\mathrm{O}$ essencial é que seja ensinado o que será útil para o trabalhador: Criatividade, desembaraço, trabalho em equipe e manejo dos códigos de base (LAVAL, 2004). Portanto, as pedagogias do “aprender a aprender", contemplam uma visão oposta à formação integral para a integralidade do ser e à produção e construção de conhecimentos tendo como partida os saberes comunitários. O PME tentou conciliar todas essas perspectivas em seus textos oficias.

Portanto, a concepção de educação trazida pelo PME não é consenso. Em alguns documentos, a formação é vista dentro de diferentes linguagens do conhecimento (os macrocampos) para propiciar aos estudantes uma formação ampla em seus diferentes aspectos como indivíduos, a partir da diversidade e dos saberes da comunidade alinhados aos saberes da escola. Enquanto, em outras publicações, o discurso alinha-se às propostas de Educação Para Toda a Vida e do "Aprender a aprender", em que o foco central é a aquisição de competências socioemocionais para a adaptação ao capitalismo e boa convivência mediante as diferenças para conformação do indivíduo em seu papel social ocupado na sociedade

Os documentos e a legislação também nos apontam que uma das justificativas para a implementação de um programa de educação integral nas escolas públicas em escala nacional, seria a proteção social das crianças e adolescentes pobres e em situação de vulnerabilidade. Embora o objetivo seja imprescindível para a formação de sujeitos de direito, não pode ser enxergado como educação compensatória ou como a razão de ser de um programa de educação integral. Ou seja, o que Freitas e Galter (2009) denominaram educação integrada, isto é, quando as questões de cunho assistencial se sobrepõem as de cunho educativo.

O PME, propôs um “duplo desafio" educação/proteção a partir de ações intersetoriais com outros ministérios, secretarias e órgãos do poder público. O objetivo era a fomentação de redes de proteção, sendo a escola seu núcleo central. Embora o programa tentasse se afastar da noção de educação integrada ao buscar múltiplos parceiros para a proteção das crianças e adolescentes em situação de vulnerabilidade social, não deixando a função assistencial exclusivamente como responsabilidade da escola, os critérios de seleção das escolas prioritárias para serem contempladas nos levantam algumas questões.

Como nos apontou Cavaliere, ao priorizar escolas com alunos contemplados pelo programa Bolsa Família ${ }^{34}$, a educação integral não é entendida como um direito, mas uma ação

\footnotetext{
${ }^{34}$ No ano de sua criação o PME prioriza escolas com pelo 50\% de estudantes participantes do programa Bolsa Família. Esses critérios serão flexibilizados com o decorrer dos anos como mostramos no capítulo V, todavia a
} 
setorizada de combate à pobreza (CAVALIERE, 2009). Na visão de Chauí, a noção de direito é diferente da noção de carência e interesse, pois o direito "não é particular e específico, mas geral e universal, seja porque é valido para todos os indivíduos, grupos e classes, seja porque é universalmente reconhecido por todos" (CHAUÍ, 2012 p.150). Portanto, ao focar a educação integral para os mais pobres sua noção como um direito de todas as crianças é afastada, o programa se aproxima da noção de educação integrada e é colocado em sintonia com as recomendações do Banco Mundial onde a necessidade de educação é entendida para o alívio da pobreza no intuito de inserir os indivíduos na economia de mercado e anestesiar as tensões sociais produzidas por uma sociedade dividida em classes.

Nesta perspectiva, a permanência na escola é compreendida como alívio à pobreza e contenção dos problemas econômicos e sociais que as camadas desfavorecidas enfrentam em seu dia a dia. Logo, a educação é entendida como remédio contra o aumento da criminalidade, ideia de "escolas cheias, cadeias vazias" que, na visão de Patto, trata-se do "discurso que atribui a escola a missão social de prevenção da criminalidade, não pelo ensino e pelo desenvolvimento de suas capacidades, mas como espaço de permanência para tirar os jovens da rua" (PATTO, 2006, p.265).

Concordamos com a análise de Silva e Silva ao problematizar as concepções de educação que têm como referência as Cidades Educadoras. Para os autores, os projetos de educação de tempo integral, baseados nos conceitos de "cidades educadoras" e "territórios educativos", reproduzem "nas escolas todos os problemas urbanísticos das cidades brasileiras [...]. Apelar para oferta de espaços educativos através das redes da sociedade civil pode ser sinônimo de espaço precário para uma educação precária” (SILVA E SILVA, 2014 p.95). Em nossa visão, propor trilhas educativas a partir da visão de cidades educadoras poderia partir da reflexão da tomada de consciência em relação às desigualdades sociais e econômicas da cidade, porém, o PME, ao propor visitas a "parques, ateliês, livrarias, bibliotecas, teatros, oficinas", distancia-se da realidade das comunidades na maioria dos contextos urbanos periféricos, marcados pela ausência de equipamentos culturais e pela dificuldade de deslocamento até o centro, onde estão localizados.

Segundo Silva e Silva (2014), ao propor uma visão sistêmica, advinda do PDE, o PME fundamenta-se por uma gestão gerencial e neotecnicista. A descentralização administrativa, financeira e operacional é acompanhada por ações centralizadas pelos critérios avaliativos do

prioridade do programa para escolas com crianças em situação de vulnerabilidade social esteve presente em todos os anos de existência do programa. 
IDEB e ao condicionamento de recursos - a assinatura do Plano de Metas Todos pela Educação. A visão sistêmica caracteriza-se por um modelo de gestão gerencial empresarial pautado na meritocracia e em processos de gerenciamento da força de trabalho na escola para o encalce dos índices das avaliações externas. Para Silva e Silva, esta foi a principal contribuição do TPE ao PME.

O modelo de gestão do PME conclama ações integradas e um regime de colaboração entre escola e sociedade para a busca de melhorias na qualidade do ensino. Como aponta Cavaliere (2014), a partir do PNE (2001-2014), consolidou-se uma concepção de que as atividades oferecidas pelo aumento da jornada escolar podem ser oferecidas por outras instâncias, além da escola, dentro ou fora de suas dependências e por agentes voluntários. Segundo publicação do CENPEC e da Fundação Itaú (2011), essa compreensão estabelece uma mudança de paradigma em que a escola rompe seu isolamento, abrindo-se para novas oportunidades de aprendizagem, por meio de ações desenvolvidas pela comunidade e pelas organizações sociais. O documento também advoga que esse é um modelo que possibilita otimizar recursos, porém é insuficiente para a garantia da universalização do tempo integral.

Trata-se de uma maneira de maior inserção do chamado terceiro setor na formação dos estudantes, além da otimização de recursos públicos. Nesta perspectiva, a ampliação da jornada deve acorrer pela prestação de serviços de ONGS, de Associações da Sociedade Civil ou pelo voluntariado, caso do PME. Em nosso entendimento, trata-se de uma visão privatista de educação. Desvincula-se assim a formação da escola e a entrega à concorrência das forças de mercado por meio de prestação de serviços realizada pela iniciativa privada. A educação é então enxergada como mercadoria e os estudantes são os clientes.

A ação do voluntariado para a melhoria da qualidade da educação é uma das bandeiras levantadas pelos reformadores neoliberais. A comunidade é convocada para trabalhar pela melhoria da qualidade da educação a partir de um discurso de "conscientização" da importância do papel da educação. Para Gentili, o trabalho voluntário sob a insígnia da responsabilidade social barateia os custos com contratação de pessoal e desmonta os vínculos empregatícios onerosos. Nesta visão, "pactua-se a privatização, direta ou indireta, descoberta ou encoberta [...] pela flexibilização e desregulação das relações laborais no setor educacional" (GENTILI, 2002, p.66).

Diferentemente dos CIEPS e do CECR, na medida em que não há perspectiva de ampliação do espaço físico da escola para abrigar o segundo tempo, podemos compreender que há a racionalização dos recursos e a transferência dos gastos para a sociedade civil. Essa perspectiva fica clara quando Moll relata que: 
A utilização dos espaços externos supre a falta de infraestrutura das escolas para ampliarem seus turnos. Nenhuma escola construída como "escola de turno", com espaços delimitados para determinado número de estudantes para a manhã e para a tarde, e às vezes para os três turnos diários, "transforma-se de um dia para o outro, em escola de jornada ampliada, em escola que inclui várias refeições diárias, em escola que acompanha, qualifica e diversifica a experiência formativa de seus estudantes. O Programa Mais Educação colabora no processo de uma agenda escolar cotidiana para a efetiva consolidação da educação integral em tempo integral. (MOLL 2011, p.138).

Portanto, podemos interpretar essa aproximação escola/comunidade como desresponsabilização do Estado com a educação em prol de um fortalecimento das alianças público-privadas. Essa concepção de flexibilização dos espaços, com apoio da sociedade civil, transmite para terceiros a responsabilidade pela ampliação da jornada.

O PME nasceu como uma estratégia do PDE e, assim, passa a ter, como objetivo central, melhorias no IDEB, isto é, um índice que é construído primordialmente por avaliações externas em português e matemática, fluxo de matrícula e evasão escolar. Trata-se de uma contradição diante de outras propostas do projeto: como as atividades dos diferentes macrocampos, a inserção dos saberes comunitários na escola e a construção de canais de diálogos entre as várias instâncias responsáveis pelo projeto, como o fórum Mais Educação e os comitês locais e territoriais.

A centralidade no IDEB é o "calcanhar de Aquiles" do PME, pois invalida a promessa de educação integral e faz do tempo integral na escola uma via de aferição de resultados em avaliações externas, enquanto a parte diversificada do currículo é enxergada como "atividades complementares" ou "mata tempo". Nessa perspectiva, alinha-se a propostas pautadas na busca da eficácia dos reformadores. Há maior participação nos serviços prestados, porém também maior controle aferido por avaliações externas em que a comunidade é responsabilizada pelos resultados obtidos.

Portanto, ao responsabilizar a sociedade pelo aumento da jornada em vez de investir na construção e expansão dos equipamentos; ao apelar para o trabalho voluntário e não para a contratação de pessoal; e ao avaliar/reduzir o projeto por/a índices de avaliações externas, dialoga de maneira direta com a concepção de qualidade da educação difundida pelos neoliberais que objetivam resultados em índices mediante a responsabilidade/responsabilização dos atores locais e baixos custos

As ações do PME, tendo como finalidade última, o aumento dos índices do IDEB, contradizem algumas de suas propostas centrais, como a reformulação do currículo, a quebra 
das barreiras entre o currículo tradicional e as atividades diversificadas, o combate a hipervalorização das disciplinas tradicionais e a valorização dos saberes comunitários na escola. Em nosso entendimento, é uma contradição gigantesca, pois coloca um programa rico em possibilidades educativas a serviço de provas externas que aferem índices de português e matemática. Portanto, a eficácia do programa seria definida e comprovada caso aumentasse os índices do IDEB das escolas participantes.

Segundo Laval, a lógica da eficácia, como sinônimo dos resultados em índices padronizados em avaliações externas, é uma das recomendações dos organismos internacionais para a medição dos "rendimentos dos investimentos educativos". A lógica econômica é o que determina o sentido de eficácia. Embora, aparentem técnicas neutras e científicas de controle do cumprimento dos objetivos para o alcance de excelência já definidos por toda a sociedade, as avaliações como medida de eficácia, trazem problemas 'na medida em que reconhecem apenas o "código da economia" que compara custos e benefícios" (LAVAL,2004, p.214).

Algo que, em outro texto, Laval e Dardot, definem como a fetichização do número, o que conduz as políticas públicas a tornaram-se "fábricas de resultados", isto é, se concentram obsessivamente nos indicadores, e não nos sentidos reais de suas propostas. (DARDOT E LAVAL, 2016). Ainda na perspectiva de Laval, a avaliação "da forma com que foi concebida não leva muito frequentemente à realidade do ato educativo em toda sua complexidade e tende a medir apenas uma ficção" (LAVAL, 2004, p.214). Ficção é o termo correto para presumir que um índice de desempenho em português e matemática, fluxo de matricula e evasão escolar como o IDEB, poderia servir como critério de efetividade e medida de avaliação de um programa de educação integral como o Mais Educação.

Em 2015 a publicação conjunta do Banco Mundial e da Fundação Itaú "Relatório de avaliação econômica e Estudos Qualitativos - O programa Mais Educação MEC”, considerou o PME ineficaz pois não aumentou os índices de português e matemática aferidos pelo IDEB. Em 2016 com o impeachment da presidente Dilma Rouseff e a troca dos quadros do MEC, o programa foi extinto e rebatizado de Programa Novo Mais Educação. Este último, uma proposta de reforço escolar, onde o aumento do tempo na escola é utilizado, prioritariamente, para o ensino de português e matemática, assim, uma total reestruturação do projeto para atingir a eficácia.

Ao se comprovar ineficaz pela lógica dos experts em educação, nada mais restava ao PME que uma profunda reestruturação que impedisse a despesa pública de ser desperdiçada. Mediante as críticas feitas, o governo petista tentou ajustar o programa seguindo sua lógica de conciliação deixando-o mais palatável aos reformadores. Todavia, com a mudança de governo 
e dos quadros de gestão do MEC o programa é extinto, e em seu lugar, o PNME alinha-se completamente à lógica da educação para os resultados.

Com a mudança de governo no país, em setembro de 2016, assistimos a uma aproximação mais abrupta aos preceitos dos reformadores. As propostas recentes de ajuste estrutural, redução de benefícios sociais e aproximação com os setores conservadores orientam as novas ações políticas e, consequentemente, a direção tomada pelas políticas públicas como "Estado em ação". Configura-se então como uma concepção de Estado que partilha integralmente dos pressupostos dos reformadores neoliberais da educação: educação eficiente e produtiva, voltada para a divisão do trabalho e avaliada por índices aferidos em avaliações externas. Não há espaço para a integralidade do ser humano nesta concepção. Diante do cenário apresentado, uma das primeiras medidas do MEC foi a substituição do PME pelo PNME.

A reformulação instantânea do PME, perante as críticas do empresariado, demonstra como os reformadores neoliberais da educação estão inseridos capilarmente nas formulações e decisões das políticas públicas em Educação. Cada vez mais o campo educacional alinha-se ao projeto de reestruturação das forças produtivas do capital, que encontram na escola um lugar estratégico para a formação de um trabalhador que atenda a suas demandas.

O PME, apesar das críticas, fez com que as unidades participantes vivenciassem experiências que romperam com um modelo anterior de escola, foram tentativas e esforços para ofertar uma educação integral por meio do tempo integral, do qual as classes desfavorecidas nunca tiveram acesso. Uma avaliação real do impacto do programa na escola não pode ser baseada unicamente na estatística. As formas de apropriação das práticas cotidianas da escola são desconhecidas, a escola é muitas vezes o único lugar de construção de cidadania, e, em alguns locais do Brasil, a ampliação da jornada escolar, com certeza, gerou novas experiências de escolarização que não são passíveis de ser mensuradas em índices e censos escolares. A substituição do PME, sem a escuta e a avaliação daqueles que o vivenciaram, mostra os horizontes que as políticas públicas em educação, na atual conjuntura política, vislumbram: uma educação não democrática, em que os atores da escola pública são chamados apenas para “consensuar" diretrizes, já pré-estabelecidas por "especialistas" alinhados com uma visão produtiva, mercantilizada e de "resultados". Resultados para quem e a interesse de quem? Eis a questão. 


\section{REFERÊNCIAS BIBLIOGRÁFICAS}

ADRIÃO Theresa e PERONI, Vera. Implicações do Programa Dinheiro Direto na Escola para a gestão pública. Educação e Sociedade, vol.28, n98, p.253-267, 2007.

ARAÚJO, Sueldes de \& CASTRO, Alda Maria Duarte Araújo. Gestão educativa gerencial: superação do modelo burocrático? Revista: Ensaio: avaliação de políticas públicas educacionais, v.19 nº 70 , p.81-106, 2011.

ALTMANN, Helena. Influências do Banco Mundial no projeto educacional brasileiro. Educação e Pesquisa, vol.28, n¹, p.77-89, 2002.

ASSOCIAÇÃO CIDADE ESCOLA APRENDIZ. Bairro-Escola passo a passo. São Paulo: Cyty gráfica e Editora Ltda 2007.

BANCO MUNDIAL. Relatório sobre o desenvolvimento mundial, Washington D.C, 1990 Disponível em:http://documents.worldbank.org/curated/pt/188701468322757498/Relatorio-sobre-odesenvolvimento-mundial-1990-a-pobreza. Acesso em 20 de julho de 2017.

BANCO MUNDIAL. Prioridades y estratégias para la educación. Estudio sectorial del Banco Mundial. Depart de educación y políticas sociales, 1995. Disponível em : http://documents.worldbank.org/curated/en/715681468329483128/pdf/14948010spanish.pdf. Acesso em 20 de Julho de 2017.

BANCO MUNDIAL Relatório sobre o desenvolvimento mundial. Washington: Banco Mundial, 2000-2001, Washington, DC, 2000. Disponível em http://documents.worldbank.org/curated/pt/927161468164645652/pdf/226840PORTUGUE1z a20001200101PUBLIC1.pdf. Acesso em 29 de julho de 2017.

BANCO MUNDIAL. Achieving world class education in Brazil the next agenda, Washington, DC, 2010. Disponível em:

http://siteresources. worldbank.org/BRAZILINPOREXTN/Resources/3817166-

1293020543041/FReport_Achieving_World_Class_Education_Brazil_Dec2010.pdf.

Acesso em 17 de julho de 2017.

BANCO MUNIDAL Aprendizagem para todos: Estratégia 2020 para a Educação do Grupo Banco Mundial. Resumo executivo. Washington, DC: Banco Mundial, 2011.Disponível em http://siteresources.worldbank.org/EDUCATION/Resources/ESSU/463292-

1306181142935/Portguese_Exec_Summary_ESS2020_FINAL.pdf. Acesso 17 de julho de 2017.

BANCO MUNDIAL. Relatório Anual. Um mundo sem pobreza -erradicar a pobreza extrema e promover a prosperidade compartilhada. Washington, DC 2013. Disponível https://openknowledge.worldbank.org/bitstream/handle/10986/16091/9780821399422PT.pdf?sequence=5. Acesso em 20 de Julho de 2017.

BOITO, Armando Jr. O lulismo é um tipo de bonapartismo? Uma crítica às teses de André Singer. Crítica Marxista, n³7, p. 171-181, 2013.

BOMENY, Helena. A escola no Brasil de Darcy Ribeiro. Em Aberto. Instituto Nacional de Estudos e Pesquisas Educacionais Anísio Teixeira. Brasília, v. 22 n80, p. 109-120, 2009. 
BOTO, Carlota. Nacionalidade, escola e voto: a Liga Nacionalista de São Paulo. Em Perspectivas: ciências sociais. Araraquara: Unesp, 17-18, 1994-1995, pp. 145- 163, 1994/1995.

BOURDIEU, Pierre (org.). A miséria do mundo. Petrópolis-RJ: Vozes, 1997.

BOURDIEU, Pierre. A escola conservadora: as desigualdades frente à escola e à cultura. Em Nogueira, Maria. A.; Catani, Afrânio M. (Orgs.). Pierre Bourdieu: escritos de educação. Petrópolis: Vozes, 1998

BOURDIEU, Pierre. Escritos de Educação. Petrópolis-RJ: Vozes, 2002.

BRASIL. Constituição. Constituição da República Federativa do Brasil. Brasília, DF: Senado Federal, 1988.

BRASIL. Lei no 8.069, de 13 de julho de 1990. Estatuto da criança e do adolescente. Diário Oficial da União, Brasília, DF, 16 jul. 1990.

BRASIL. Plano Diretor de reforma do Aparelho. Brasília, DF: MARE, 1995.

BRASIL. Lei $\mathbf{n}^{\circ} 9.324$ de 20 de dezembro de 1996, estabelece as Diretrizes e Bases da educação nacional. Diário Oficial da União. Brasília, DF, 1996.

BRASIL. Lei n⿳ 10.172, de 9 de janeiro de 2001. Plano Nacional de Educação. Brasília. DF,2001.

BRASIL. Lei n 11.494, de 20 de junho de 2007. Diário oficial da União, Brasília, DF, 2007ª .

BRASIL. Portaria normativa interministerial $n^{\circ} .17$, de 24 de abril de 2007. Diário Oficial da União. Brasília, DF, 2007b

BRASIL. Decreto $n^{\circ}$ 6.094 de 24 de Abril de 2007. Plano de Metas Compromisso Todos pela Educação. Brasília, DF. 2007c

BRASIL. Rede de Saberes Mais Educação: pressupostos para projetos pedagógicos. Brasília, DF. MEC/SECAD, 2009ª .

BRASIL. Educação Integral: texto referência para o debate nacional. Brasília, DF. MEC/SECAD, 2009b.

BRASIL. Gestão intersetorial no território. Brasília, DF. MEC/SECAD, 2009c

BRASIL. Decreto $\mathbf{n}^{\mathbf{0}} \mathbf{7 . 0 8 3}$, de 27 de janeiro de 2010. Regulamenta o Programa Mais Educação. Diário Oficial da União, Brasília, DF, 2010

BRASIL. Programa Mais Educação Passo-a-Passo. Brasília, DF MEC/SECAD, 2011.

BRASIL. Caminhos para elaborar uma proposta de Educação Integral de Jornada Ampliada. Brasília, DF. MEC/SECAD, 2013. 
BRASIL. Lei $\mathbf{n}^{\circ} \mathbf{1 3 . 0 0 5}$ de 25 de junho de 2014. Plano Nacional de Educação (PNE). Brasília, DF, 2014

BRASIL. portaria n⿳ 1.144 de 10 de outubro de 2016. Diário Oficial da União. Brasília, DF, 2016a.

BRASIL. Programa Novo Mais Educação. Documento orientador- Adesão- Versão I. Brasília, DF; MEC/SEC, 2016b.

BRASIL. (2016d) Perguntas Frequentes - Programa Novo Mais Educação. Página do MEC, acessado em 15 de julho de 2017, 2016c de http://portal.mec.gov.br/index.

CAVALARI, Rosa Maria Feiteiro. Integralismo: ideologia e organização de um partido de massa no Brasil (1932-1937), Bauru, São Paulo: EDUSC, 1999.

CARVALHO, Marta Maria Chagas de. A escola e a república. São Paulo, ed. Brasiliense, col. Tudo é história, 1989.

CARVALHO, Marta Maria Chagas de. Molde nacional e fôrma cívica: higiene, moral e trabalho no projeto da Associação Brasileira de Educação (1924-1931). Bragança Paulista: Edusf, 1998.

CARVALHO, Marta Maria Chagas de. Anísio Teixeira: Itinerários. Em Seminário "Um olhar sobre Anísio". Mesa Redonda "Política Educacional", Rio de Janeiro, 3 set. 1999. Rio de Janeiro, UFRJ/CFCH/PACC, Fundação Anísio Teixeira, 1999. Texto disponível em http://www.bvanisioteixeira.ufba.br/artigos/MartaCarvalho.htm. Acessado em 12 de maio de 2017.

CARVALHO, Marta Maria Chagas de. Reformas da instrução pública. Em: LOPES, Eliane Maria Teixeira; FILHO, Luciano Mendes de Faria; VEIGA, Cynthia Greive.500 anos de Educação no Brasil. Belo Horizonte: Autêntica, 2000.

CARVALHO, Marta Maria Chagas de. A escola e a república e outros ensaios. Bragança Paulista, EDUSF, 2003.

CASTRO, Alda Maria Duarte Araújo. Gestão das Políticas Educacionais e as repercussões para o trabalho docente. Em CAVALCANTE, Marina Maria Dias; SALES, José Albio Moreira M. de; FARIAS, Isabel Maria Sabino de; LIMA, Maria Socorro Lucena. (Org.). Didática e Prática de Ensino: diálogos sobre a escola, a formação de professores e a sociedade. 1ed.Fortaleza: Eduece, 2015, v. 4, p. 1-21.

CAVALIERE, Ana Maria. Escolas de tempo integral: uma ideia forte, uma experiência frágil. Em CAVALIERE, Ana Maria e COELHO, Ligia Marta Coimbra. Educação brasileira e(m) tempo integral. Petrópolis: Vozes, 2002.

CAVALIERE, Ana Maria. Entre o pioneirismo e o impasse: a reforma paulista de 1920. In: Educação e Pesquisa, São Paulo, v.29, n.1.2003, p. 27-44, 2003

CAVALIERE, Ana Maria. Tempo de Escola e qualidade na educação pública. Educação e Sociedade, v.28, n ${ }^{\circ} 00$ p.1015-1035, 2007. 
CAVAliERE, Ana Maria. Anísio Teixeira e a educação integral. Paidéia (Ribeirão Preto), Ribeirão Preto, v. 20, n. 46, p. 249-259, 2010.

CAVALIERE, Ana Maria. Escola pública de tempo Integral no Brasil: filantropia ou política de Estado? Educação e Sociedade, v.35, n ${ }^{\circ}$ 129, p.1205-1222, 2014.

CENTRO DE ESTUDOS E PESQUISAS EM EDUCAÇÃO, CULTURA E AÇÃO COMUNITÁRIA - CENPEC. Tendências para a educação integral. São Paulo: CENPEC :Fundação Itaú Social, 2011.

CHAUÍ. Democracia e sociedade autoritária. Comunicação e Informação, v.15, n.2, p.149$161,2012$.

COELHO, Ligia Marta Coimbra da Costa. Educação integral e integralismo nos anos 30: a vez e a voz dos periódicos. In: SIMPÓSIO NACIONAL DE HISTÓRIA, 23., 2005, Londrina, Paraná. Anais. Londrina, 2005. p. 1-10. Disponível em: http://anais.anpuh.org/wpcontent/uploads/mp/pdf/ANPUH.S23.0581.pdf. Acesso em: 17 de maio de 2017.

COELHO, Lígia Marta Coimbra da Costa. História(s) da educação integral. Em Aberto, Instituto Nacional de Estudos e Pesquisas Educacionais Anísio Teixeira. Brasília Brasília, v. 22, n. 80 p. 83-96, 2009.

CORAGGIO, José Luiz. Propostas do Banco Mundial para a educação: sentido culto ou problemas de concepção? Em TOMMASI, Lívia \&WARDE Miriam Jorge \& HADDAD, Sergio. O Banco Mundial e as políticas educacionais. São Paulo: Cortez. 1996

CUNHA, Luiz Antônio. Estado, Educação e democracia no Brasil. São Paulo: Cortez, 1991.

DARDOT, Pierre. e LAVAL, Christian. A Nova Razão do Mundo - Ensaio sobre a Sociedade Neoliberal. São Paulo, Boitempo, 2016.

DUARTE, Newton. Vigotski e o "aprender a aprender". Crítica às apropriações neoliberais e pós-modernas da teoria vigotskiana. Campinas: Autores Associados, 2000.

EVANGELISTA, Olinda e SHIROMA, Eneida O. Educação para o alívio da pobreza: novo tópico da agenda global. Revista de Educação PUC Campinas, Campinas, n. 20, p. 43-54, 2006.

EVANGELISTA, Olinda e SHIROMA Eneida. Avaliação e responsabilização pelos resultados: atualizações nas formas de gestão de professores. Perspectiva, Florianópolis, v. 29, n. 1, 127-160, jan./jun. 2011.

FERRARO, Alceu Ravanello. Escolarização no Brasil na ótica da exclusão. Em MARCHESI, Álvaro; GIL, Carlos Hernández. Fracasso escolar: uma perspectiva multicultural. Porto Alegre: Artmed, 2004.

FREITAS, Cezar Ricardo de e GALTER, Maria Inalva. Reflexões sobre a educação em tempo integral no decorrer do século XX. Educere et Educare., Cascavel, v.1, n.1, p.119-123, 2007.

FREITAS, Luiz Carlos. Os reformadores empresariais da educação: da desmoralização do magistério à destruição do sistema público de educação. Educação e Sociedade Campinas, v. 33, n. 119, p. 379-404, 2012. 
FREITAS, Luiz Carlos de. Os reformadores empresariais da educação e a disputa pelo controle do processo pedagógico na escola. Educação e Sociedade. Campinas, v. 35, n. 129, 2014, p. 1085-1114, 2014.

FREITAS. Luiz Carlos de. (2015, 06 de Outubro). Mais Educação ou mais Ensino. Avaliação Educacional, acessado em 20 de julho de 2018, de https://avaliacaoeducacional.com/2015/10/06/mais-educacao-ou-mais-ensino/.

FONSECA, Marília. O Banco Mundial como referência para a justiça social no terceiro mundo: evidências do caso brasileiro. Revista da Faculdade de Educação. Universidade de São Paulo, São Paulo, v. 24, n.1, p. 37-68, 1998.

FONSECA, Marília. A experiência de cooperação entre o Brasil e o Banco Mundial: redefinindo o papel da educação e do professor. Linhas críticas, v.7 n $12,2001$.

FRIGOTTO. Gaudêncio (org.). Educação e crise do Trabalho: perspectivas de final de século. Petrópolis: Vozes, 2001.

FRIGOTTO, Gaudêncio \& CIAVATTA, Maria. Educação Básica no Brasil na década de 90: Subordinação ativa e consentida à lógica do mercado. Educação e Sociedade, v.24, n 82 , 93132, 2003.

FRIGOTTO, Gaudêncio, CIAVATTA Maria e RAMOS, Marise Nogueira. Educação Profissional e Desenvolvimento. Em UNESCO. (Org.). International Handbook of Technical and Vocational Education and Training. Bonn: UNEVOC/UNESCO, 2005, v.p. 1-14, 2005

FUNDO NACIOBAL DE DESENVOLVIMENTO DA EDUCAÇÃO. Manual de Educação Integral para obtenção de Apoio Financeiro por meio do Programa Dinheiro Direto na Escola - PDDE, no exercício de 2008. Brasília, DF: FNDE, 2008.

FUNDO NACIOBAL DE DESENVOLVIMENTO DA EDUCAÇÃO. Manual de Educação Integral para obtenção de Apoio Financeiro por meio do Programa Dinheiro Direto na Escola - PDDE, no exercício de 2009. Brasília, DF: FNDE, 2009.

FUNDO NACIOBAL DE DESENVOLVIMENTO DA EDUCAÇÃO. Manual de Educação Integral para obtenção de Apoio Financeiro por meio do Programa Dinheiro Direto na Escola - PDDE, no exercício de 2010. Brasília, DF: FNDE, 2010.

FUNDO NACIOBAL DE DESENVOLVIMENTO DA EDUCAÇÃO. Manual de Educação Integral em jornada ampliada para obtenção de Apoio Financeiro por meio do Programa Dinheiro Direto na Escola - PDDE, no exercício de 2011. Brasília, DF: FNDE, 2011.

FUNDO NACIOBAL DE DESENVOLVIMENTO DA EDUCAÇÃO. Manual operacional de Educação Integral. Brasília, DF: FNDE, 2012.

FUNDO NACIOBAL DE DESENVOLVIMENTO DA EDUCAÇÃO. Manual operacional de Educação Integral. Brasília, DF: FNDE, 2013.

FUNDO NACIOBAL DE DESENVOLVIMENTO DA EDUCAÇÃO. Manual operacional de Educação Integral. Brasília, DF: FNDE, 2014. 
FUNDO NACIOBAL DE DESENVOLVIMENTO DA EDUCAÇÃO. Resolução n ${ }^{\circ} \mathbf{d e} 14$ de Abril de 2016. Brasília, DF FNDE, 2016

FUNDAÇÃO ITAÚ SOCIAL. Relatório de Avaliação Econômica e Estudos Qualitativos. O Programa Mais Educação, 2015. Acessado em 25 de Julho de 2017, de: http://www.redeitausocialdeavaliacao.org.br/wp.

GALLO, Silvio. A educação integral numa perspectiva anarquista. Em CAVALIERE, Ana Maria e COELHO, Ligia Marta Coimbra. Educação brasileira e(m) tempo integral. Petrópolis: Vozes, 2002.

GENTILI, Pablo. Educar para o desemprego. A desintegração da promessa integradora. Em FRIGOTTO, Gaudêncio. Educação e crise do trabalho: perspectivas de final de século. Petrópolis: Vozes, 2001

GENTILI. Pablo. A falsificação do Consenso. Petrópolis: Vozes, 2002.

GENTILI, Pablo (Org). Pedagogia da exclusão. Crítica a neoliberalismo em Educação. Petrópolis: Vozes, 2005.

HADDAD, Sergio. Banco Mundial, OMC e FMI: o impacto nas políticas educacionais. São Paulo: Cortez, 2008

HÖFLING, Eloísa de Mattos. Estado e políticas (públicas) sociais. Caderno Cedes, ano XXI, n.55, Nov,2001.

KRAWCZYK, Nora Rut. O PDE: novo modo de regulação estatal? Cadernos de Pesquisa, São Paulo, v.38, n.135, p.797-815, dez. 2008.

KRUPPA, Sonia Maria Portella. O Banco Mundial e as políticas públicas educacionais no Brasil nos anos 90. Reunião anual da AMPED. Anais. Caxambu, 2001.

LAVAL, Christian. A escola não é uma empresa. Londrina: Planta, 2004.

LIBÂNEO, José Carlos. O dualismo perverso da escola pública brasileira: escola do conhecimento para os ricos, escola do acolhimento social para os pobres. Educação e Pesquisa, São Paulo, v. 38, n. 1, mar. 2012.

LIBÂNEO, José Carlos. Escola de tempo integral em questão: lugar de acolhimento social ou de ensino-aprendizagem? In: BARRA, Valdeniza M. da. (Org.). Educação: ensino, espaço e tempo na escola de tempo integral. 1ed.Goiânia: CEGRAF, 2014.

LIBÂNEO, Carlos José; OLIVEIRA, João Ferreira de e TOSCHI, Mirza Seabra. Educação Escolar Políticas, Estruturas e Organização. São Paulo: Cortez, 2015.

LIBÂNEO, José Carlos. Políticas educacionais no Brasil: desfiguramento da escola e do conhecimento escolar. Cadernos de Pesquisa (Fundação Carlos Chagas), v. 46, p. 38-62, 2016. Disponível em: http://www.scielo.br/pdf/cp/v46n159/1980-5314-cp-46-159-00038.pdf. Acesso em 20 de julho de 2017. 
LOBO JR., Dácio. Sobre as relações entre as questões da educação e do populismo. Educação e Sociedade, $n^{\circ} 24$, p. 48-60, 1986.

MIGNOT, Ana Christina. CIEP: alternativa para a qualidade de ensino ou nova investida do populismo em educação? Dissertação de mestrado, Faculdade de Educação da PUC- RJ, 1988.

MARTINS, André Silva. Todos pela Educação: O projeto educacional de empresários para o Brasil, Práxis Educativa, 4(1) 21-28,2009.

MARTINS, Erika Moreira. Movimento Todos pela Educação: um projeto de nação para a educação brasileira. Dissertação de Mestrado, Unicamp, 2013

MARX, Karl. O capital: Livro I, Capítulo VI (inédito). São Paulo: Ciências Humanas,1978.

MARX, Karl. O capital: crítica da economia política: livro I. 31. ed. São Paulo: Civilização Brasileira vol.1 $34^{\circ} \mathrm{ed} .2016$.

MAURÍCIO, Lucia Velloso. Permanência do horário integral nas escolas públicas do Rio de Janeiro: no campo e na produção escrita. Em CAVALIERE, Ana Maria e COELHO, Ligia Marta Coimbra. Educação brasileira e(m) tempo integral. Petrópolis: Vozes, 2002

MAURÍCIO, Lucia Velloso. Escritos, representações e pressupostos da escola pública de horário integral. Em Aberto, Instituto Nacional de Estudos e Pesquisas Educacionais Anísio Teixeira. Brasília, v.22, nº8, p97-108, 2009.

MOLL, Jaqueline. Um paradigma contemporâneo para a educação integral. Pátio: Revista pedagógica. Ano XII, n51, p.12 -15, 2009.

MOLL, Jaqueline (org). Caminhos da Educação Integral no Brasil: direito a outros tempos e espaços educativos. Porto Alegre: Penso, 2012

MOLL, Jaqueline e LECLERC, Gesuína de Fátima Elias. Programa Mais Educação: avanços e desafios para uma estratégia indutora da Educação Integral e em tempo integral. Educar em Revista, Curitiba, n. 45, p. 91-110, jul./set. 2012.

MORAES, Carmen Sylvia Vidigal, CALSAVARA, Tatiana e MARTINS, Ana Paula. O ensino libertário e a relação entre trabalho e educação. Educação e Pesquisa, v.38 n.04, p.997-1012, 2012.

NUNES, Clarice. Centro Educacional Carneiro Ribeiro: concepção e realização de uma experiência de educação integral no Brasil. Em Aberto, Instituto Nacional de Estudos e Pesquisas Educacionais Anísio Teixeira. Brasília. V.22, n80 p.121-136, 2009.

OFFE, Claus. Problemas estruturais do Estado capitalista. Rio de Janeiro: Tempo Brasileiro, 1984.

OCDE, Competências para o Progresso Social: $O$ poder das competências socioemocionais. Fundação Santiliana, 2015. Disponível em: http://pt.calameo.com/read/002899327e71398e4d015. Acesso em 16 de julho de 2017.

PAUlA, Ana Paula Paes de. Por uma Nova Gestão Pública. Rio de Janeiro. FGV, 2005. 
PAUlA, Ana Paula Paes de. Administração Pública Brasileira Entre o Gerencialismo e a Gestão Social. Revista de Administração de Empresas, vol.45 n¹, p.36-49, 2008

PARO, Vitor Henrique Paro et all. Escola de tempo integral: Desafio para o ensino público. São Paulo: Cortez, 1988.

PARO, Vitor Henrique. Educação integral em tempo integral: uma concepção de educação para a modernidade. Em COELHO, Lígia Martha da Costa. (Org.) Educação Integral em tempo integral: estudos e experiências. Petrópolis, FAPERJ, 2009.

PARO, Vitor Henrique. Educação como exercício do poder: crítica ao senso comum em educação. São Paulo: Cortez, 2014.

PATTO, Maria Helena Souza. Psicologia e Educação. São Paulo: T.A Queiroz, 1984

PATTO, Maria Helena Souza. "Escolas cheias, cadeias vazias" nota sobre as raízes ideológicas do pensamento educacional brasileiro. Estudos avançados, 21(61), 243-266, 2007.

PATTO, Maria Helena Souza. Mutações do cativeiro: escritos de psicologia e política. São Paulo: Hacker /Edusp, 2000.

PATTO, Maria Helena Souza. A produção do fracasso escolar. Histórias de submissão e rebeldia. São Paulo: Casa do Psicólogo, 2010.

RAVITCH, Diane. Reign of error: The Hoax of the Privatization Movement and the Danger to America's Public Schools. New York: Alfred A. Knopf, 2013.

RIBEIRO, Darcy. O livro dos CIEPs. Rio de Janeiro: Bloch Editores, 1986

ROMANELLI, Otaíza de Oliveira. História da educação no Brasil Petrópolis: Vozes, 1978.

SAVIANI, Demerval. Educação: do senso comum à consciência filosófica. São Paulo: Cortez/Autores Associados, 1985

SAVIANI, Dermeval. Escola e Democracia, São Paulo: Cortez: Autores Associados.2006.

SAVIANI, Dermeval. O Plano de Desenvolvimento da Educação: análise do projeto do MEC. Educação e Sociedade. 28 (100), 1231-1255, 2007.

SAVIANI, Demerval. História das Ideias pedagógicas no Brasil. Campinas: Autores Associados, 2011.

SAWAYA, Sandra Maria. Os relatórios internacionais e a reforma na educação: reflexos sobre a formação. International Studies on Law and Education, p.91-99, 2012.

SILVA, Luiz Inácio Lula da "Carta ao povo brasileiro". Disponível em http://www1.folha.uol.com.br/folha/brasil/ult96u33908.shtml. Acessado em 21 de julho de 2017.

SILVA, Jamerson Antonio de Almeida da \& SILVA, Katharine Ninive Pinto. Educação Integral no Brasil de hoje, Curitiba: Editora CRV, 2012. 
SILVA, Jamerson Antonio de Almeida da \& SILVA, Katharine Ninive Pinto. Analisando a concepção de educação integral do governo Lula/Dilma através do Programa Mais Educação. Educação em Revista v.30, nº1, p.95-126, 2014.

SINGER, André. (2012) Os sentidos do Lulismo: reforma gradual e pacto conservador. São Paulo: Companhia das Letras, 2012.

TORRES, Rosa Maria. Melhorar a qualidade da educação básica? As estratégias do Banco Mundial. Em TOMMASI, Lívia \&WARDE Miriam Jorge \& HADDAD, Sergio. O Banco Mundial e as políticas educacionais. São Paulo: Cortez. 1996

UNESCO. Declaração Mundial sobre educação para todos. Plano de ação para satisfazer as necessidades básicas de aprendizagem. Tailândia: CEPAL/UNESCO,1990.

UNESCO. Educação: um tesouro a descobrir. 7 ed. São Paulo: Cortez, 1999.

UNICEF. Tendências para a educação integral. "Iniciativa: Fundação Itaú Social, Fundo das Nações Unidas para a Infância” (UNICEF). São Paulo: Fundação Itaú Social - CENPEC, 2011. 